\title{
PRÁTICA PEDAGÓGICA REFLEXIVA DE LICENCIANDOS DE ENFERMAGEM: O PORTFÓLIO COMO INSTRUMENTO
}

Dissertação apresentada ao Programa de Pós-Graduação em Gerenciamento em Enfermagem da Escola de Enfermagem da Universidade de São Paulo para obtenção do título de Mestra em Ciências.

Área de Concentração: Fundamentos e Práticas de Gerenciamento em Enfermagem e em Saúde.

Orientadora: Prof ${ }^{a}$ Dr ${ }^{a}$ Cláudia Prado

SÃO PAULO

2013 
AUTORIZO A REPRODUÇÃO E DIVULGAÇÃO TOTAL OU PARCIAL DESTE TRABALHO, POR QUALQUER MEIO CONVENCIONAL OU ELETRÔNICO, PARA FINS DE ESTUDO E PESQUISA, DESDE QUE CITADA A FONTE.

Assinatura:

Data:

Vaz, Débora Rodrigues

Prática pedagógica reflexiva de licenciandos de enfermagem: o portfólio como instrumento / Débora Rodrigues Vaz . -- São Paulo, 2013.

$152 \mathrm{p}$.

Dissertação (Mestrado) - Escola de Enfermagem da Universidade de São Paulo.

Orientadora: Prof $^{a}$ Dr $^{a}$ Cláudia Prado

Área de concentração: Fundamentos e práticas de gerenciamento em enfermagem e em saúde

1. Enfermagem - Educação 2. Licenciatura 3. Estágios supervisionados 4. Narrativas 5.Portfólios I. Título. 
Nome: Débora Rodrigues Vaz

Título: Prática pedagógica reflexiva de licenciandos de Enfermagem: o portfólio como instrumento.

Dissertação apresentada ao Programa de Pós-Graduação em Gerenciamento em Enfermagem da Escola de Enfermagem da Universidade de São Paulo para obtenção do título de Mestra em Ciências.

Aprovado em:

\section{Banca Examinadora}

Prof. Dr. Instituição:

Julgamento: Assinatura:

Prof. Dr. Instituição: Julgamento: Assinatura:

Prof. Dr. Instituição: Julgamento: Assinatura: 

Dedico este trabalho

Aos meus pais Áurea e Eduardo e ao meu tio José Carlos que me incentivaram e me apoiaram na continuidade dos meus estudos.

À irmã Flávia e sobrinha Maria Eduarda, que compreenderam minhas ausências.

Ao Ayrton com quem tenho compartilhado os bons momentos da vida.

A todos os professores. 



\section{AGRADECIMENTO ESPECIAL}

Não há educação sem amor. O amor implica luta contra o egoísmo. Quem não é capaz de amar os seres inacabados não pode educar. Não há educação imposta, como não há amor imposto.

Quem não ama não compreende o próximo, não o respeita.

(Paulo Freire)

À querida Professora Cláudia Prado...

Se cheguei até aqui foi porque me incentivou, acreditou e me fez acreditar que eu era capaz. Com seu amor me acolheu e me ensinou, me fez uma pessoa melhor. Compartilhou meu riso e entendeu minhas lágrimas. Sempre tão pronta, tão disposta, tão alegre. Que você possa sempre colher os frutos de sua dedicação.

Feliz daquele que pode compartilhar sua companhia!

Obrigada por tudo! 



\section{AGRADECIMENTOS}

À Deus por me guiar e me dar saúde nesta caminhada

Ao Ayrton que sempre me incentivou e me fez acreditar que eu era capaz, que me fortalece a cada dia com seu amor e carinho.

Aos meus pais Áurea e Eduardo e a todos os meus familiares pelo apoio e compreensão.

Aos meus sogros, Thaís e Helyon, com quem pude contar sempre.

Aos amigos Sara e Carlos, que compreenderam minha ausência e sempre torceram por mim.

À Denise Almeida, amiga e companheira de trabalho, de mestrado, de sonhos, de compras, de risadas e de lágrimas, que me inspirou a querer ser uma profissional competente e com quem aprendi que a docência se faz com amor e dedicação.

À Profa Marina Peduzzi por me receber em seu grupo de pesquisa, por compartilhar seu conhecimento e me incentivar a iniciar o mestrado.

À Prof ${ }^{a}$ Maria Madalena Januário Leite, minha primeira orientadora no mestrado, por me acolher, me acompanhar e orientar nos primeiros passos.

À Prof ${ }^{a}$ Vilanice Alves de Araújo Püschel pelas valiosas contribuições no Exame de Qualificação, pela gentileza e disponibilidade.

Aos meus professores do mestrado pelos ensinamentos e contribuições.

Aos colaboradores da EEUSP e Biblioteca pela prontidão e apoio.

Aos Dirigentes, docentes e demais colaboradores da Escola de Enfermagem São Joaquim - Cleide, Elza, Arlete, Eide, Fátima, Juliana, Marlene, Nilza, Valéria e Mariele pela convivência prazerosa, pelo apoio, incentivo e torcida.

Às também colegas de trabalho Thaís, Gladimara, Tereza, Gilmara e Margareth, pela convivência mais próxima, pelos ombros amigos, por me escutarem e me incentivarem, pela força nos momentos difíceis, pelos bons momentos dentro e fora do trabalho e lógico, pelas risadas. 
À Chefe do Departamento de Enfermagem do Hospital Beneficência Portuguesa, Denise Alves Santini, por incentivar o aprimoramento de seus colaboradores.

Aos meus alunos com quem aprendo a cada dia.

E a todos aqueles que contribuíram, de alguma forma, para a concretização deste trabalho.

Obrigada!!! 
Vaz, D. R. Prática pedagógica reflexiva de licenciandos de Enfermagem: o portfólio como instrumento. [dissertação]. São Paulo: Escola de Enfermagem, Universidade de São Paulo; 2013.

\section{RESUMO}

Introdução: Os estágios curriculares supervisionados dos cursos de licenciatura são oportunidades que permitem aos professores em formação, refletirem sobre sua prática, ajudando-os na construção de um conhecimento pedagógico, que o embasará ao longo de sua vida profissional. Neste contexto é esperado que os licenciandos desenvolvam reflexões que transponham o nível descritivo, para que sejam levados a um olhar crítico sobre seu desempenho, com o objetivo de transformar a sua prática pedagógica. As narrativas construídas através da elaboração de portfólios reflexivos apresentam-se como estratégias potencializadoras para o desenvolvimento de práticas reflexivas. Objetivo: Este estudo teve como objetivo analisar, quanto aos níveis de reflexão, as narrativas relacionadas à prática pedagógica vivenciada durante o estágio curricular supervisionado relatadas nos portfólios de licenciandos de Enfermagem. Método: Trata-se de um estudo documental exploratório-descritivo. Foram analisados os portfólios dos estudantes do curso de Licenciatura em Enfermagem de uma universidade pública de São Paulo. O portfólio foi desenvolvido no estágio curricular supervisionado que é integrado à disciplina ENO 436 - Metodologia de ensino de Enfermagem II, em 2011. A disciplina, que tem como foco as bases teórico-metodológicas e práticas para a formação do professor, propôs uma Rota de Aprendizagem constituída por oito atividades para a elaboração do portfólio, das quais duas foram analisadas: "Descrição reflexiva da aula teórica ministrada" e "Descrição reflexiva da supervisão em campo de prática". Resultados: A turma analisada era composta por 43 estudantes, sendo que somente 28 completaram as duas atividades descritas em seus portfólios. Na primeira atividade, dos 28 portfólios analisados, todos apresentaram narrativas em nível 
técnico de reflexão, 22 em nível crítico e 15 em nível metacrítico e na segunda atividade, todos os portfólios apresentaram narrativas em nível técnico, 21 em nível crítico e 16 em nível metacrítico. Os fatos narrados por todos os licenciandos aconteceram em diversas escolas e instituições de saúde, sob a supervisão de diferentes professores supervisores, onde cada licenciando enfatizou em suas narrativas o que the foi mais significativo. Conclusões: $O$ portfólio proporcionou 0 desenvolvimento dos três níveis de reflexão propostos por Sá-Chaves (2000), técnico, crítico e metacrítico, porém nem todos os licenciandos alcançaram o nível crítico e metacrítico. Os estudantes tiveram oportunidade de vivenciar a prática pedagógica e muitos apresentaram reflexões em nível metacrítico, refletindo sobre seu desempenho, sobre a construção da sua identidade docente e sobre a importância de refletir sobre a prática com o objetivo de transformá-la e transformar-se a si mesmo. O portfólio representou um espaço significativo para a reflexão dos licenciandos sobre a prática vivenciada no campo de estágio bem como uma ferramenta relevante para os professores na medida em que estes, a partir desses resultados, poderão reiterar e reestruturar a proposta do uso do portfólio no Curso de Licenciatura em Enfermagem.

PALAVRAS-CHAVE: Enfermagem - Educação. Licenciatura. Estágios supervisionados. Narrativas. Portfólios. 
Vaz, D. R. Reflexive pedagogical practice of undergraduates in Nursing: the portfolio as instrument [dissertation]. São Paulo: School of Nursing, University of São Paulo; 2013.

\section{ABSTRACT}

Introduction: The supervised training program of the degree courses are opportunities that allow to the teachers in formation think about their practice, helping them in the construction of a pedagogical knowledge that will base them along their professional life. In this context, it is waited that the undergraduates develop reflections to transpose the descriptive level, so that they are taken to a critical view on their acting, with the objective of transforming their pedagogical practice. The narratives built through the elaboration of reflexive portfolios present as potentiated strategies for the development of reflexive practices. Objective: This study had as objective analyzes, as for the reflection levels, the narratives related to the pedagogical practice experienced during the supervised training program reported in the portfolios of the Nursing undergraduates. Method: It is an exploratory-descriptive documental study where were analyzed the portfolios of the undergraduates of Nursing degree in a public university in São Paulo. The portfolio was developed in the supervised training program that is integrated into the discipline Nursing Teaching Methodology II (ENO 436), in 2011. The discipline, that focuses the theoretical-methodological and practical bases for the formation of the teacher proposed a Route of Learning constituted by eight activities for the elaboration of the portfolio, of which two were analyzed: "Reflexive description of the theoretical class taught" and "Reflexive description of the supervision in the practical field". Results: The analyzed group was composed by 43 students, and only 28 completed the two activities described in their portfolios. In the first activity, of the 28 portfolios analyzed, all presented narratives in technical level of reflection, 22 in critical level and 15 in level metacritical and in the second activity, all of the 
portfolios presented narratives in technical level, 21 in critical level and 16 in level metacritical. The facts narrated by all of the undergraduates happened in several schools and institutions of health, under the supervision of different supervising teachers, where each undergraduate emphasized in their narratives what was more significant. Conclusions: The portfolio provided the development of the three reflection levels proposed by Sá-Chaves (2000), technician, critic and metacritical, however not all of the undergraduates reached the critical and metacritical level. The students had opportunity to experience the pedagogical practice and many ones presented reflections in the metacritical level, thinking about their acting, about the construction of their teaching identity and on the importance of contemplating on the practice with the objective of transforming it as well as themselves. The portfolio represented a significant space for the reflection of the undergraduates on the practice experienced in the training field as well as a relevant tool for the teachers, in so far these ones, from those results, can reiterate and restructure the proposal of the use of the portfolio in the Nursing degree.

KEY-WORDS: Nursing - Education. Degree course. Supervised training. Narratives. Portfolios. 


\section{LISTA DE ILUSTRAÇÕES}

Figura 1 - Processo de Reflexão para Schön....................................37

Figura 2 - Nível Técnico de Lógica Reflexiva ................................. 43

Figura 3 - Nível Crítico de Lógica Reflexiva ................................... 44

Figura 4 - Nível Metacrítico de Lógica Reflexiva .............................. 46

Figura 5 - Aula - Portfólio Educacional - Moodle ............................ 72

Figura 6 - Atividade "Descrição Reflexiva da aula teórica ministrada" .

Figura 7 - Atividade "Descrição Reflexiva da supervisão em campo

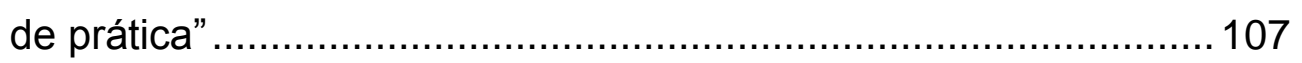




\section{LISTA DE GRÁFICOS}

Gráfico 1 - Níveis de Reflexão - Atividade "Descrição Reflexiva da aula teórica ministrada ................................................................ 83

Gráfico 2 - Níveis de Reflexão - Atividade "Descrição reflexiva da supervisão em campo de prática 108 


\section{SUMÁRIO}

APRESENTAÇÃO

1 INTRODUÇÃO

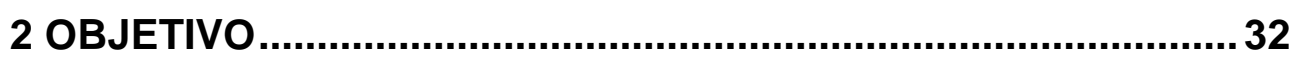

3 REFERENCIAL TEÓRICO .....................................................34

3.1 FORMANDO PROFESSORES REFLEXIVOS .......................34

3.2 NÍVEIS DE LÓGICA REFLEXIVA........................................ 42

3.2.1 Nível Técnico de Lógica Reflexiva ................................ 43

3.2.2 Nível Crítico de Lógica Reflexiva................................... 44

3.2.3 Nível Metacrítico de Lógica Reflexiva............................ 45

4 O ESTÁGIOCURRICULAR PROFISSIONAL E A FORMAÇÃO DOCENTE ............................................................................. 48

5 ESTRATÉGIAS PARA FORMAÇÃO REFLEXIVA ......................54

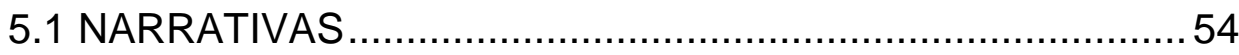

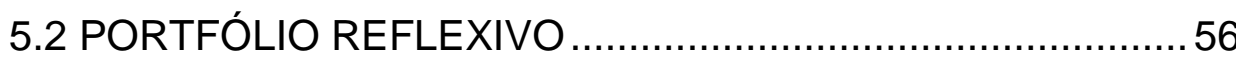

6 O PORTFÓLIO NA ESCOLA DE ENFERMAGEM DA USP .........66

7 PROCEDIMENTO METODOLÓGICO..........................................76

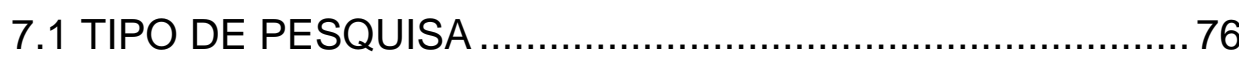

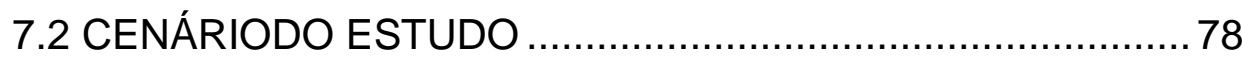

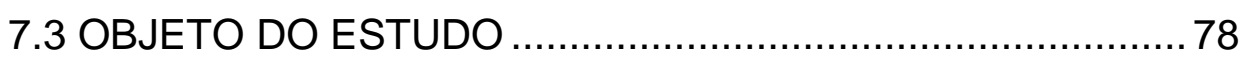

7.4 PROCEDIMENTO DE COLETA DE DADOS..........................78

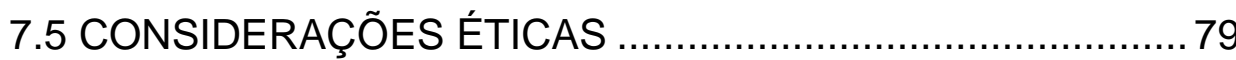

8 APRESENTAÇÃO E DISCUSSÃO DOS RESULTADOS ..............82

8.1 ATIVIDADE "DESCRIÇÃO REFLEXIVA DA AULA TEÓRICA

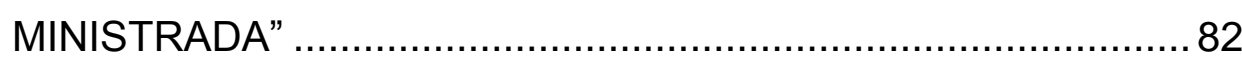

8.1.1 As Narrativas em Nível Técnico .................................. 84

8.1.2 As Narrativas em Nível Crítico ....................................95

8.1.3 As Narrativas em Nível Metacrítico .............................103 8.2 ATIVIDADE "DESCRIÇÃO REFLEXIVA DA SUPERVISÃO EM

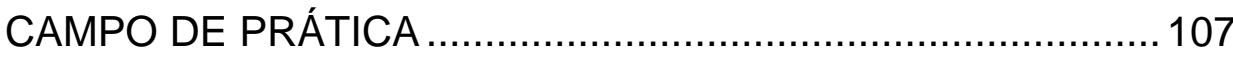

8.2.1 As Narrativas em Nível Técnico .................................. 108

8.2.2 As Narrativas em Nível Crítico ....................................116

8.2.3 As Narrativas em Nível Metacrítico .............................121 
9 CONCLUSÕES...................................................................... 128

10 CONSIDERAÇÕES FINAIS................................................. 132

REFERÊNCIAS ........................................................................ 136

APÊNDICES ........................................................................... 146

ANEXOS............................................................................. 150 
APRESENTAÇÃO 


\section{APRESENTAÇÃO}

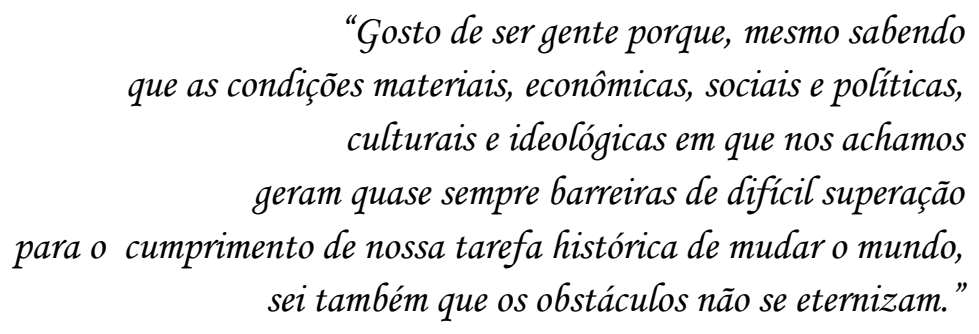

(Paulo Freire)

Graduada em Enfermagem pela Faculdade de Enfermagem do Hospital Israelita Albert Einstein, em 1995, trabalhei muitos anos na assistência em unidade de internação e UTI pediátrica no Hospital Beneficência Portuguesa de São Paulo.

Em 2003 tive a oportunidade de iniciar meu trabalho como docente na educação profissional de nível técnico em Enfermagem, curso oferecido na mesma instituição, o que me aproximou das metodologias ativas e do uso do portfólio. A necessidade de me atualizar e me preparar e a paixão pela docência, me fizeram investir em minha formação na área da educação e cursei Licenciatura em Enfermagem e em Pedagogia, onde aprofundei meus conhecimentos sobre Portfólio Reflexivo.

Interessada também no Ensino a Distância, realizei especialização na área a aprofundei meus conhecimentos sobre portfólio, porém agora dentro de Ambientes Virtuais de Aprendizagem (AVA).

Sentindo a necessidade de continuar minha formação acadêmica e realizar mestrado na área de Enfermagem, ingressei no GEPETE EEUSP (Grupo de Estudos e Pesquisas de Tecnologia da Informação nos Processos de Trabalho em Enfermagem da Escola de Enfermagem da Universidade de São Paulo) e, percebendo a 
utilização crescente do uso do portfólio nos cursos de Enfermagem, decidi continuar pesquisando sobre o tema.

Um dos projetos desenvolvidos pelo grupo apresentava íntima relação com o curso de Licenciatura em Enfermagem da USP, utilizando AVA em duas disciplinas. A partir daí pude participar na elaboração, implementação e mediação de aulas virtuais para a Licenciatura, que envolveram como um dos temas o uso do portfólio.

O curso de Licenciatura em Enfermagem da Escola de Enfermagem da USP - EEUSP apresenta grande preocupação com a formação de docentes capazes de refletirem e transformarem sua prática. $E$ foi a partir de tais preocupações que o uso do portfólio como instrumento de avaliação do estágio curricular supervisionado foi adotado.

Com a utilização dos portfólios na Licenciatura, algumas dificuldades que já haviam aparecido na educação profissional de nível técnico, se intensificaram. Trabalhando com o portfólio reflexivo, precisava identificar se o estudante estava refletindo sobre os fatos narrados, o que me fez sentir a necessidade de aprofundar meus conhecimentos sobre reflexão, seus níveis e como identificá-los.

Nesse contexto, embasada nas inquietações que surgiram da utilização dos portfólios na Licenciatura e sobre a sua capacidade em estimular a reflexão crítica nos futuros docentes, nasceu a atual pesquisa que tem como perguntas: o portfólio torna-se um espaço para a reflexão sobre a prática pedagógica vivenciada no estágio curricular supervisionado do curso de licenciatura em Enfermagem? Como identificar se o licenciando está refletindo sobre a prática pedagógica vivenciada no estágio curricular supervisionado?

Dessa forma, este estudo busca analisar, quanto aos níveis de reflexão, as narrativas relacionadas à prática pedagógica vivenciada 
durante o estágio curricular supervisionado e relatadas nos portfólios dos licenciandos. 
1 INTRODUÇÃO 


\section{INTRODUÇÃO}

A Enfermagem e as profissões da saúde têm enfrentado o grande desafio de formar profissionais compromissados com a sociedade e suas necessidades de saúde, tentando articular cada vez mais o mundo do ensino com o mundo do trabalho.

A exigência crescente pela formação de profissionais autônomos, críticos-reflexivos e com habilidades para a resolução de problemas, tem conferido à formação de professores grande destaque na educação brasileira. Para Libâneo (2002, p. 7):

O tema da formação de professores assume no Brasil de hoje, importância crucial [...] não há reforma educacional, não há proposta pedagógica sem professores, já que são os profissionais mais diretamente envolvidos com os processos e resultados da aprendizagem.

As exigências do mercado de trabalho em consonância com as Diretrizes Curriculares Nacionais do curso de graduação em Enfermagem e a Lei de Diretrizes e Bases da Educação Nacional (LDB), têm levado profissionais da saúde e da educação a investirem em projetos que contribuam para a formação de docentes com competências para atuar de forma crítico-reflexiva e responsável na educação profissional de nível técnico em Enfermagem.

A educação profissional de nível técnico em Enfermagem compreende a Qualificação em Auxiliar de Enfermagem e a Habilitação em Técnico de Enfermagem, categorias profissionais reconhecidas pela Lei do Exercício Profissional de Enfermagem № 7.498/86 (COFEN, 1986), cuja formação é regulamentada pelas Diretrizes Curriculares Nacionais para a Educação Profissional de Nível Técnico - Resolução CNE/CEB 04/99 (Brasil, 1999).

Essas diretrizes trazem uma perspectiva de formação ampliada que ultrapassa o foco procedimental, envolvendo ações de cuidado 
voltadas aos aspectos biopsicossociais da prática em Saúde e o desenvolvimento de processos de trabalho em equipe multiprofissional, exigindo uma nova proposta de formação. Assim deverão ser incluídos nas propostas pedagógicas, conteúdos que permitam a compreensão do processo saúde-doença-cuidado pela determinação social da doença, promovendo a articulação entre esses conteúdos, entre teoria e prática e ampliando os espaços de prática para além do hospital (Corrêa et al., 2011, p. 78).

As competências profissionais dos auxiliares e técnicos em Enfermagem representam um dos componentes fundamentais para a qualidade da assistência preconizada pelo Sistema Único de Saúde - SUS, uma vez que esses profissionais compõem o maior contingente no cuidado em saúde e assumem a linha de frente do atendimento, necessitando assim de uma formação competente e desenvolvimento de habilidades para efetivar uma assistência com qualidade, cabendo ao enfermeiro/docente que atua neste nível de ensino, desenvolver competências em sua formação, para encontrar subsídios à sua atuação no ensino em Enfermagem, tendo como base os saberes e o saber-fazer, precedidos pelo saber-ser (Valente, Viana, 2006).

Esta nova proposta de formação exige, entre outros aspectos, a atuação de um docente que vá além da operacionalização de técnicas de ensino e do repasse de conteúdos de natureza procedimental, "que seja capaz de reconhecer-se como um ator social, comprometido com as atuais políticas públicas de Saúde e de Educação, e de reconhecer o SUS para além de um grande empregador, mas como conquista social" (Corrêa et al., 2011, p. 79).

Ser docente, nesta nova perspectiva, pressupõe "mais do que domínio dos conhecimentos específicos em torno dos quais deverá agir", exige a plena compreensão das questões envolvidas em seu trabalho, identificando-as e resolvendo-as de forma autônoma e 
responsabilizando-se pelas decisões tomadas. Significa, portanto, uma capacidade e atitude crítica que permita ao docente avaliar seu trabalho, suas opções e suas decisões (Lobo Neto, 2002, p. 7).

O Decreto № 2.208/1997, em seu artigo 9, dispõe que as disciplinas do currículo da educação profissional de nível técnico deverão ser ministradas por professores, instrutores e monitores selecionados, principalmente em função de sua experiência profissional, que deverão ser preparados para o magistério (previamente ou em serviço), mediante cursos regulares de licenciatura ou de programas especiais de formação pedagógica (Brasil, 1997).

A obrigatoriedade de formação docente para a educação profissional de nível técnico em Enfermagem foi determinada em 1968, pelo Parecer no 837/68 da Câmara de Ensino Superior, instituindo o Curso de Licenciatura em Enfermagem e concedendo o título de licenciado ao Enfermeiro. A criação do curso de Licenciatura em Enfermagem apresentou como principais justificativas a existência de cursos destinados à formação de Auxiliares de enfermagem em nível médio e a inclusão, nos currículos do ensino médio, de estudos de Enfermagem com disciplinas ou Práticas educativas (Motta, Almeida, 2003).

Assim, com a criação do curso de Licenciatura em Enfermagem, e em respeito à legislação vigente, "torna-se obrigatório que o ensino, a direção ou coordenação dos cursos de auxiliar e técnico em Enfermagem, seja de responsabilidade do enfermeiro com formação pedagógica" (Valente, 2005, p. 47).

O licenciando em Enfermagem deve possuir o diploma de enfermeiro como pré-requisito para a docência nesta área, configurando uma exceção entre as licenciaturas. Tal exigência respalda-se na regulamentação do exercício profissional pelo Conselho Federal de Enfermagem (COFEN) e Conselhos Regionais 
de Enfermagem (COREN), que juntos constituem uma autarquia vinculada ao Ministério do Trabalho.

As Diretrizes Curriculares Nacionais para a Formação de Professores da Educação Básica, em nível superior, curso de graduação e de licenciatura plena (Resolução CNE/CP1, de 18/02/2002 e CNE/CP2 de 19/02/2002 - Brasil, 2002) estabelecem, entre outras orientações inerentes à formação para a atividade docente, o preparo para: o ensino visando à aprendizagem do aluno; o acolhimento e o trato da diversidade; o exercício de atividades de enriquecimento cultural; o aprimoramento em práticas investigativas; a elaboração e a execução de projetos de desenvolvimento dos conteúdos curriculares; o uso de tecnologia da informação e da comunicação; o uso de metodologias, estratégias e materiais de apoio inovadores; o desenvolvimento de hábitos de colaboração e de trabalho em equipe.

Tais Diretrizes orientam quanto às competências desejadas à formação do professor da educação básica, porém o enfermeiro não tendo mais oportunidade de lecionar nesse âmbito, deve ser considerada também a Resolução CNE ㄲo2, de 26/06/1997, que dispõe sobre os programas especiais de formação pedagógica de docentes para as disciplinas do currículo do ensino fundamental, do ensino médio e da educação profissional de ensino médio.

De acordo com o Parecer CNE/CP 09/2001, a Licenciatura consolida-se como um curso autônomo, que ganha identidade, integralidade e terminalidade própria, separando-se do Bacharelado. A formação do professor passa a ser valorizada, deixando de ser vista como uma formação complementar e acessória, requerendo um patamar mínimo de horas para as atividades previstas (Valente, 2005). 
O tempo mínimo estabelecido para o curso de formação de docentes para atuação na educação básica (onde está inserido o ensino de nível médio em Enfermagem) será de 2400 horas de trabalho para execução de atividades acadêmicas, somadas a 400 horas de prática como componente curricular supervisionado, compondo um total mínimo de $\mathbf{2 8 0 0}$ horas, não podendo ser realizado em tempo inferior a 3 anos de formação para todos os cursos de Licenciatura, inclusive a Licenciatura em Enfermagem (Valente, 2005).

A carga horária estabelecida deve estar de tal forma organizada, que permita a articulação entre teoria e prática, buscando formar um profissional competente, flexível e que vivencie o ser docente desde o início da sua formação (Motta, Almeida, 2003).

O Parecer ํo 837/68, aprovado em 6 de dezembro de 1968 (Proc.995/68-CFE) estabelece os artigos que se seguem:

Art.10. O diplomado em curso superior de Enfermagem, parte geral que receber em estudos regulares a formação pedagógica prescrita para os cursos de licenciatura fará jus ao título e ao comprovante de licenciado em Enfermagem.

Parágrafo Único. A formação pedagógica da licenciatura de Enfermagem, na hipótese desse artigo, será feita no mesmo ou em outro estabelecimento, desde que legalmente reconhecido para tanto, e poderá também desenvolver-se paralelamente ao curso de graduação mediante acréscimo das horas - aulas correspondentes.

Art.2o. O licenciado em Enfermagem obterá registro definitivo para o ensino, na escola de segundo grau, das disciplinas e práticas educativas relacionadas com essa especialidade, inclusive Higiene.

Para Valente (2005, p. 9),

O curso de Licenciatura em Enfermagem, ao lado de Programas de Formação Pedagógica, como cursos de Especialização, levarão o Enfermeiro ao desenvolvimento das competências necessárias para 0 ensino de nível médio, à medida que os instrumentalizar para trabalhar de maneira interdisciplinar, acoplando os conhecimentos específicos que adquiriu no curso de Graduação, aos conhecimentos didáticos-pedagógicos relacionados ao ensino, favorecendo aos alunos a compreensão das relações entre as várias áreas do conhecimento. 
O docente, além de possuir um amplo conhecimento pedagógico e político, deve atuar como profissional comprometido com a educação, contribuindo para a formação de cidadãos críticos e reflexivos, capazes de lutar por uma sociedade mais democrática e mais justa (Schön, 2000; Nóvoa, 1992).

É desejável que o docente inicie o processo de desenvolvimento de sua capacidade de reflexão sobre a prática durante a sua formação, porém, é importante lembrar que: "a formação inicial não deve ser tomada como momento primeiro e último da formação profissional, já que inúmeros saberes produzidos a todo instante tornam a atualização imprescindível". São necessárias "ações que instrumentalizem o professor para continuar o desenvolvimento da formação profissional, para o que se defende uma prática formativa continuada e em serviço que articule a formação reflexiva do professor" (Nadal, 2005, p. 124). 
2 OBJETIVO 


\section{OBJETIVO}

Analisar, quanto aos níveis de reflexão, as narrativas relacionadas à prática pedagógica vivenciada durante 0 estágio curricular supervisionado relatadas nos portfólios dos licenciandos. 
3 REFERENCIAL TEÓRICO 


\section{REFERENCIAL TEÓRICO}

\subsection{FORMANDO PROFESSORES REFLEXIVOS.}

Nas últimas décadas, o termo "ensino reflexivo", tem sido adotado por professores, educadores de professores e pesquisadores educacionais de todo o mundo, num movimento contra um modelo de transmissão da educação, no qual ensinar é dizer e aprender é absorver. Esse movimento internacional que se desenvolveu na formação de professores, tendo como foco a reflexão, pode ser encarado como uma reação contra a visão de educador somente como um técnico, como um executor e contra a aceitação de formas verticalizadas de reforma educacional, que envolvem os professores apenas como participantes passivos (Zeichner, 2003, p. 41).

Para Abrantes (2005, p. 5)

O que resta do professor executor de ordens e aplicador de normas está em vias de extinção e não se vislumbra outra saída para lidar com a imprevisibilidade e a incerteza, que não seja pela via da reflexão, da tomada de decisão esclarecida, pela via do diálogo e do questionamento.

Para formar professores com tais competências, é preciso ter em mente a importância de colocá-los no foco da transformação da educação, iniciando pelo seu desenvolvimento, conforme Tavares (2002 apud Abrantes, 2005, p. 6)

\footnotetext{
em qualquer Sistema Educativo os professores são sempre 0 recurso educativo mais estratégico, ultrapassando em importância outros meios bem necessários, tais como, certas condições materiais ou sociais, consequentemente não é possível reformar a educação sem motivar, mobilizar e melhorar o potencial dos nossos professores desde o nível pré-escolar ao Ensino Superior.
}

Segundo Nóvoa (1992, p. 28) "a formação passa pela experimentação, pela inovação, pelo ensaio de novos modos de trabalho pedagógico e por uma reflexão crítica sobre a sua utilização", por processos de investigação que estejam diretamente 
articulados com as práticas educativas. As vivências da prática proporcionarão ao professor refletir sobre as possíveis mudanças, indicando que a formação acontece em diversos momentos, tanto formais como informais.

Essa nova perspectiva de formação de professores tem seus alicerces fundamentados nas publicações de Donald Schön. De acordo com Alarcão (1996 p. 11) a obra de Schön enfoca a formação do profissional reflexivo e volta-se a três temas muito atuais: o conceito de profissional que tem de ser eficiente e a quem se pedem contas; a relação entre teoria e a prática; e finalmente, a reflexão e a educação para a reflexão. Schön, que teve uma formação de base filosófica, tem seu trabalho influenciado por John Dewey.

Partindo do princípio que "a escola devia surgir como um prolongamento da vida e, ao mesmo tempo, esta devia ser destinatária das aprendizagens escolares adquiridas", Dewey, opondo-se à organização curricular por disciplinas, propôs um programa aberto, funcionando como instrumento capaz de coordenar projetos de atividades concebidos para atingir a resolução de situações problemáticas quotidianas (Lalanda, Abrantes, 1996).

$\mathrm{Na}$ concepção de Dewey, a educação deve ser pautada não somente por princípios intelectualistas, mas também por princípios prático-operacionais. Sendo assim a escola deverá favorecer a integração do conhecer com o fazer, deverá valorizar as atividades práticas em interação com as intelectuais e deverá ser organizada de maneira democrática, favorecendo a atividade livre e cooperadora (Bausola, 2004, p. 471).

Em sua obra Como pensamos, Dewey (1959 apud Giovanni, 2005, p. 51) define reflexão como "uma série lógica de ideias, de modo que cada uma engendra a seguinte com sua consequência natural e, ao 
mesmo tempo, articula-se com a ideia precedente". Para ele a capacidade para o "ato de pensar reflexivo" é que nos leva a emancipação da "ação unicamente impulsiva e rotineira". É o confrontamento com situações de difícil resolução, que inicia o processo de reflexão, fazendo com que o indivíduo analise suas experiências anteriores em busca de solução.

Para Dewey (1959 apud Giovanni, 2005, p. 52), o pensar reflexivo abrange: "10 - um estado de dúvida, hesitação, perplexidade, dificuldade mental, o qual origina 0 ato de pensar; e $2^{\circ}$ - um ato de pesquisa, procura, inquirição, para encontrar material que resolva a dúvida, assente e esclareça a perplexidade".

Schön, em sua obra Educando o profissional reflexivo, sintetiza o seu pensamento pedagógico ao defender que a formação do futuro profissional inclua um forte componente de reflexão a partir de situações práticas reais. Para ele, este é o caminho para um profissional se sentir capaz de enfrentar as novas e diferentes situações com as quais irá se deparar na vida real e de tomar as decisões apropriadas (Alarcão, 1996, p. 11).

Para Schön (2000, p. 29) os bons profissionais possuem uma prática, um saber-fazer que muito se aproxima a uma sensibilidade artística, a que ele chama "talento artístico profissional". Trata-se de tipos de "competência que os profissionais demonstram em certas situações da prática que são únicas, incertas e conflituosas".

Esta competência, que permite ao profissional agir no indeterminado, tem como base um conhecimento tácito que nem sempre pode ser descrito, mas que está presente na sua atuação mesmo que não tenha sido pensado previamente. Trata-se de um conhecimento inerente e simultâneo às suas ações e que completa o conhecimento proveniente da ciência e das técnicas (Alarcão, 1996, p. 16). 
Para Dewey, esta competência é criativa, pois leva ao desenvolvimento de novas formas de utilizar competências que já se possuem, traduzindo-se na aquisição de novos saberes (Alarcão, 1996, p. 16).

Os processos de reconhecimento e apreciação podem, muitas vezes, levar a julgamentos formativos. "No próprio ato através do qual reconhecemos algo, também percebemos esse algo como 'certo' ou 'errado'." Tal capacidade parece estar relacionada à maneira como aprendemos novas habilidades (Schön, 2000, p. 30). Neste contexto Schön propõe noções fundamentais as quais denomina: "conhecer na ação", "reflexão na ação", "reflexão sobre a ação" e "reflexão sobre a reflexão na ação" (Figura 1).

Figura 1 - Processo de Reflexão para Schön

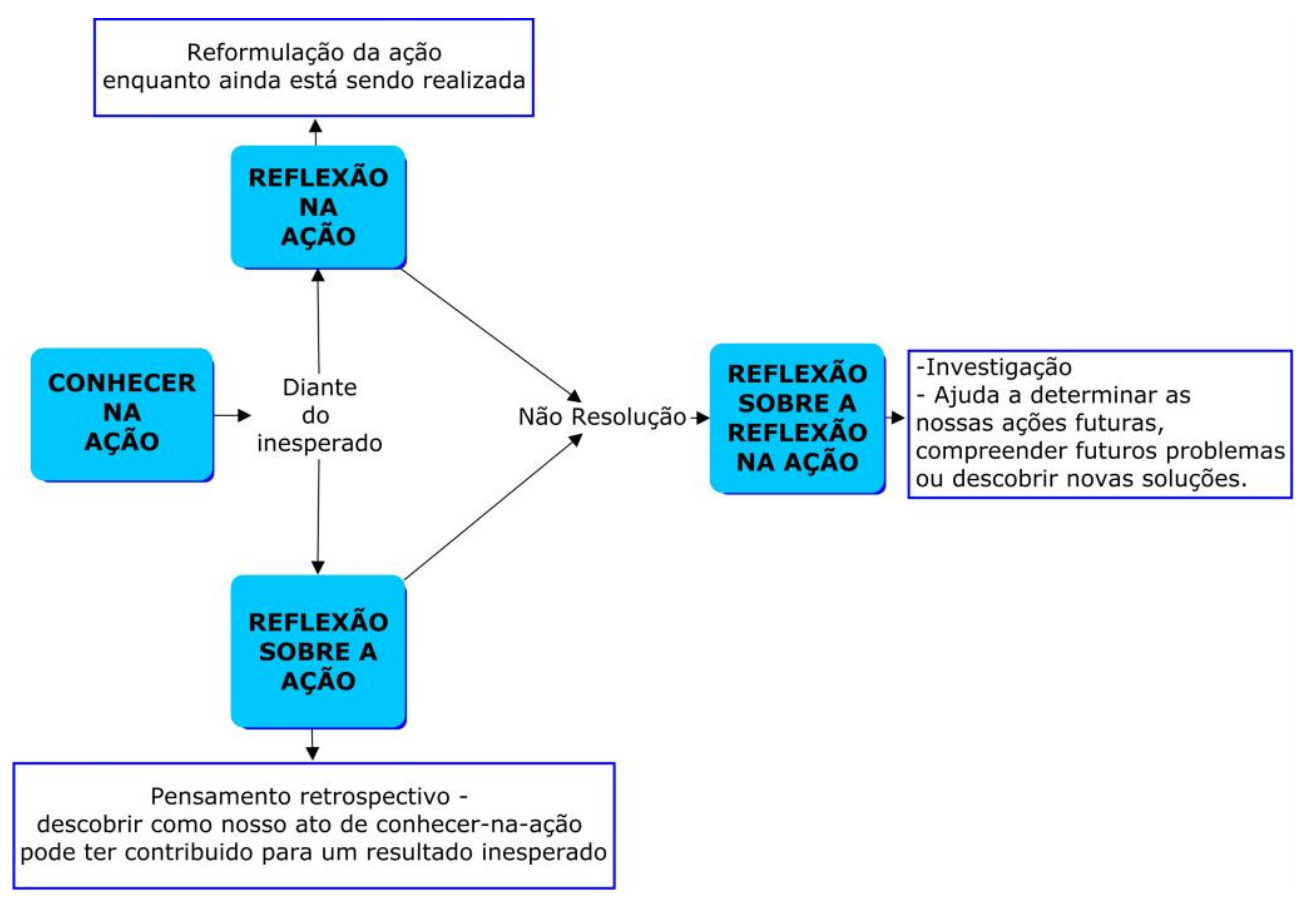

Autor: Débora Rodrigues Vaz 
O "conhecer na ação" refere-se ao conhecimento que os profissionais demonstram ao executar uma ação; a inteligência manifestada num know-how. Geralmente é difícil para o profissional falar desse conhecimento, descrevê-lo. É o que acontece quando nos auto-observamos, quando refletimos sobre nossas ações e tentamos "descrever o conhecimento tácito que lhe está subjacente" (Alarcão, 1996, p. 16).

Schön (2000, p. 31) utiliza a expressão quando refere-se aos tipos de conhecimento que revelamos em nossas ações inteligentes, por exemplo performances físicas como andar de bicicleta. $O$ ato de conhecer está na ação. "Nós o revelamos pela nossa execução capacitada e espontânea da performance, e é uma característica nossa sermos incapazes de torná-la explícita".

Para Schön (2000, p. 32) "conhecer sugere a qualidade dinâmica de conhecer-na-ação, a qual, quando descrevemos, convertemos em conhecimento-na-ação".

Quando aprendemos a fazer algo, realizamos nossas ações num ato espontâneo, porém algo pode sair diferente do esperado ou não estar de acordo com nossas expectativas, o que nos leva a dois caminhos: ignorar o fato, na tentativa de "preservar a constância de nossos padrões normais de conhecer-na-ação" ou podemos agir através da reflexão. Através da reflexão podemos agir de duas formas: "reflexão na ação" e "reflexão sobre a ação" (Schön, 2000, p. 32).

Surge então, o segundo elemento: a "reflexão na ação". Trata-se da reflexão no decurso da própria ação, sem interrompê-la, porém com breves momentos de distanciamento e a reformulação da ação enquanto ainda está sendo realizada (Alarcão, 1996, p. 16). 
O terceiro elemento é a "reflexão sobre a ação", que para Schön é quando "pensamos retrospectivamente sobre o que fizemos, de modo a descobrir como nosso ato de conhecer-na-ação pode ter contribuído para um resultado inesperado" (Schön, 2000, p. 32).

Caracteriza-se pela reconstrução mental da ação pra tentar analisála retrospectivamente. Este tipo de reflexão acontece quando a ação assume uma forma inesperada, ou quando, por qualquer motivo, a percebemos sob uma ótica diferente da habitual (Alarcão, 1996, p. 17).

Todo este repertório de experiências que se mobiliza em situações similares, configurando um conhecimento prático, pode não dar conta de novas situações, que apresentam problemas que superam o repertório criado, exigindo "uma busca, uma análise, uma contextualização, possíveis explicações, uma compreensão de suas origens, uma problematização, um diálogo com outras perspectivas, uma apropriação de teorias sobre o problema, uma investigação, enfim" (Pimenta, 2005, p. 20).

A esse movimento, Schön denomina o último elemento, a "reflexão sobre a reflexão na ação", que ultrapassa todos os momentos anteriores. Trata-se do "processo que leva o profissional a progredir no seu desenvolvimento e a construir a sua forma pessoal de conhecer". "Ajuda a determinar as nossas ações futuras, a compreender futuros problemas ou a descobrir novas soluções" (Alarcão, 1996, p. 17).

Para Pimenta (2005, p. 20) há em Schön "uma forte valorização da prática na formação dos profissionais; mas uma prática refletida, que Ihes possibilite responder às situações novas, nas situações de incerteza e indefinição". Mas para a autora é preciso deixar claro que o saber docente não se pauta somente na prática, sendo nutrido também pelas teorias da educação, que dotam os sujeitos de 
"variados pontos de vista para uma ação contextualizada, oferecendo perspectivas de análise para que os professores compreendam os contextos históricos, sociais, culturais, organizacionais e de si próprios como profissionais".

O trabalho docente precisa ser marcado por uma postura reflexiva, e assim essa capacidade precisa ser explorada no processo de formação do professor. Reflexão também significa o reconhecimento de que o processo de aprender a ensinar se prolonga por toda a carreira do professor (Zeichner, 1993, p. 17).

Ser professor reflexivo implica na consciência de uma capacidade de pensamento e reflexão que caracteriza o ser humano, não como mero reprodutor, mas como capaz de ser criativo em suas ações, agindo de forma inteligente e flexível, situada e reativa diante de situações muitas vezes incertas e imprevistas (Alarcão, 2010).

\section{Para Alarcão (1996, p. 18) o formando \\ precisa assumir uma postura de empenhamento autoformativo e autonomizante, tem de descobrir em si as potencialidades que detém, tem de conseguir ir buscar ao seu passado aquilo que já sabe e que já é e, sobre isso, construir o seu presente e o seu futuro, tem de ser capaz de interpretar o que vê fazer, de imitar sem copiar, de recriar, de transformar. Só o conseguirá se refletir sobre o que faz e sobre o que vê fazer.}

De acordo com Silva e Sá-Chaves (2008, p. 722) a escola, enquanto instituição formativa,

deve contribuir para a formação de profissionais cujo perfil de competência lhes permita intervir no seu contexto de trabalho de forma crítica, coletiva e integradora. Ou seja, deve contribuir para desenvolver nos futuros profissionais uma cultura de cidadania, tornando-os cada vez mais responsáveis, participativos e ativos na transformação dos contextos de trabalho e de vida. Para tanto, é fundamental estimular, no estudante em formação, o desenvolvimento da sua capacidade para compreender, global e sistemicamente, os problemas que a especificidade dos contextos e das respectivas circunstâncias Ihes colocam. 
Em, Educando o profissional reflexivo, Schön narra a interação entre o violoncelista Pablo Casales e uma estudante. Ele inicia ensinandoa a tocar exatamente como ele fazia, o que a leva a se tornar uma cópia fiel do mestre. Chegado neste ponto, o mestre pega no violoncelo e toca a mesma peça que the havia ensinado (uma peça de Bach), e o faz de maneira completamente nova. Ao terminar diz a estudante: "O que acabo de the demonstrar é uma improvisação de Bach. A partir de agora é assim que deve estudar sua obra: improvisando".

Para Alarcão (2010, p. 48) nessa passagem, Schön deixa claro os "limites do ato de ensinar em relação às potencialidades do ato de aprender". Daí emerge o poder da criatividade, caracterizando-se na capacidade que o ser humano tem de encontrar sua própria maneira de agir e intervir em sua vida social, a partir da sistematização de seus conhecimentos.

Pensar a formação exige entender que o diálogo assume um papel de enorme relevância, e deve acontecer em 3 dimensões: "o diálogo consigo próprio; um diálogo com os outros incluindo os que antes de nós construíram conhecimentos que são referência e o diálogo com a própria situação". Este diálogo não pode permanecer somente em nível descritivo, precisa atingir um "nível explicativo e crítico que permita aos profissionais do ensino agir e falar com o poder da razão" (Alarcão, 2010, p. 49).

Apesar da capacidade de reflexão ser inata ao ser humano, é comprovada a dificuldade que as pessoas, em qualquer idade, revelam ao por em prática os mecanismos reflexivos. Necessita-se de um esforço muito grande para passar do nível meramente descritivo ou narrativo para um nível onde se buscam "interpretações articuladas e justificadas e sistematizações cognitivas" (Alarcão, 2010, p. 49). A seguir, os diferentes níveis de reflexão, segundo alguns autores. 


\subsection{NÍVEIS DE LÓGICA REFLEXIVA}

Levando em consideração Liberalli (1999) e Zeichner e Liston (1987) encontram-se os três níveis de reflexão propostos por Van Manem (1977), classificação muito utilizada por vários autores:

1. Reflexividade técnica - preocupada com a eficiência e eficácia dos meios para atingir determinados fins e com a teoria como meio para previsão e controle dos eventos. Centra-se mais na descrição das ações que acontecem no contexto de sala de aula. Essas ações não são interpretadas, justificadas ou criticadas.

2. Reflexividade prática- visa ao exame aberto dos objetivos e suposições e o conhecimento que facilita o entendimento dos problemas da ação. Neste nível o profissional identifica problemas e pode, muitas vezes, fundamentar a sua ação à luz dos seus conhecimentos e valores.

3. Reflexividade crítica- relacionada às duas ênfases anteriores, porém valorizando critérios morais e as análises de ações pessoais em contextos histórico-sociais mais amplos. Este nível remete para um questionamento em relação à prática do profissional, pois além de identificar o problema, propõe possíveis soluções. Além dos conhecimentos científicos, leva em consideração aspectos relacionados à ética e a moral.

Similar a esta classificação, Sá-Chaves (2000, p. 22), referindo-se a utilização de portfólios reflexivos na formação de professores, propõe 3 níveis de lógica reflexiva: "nível técnico", "nível crítico" e "nível metacrítico". 
Sá-Chaves (2002) acrescenta mais dois níveis de reflexão aos anteriores, o prático e o metapráxico. O nível prático aparece como um desdobramento do nível técnico e o nível metapráxico se dará na prática do professor já em exercício. Para este estudo não foi considerada relevante a diferenciação entre os níveis técnico e prático, uma vez que a reflexão nestes níveis possui características basicamente descritivas. Assim, as narrativas foram categorizadas em apenas três níveis (técnico, crítico e metacrítico) propostos por Sá-Chaves (2000).

\subsubsection{Nível Técnico de Lógica Reflexiva}

Para Sá-Chaves (2000, p. 22) este nível caracteriza-se pela

Narração de episódios epistemicamente relevantes no sentido de que, para o formando, constituíram momentos e oportunidades fulcrais de (re)construção do seu saber pessoal.

Figura 2: Nível Técnico de Lógica Reflexiva

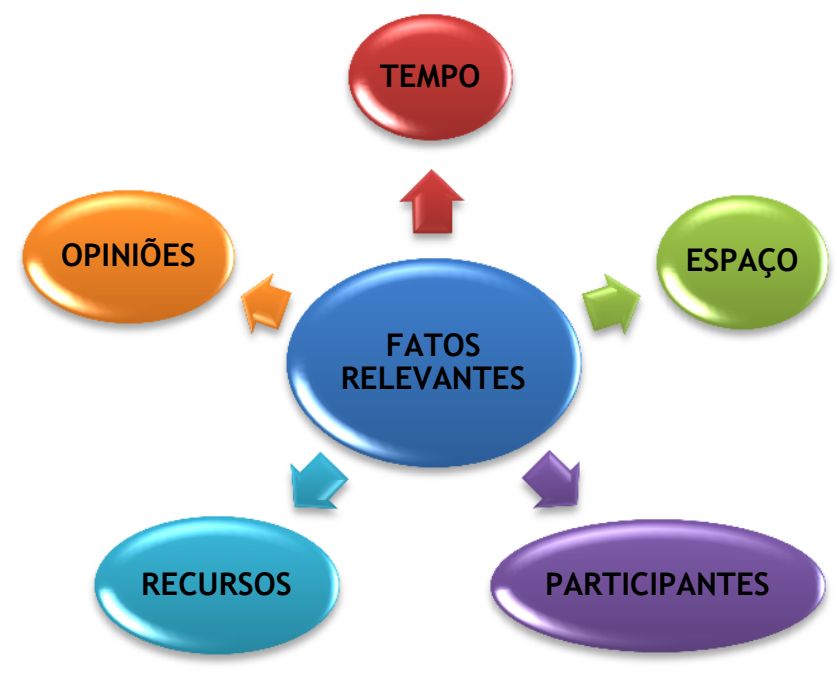

Fonte: Baseada em Sá-Chaves (2000) e Sadalla e Sá-Chaves (2008). Autor: Débora Rodrigues Vaz.

Baseando-se em Sadalla e Sá-Chaves (2008), apresentam-se a seguir algumas características das narrativas que podem ser 
encontradas no nível técnico de lógica reflexiva: o indivíduo descreve os fatos que ocorreram ponderando alguns elementos desta ocorrência como o tempo, o espaço, os participantes, os recursos, entre outros, e pode também emitir opiniões, dando um caráter mais pragmático à sua ação (Figura 2).

\subsubsection{Nível Crítico de Lógica Reflexiva}

Para Sá-Chaves (2000, p. 22) este nível caracteriza-se pela

Reflexão sobre os fatos narrados nos episódios, identificando as suas múltiplas e possíveis causas, consequências e significados, sobre o papel dos contextos na determinação dos fatos, sobre as funções e papéis desempenhados e sobre as concepções que os sustentam e ainda sobre novos papéis e novas funções que poderiam ser desempenhados à luz de novas concepções. Enfim, sobre a hipótese sempre nova da construção de outros futuros mais refletidos e mais aferidos no quadro da intercultura que a diversidade contextual garante.

Figura 3: Nível Crítico de Lógica Reflexiva

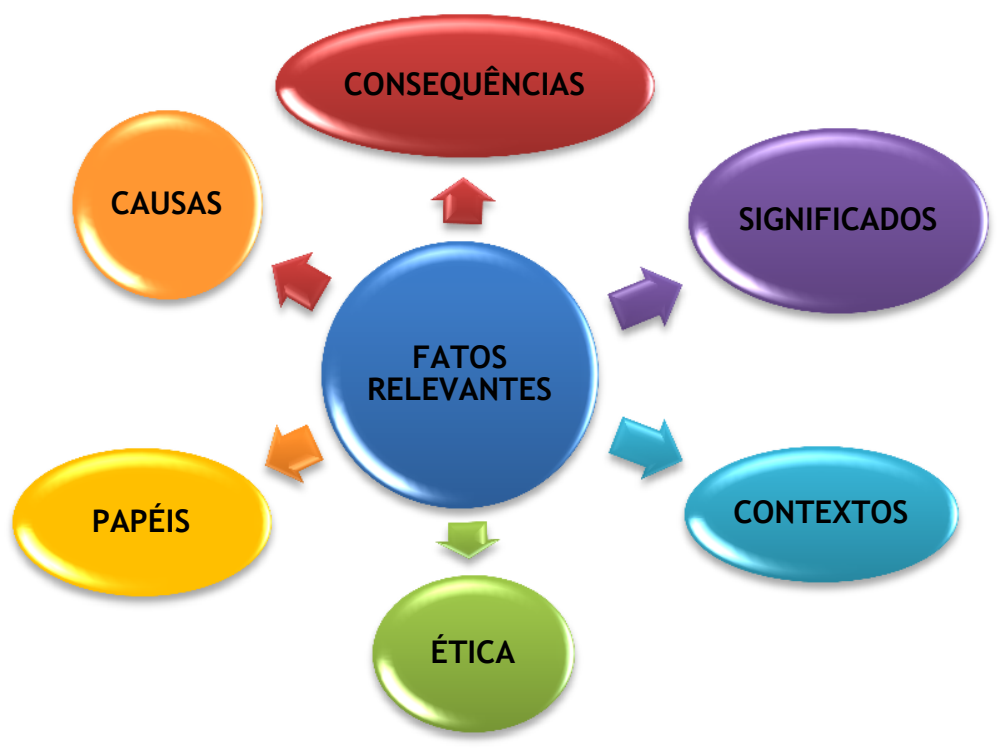

Fonte: Baseada em Sá-Chaves (2000) e Sadalla e Sá-Chaves (2008). Autor: Débora Rodrigues Vaz. 
Baseado em Sadalla e Sá-Chaves (2008), apresentam-se a seguir algumas características das narrativas que podem ser encontradas no nível crítico de lógica reflexiva: o indivíduo, ao analisar criticamente 0 acontecimento a partir de uma visão ética, aponta 0 que ocorreu e o que poderia ter acontecido em função de alguns valores como justiça, respeito, solidariedade, etc (Figura 3).

\subsubsection{Nível Metacrítico de Lógica Reflexiva}

Para Sá-Chaves (2000, p. 22) este nível caracteriza-se pela

Reflexão sobre si próprio, questionando os seus próprios papéis, funções, desempenhos e concepções, tornandose concomitantemente ator, sujeito reflexivo e objeto da própria reflexão. Trata-se do processo que visa conhecer-se para poder tornar-se, através do esforço próprio, da consciência clara e da coragem maior. E trata-se também de refletir matacognitivamente para, com o conhecimento emergente dessa reflexão, poder intervir praxicamente nos contextos e em si próprio estimulando a hipótese de devir.

Neste nível, o formando reflete não apenas "sobre os fatos que narra, mas sobretudo sobre o seu próprio papel no sucesso e/ou insucesso dos próprios fatos e assim repensar-se, repensando a sua própria prática" (Sá-Chaves, 2000, p. 33).

Este nível requer, por parte do docente, a capacidade para reconhecer-se como uma das variáveis do processo de ensino e aprendizagem, tornando-se assim, um dos fatores mais determinantes no sucesso/insucesso desse processo (Tomaz, 2007, p. 36). 
Figura 4: Nível Metacrítico de Lógica Reflexiva

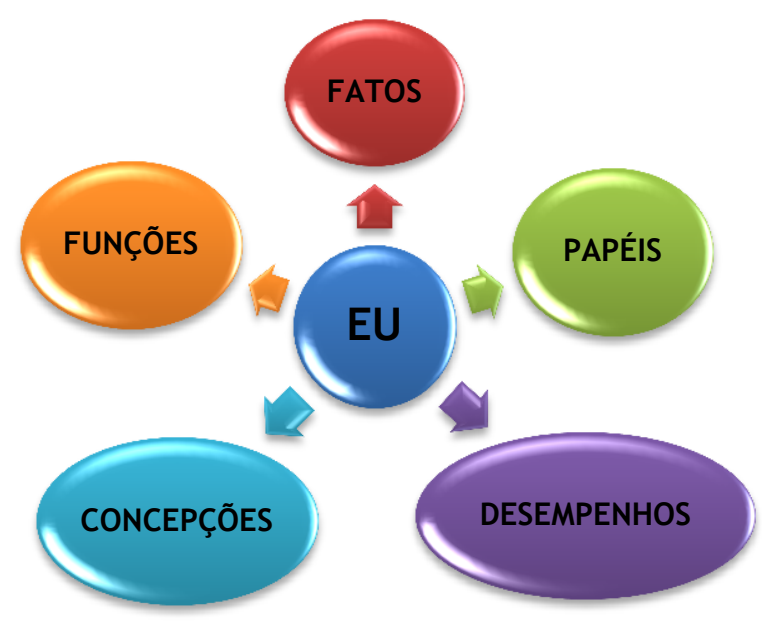

Fonte: Baseada em Sá-Chaves (2000) e Sadalla e Sá-Chaves (2008). Autor: Débora Rodrigues Vaz.

Baseado em Sadalla e Sá-Chaves (2008), apresenta-se a seguir algumas características das narrativas que podem ser encontradas no nível metacrítico de lógica reflexiva: o indivíduo, ao analisar a situação e a si mesmo, se reconhece como um dos responsáveis pelo acontecimento focalizado (Figura 4). 
4 O ESTÁGIO CURRICULAR SUPERVISIONADO E A FORMAÇÃO DOCENTE 


\section{O ESTÁGIO CURRICULAR PROFISSIONAL E A FORMAÇÃO DOCENTE}

Para adquirir as competências e habilidades específicas, os licenciandos de Enfermagem devem realizar atividades práticas em escolas de Enfermagem e instituições de saúde.

De acordo com a Resolução no 299/2005, o estágio em Enfermagem é considerado pela legislação educacional vigente como "atividade de aprendizagem social, profissional e cultural, proporcionada aos estudantes de ensino técnico e de graduação pela participação em situações reais de vida e de trabalho em seu meio, sendo realizada na comunidade geral ou a pessoas jurídicas de direito público ou privado, sob responsabilidade e coordenação de instituição de ensino (COFEN, 2005).

A legislação citada faz menção ao Estágio Clínico em Enfermagem, assim para a licenciatura recorre-se também à literatura sobre o estágio em pedagogia.

Para Freire (2001, p. 2) o estágio pedagógico possibilita uma primeira aproximação à prática profissional, promovendo a "aquisição de um saber, de um saber fazer e de um saber julgar as consequências das ações didáticas e pedagógicas desenvolvidas no quotidiano profissional". Assim, o estágio pedagógico ao permitir a interação com estudantes na sala de aula e com os supervisores, proporciona a aquisição de saberes profissionais e mudanças, quer nas estruturas conceituais, quer nas concepções de ensino.

Ainda segundo Freire (2001, p. 19), o estágio pedagógico constitui a "vertente prática" dos cursos de preparação de professores, permitindo a iniciação à prática letiva, através do envolvimento dos licenciandos em atividades letivas e em atividades de formação que possibilitem a reflexão, quer sobre as experiências vivenciadas e sua 
influência no pensar e agir profissional, quer sobre os efeitos de suas ações nos estudantes. Os estágios permitem a aquisição de saberes relacionados ao "como ensinar" e o "como agir" profissionalmente e também a conscientização das mudanças interiores que vão acontecendo, o que pode facilitar a transição do pensamento acadêmico para o pensamento pedagógico.

Dessa forma, os licenciandos precisam realizar atividades relacionadas à sua profissão, experimentá-las, ter oportunidade de refletir sobre o que deu certo e sobre o que não deu, para tentar aprimorar seu desempenho.

Para Silva (2011, p. 10), "a reflexão sobre a prática docente, por meio do Estágio supervisionado, é fundamental para que as problemáticas existentes no interior das escolas aflorem aos olhos dos estudantes, viabilizando uma análise da realidade à luz da teoria discutida em sala de aula". Isto possibilita ao estudante a construção de novas propostas de mudanças, o que de certa forma já o prepara para a futura profissão e em uma possível atuação transformadora.

Silva e Sá-Chaves (2008), fundamentadas em Schön (1983), referem que

as ações desenvolvidas pelos formandos devem ser sempre refletidas, pois é na reflexão sobre as práticas desenvolvidas, avaliadas e continuamente re-aferidas, que se reconstrói o conhecimento prévio, tornando emergente da própria prática uma nova compreensão dos fenômenos em análise, numa perspectiva integradora dos referenciais teóricos e da informação que apenas na prática reside.

No curso de Licenciatura o enfermeiro ou futuro enfermeiro acompanhará os estudantes (futuros auxiliares ou técnicos em enfermagem) na teoria e na prática, ou seja, realizará estágio em escolas (sala de aula e laboratório) e em instituições de saúde (hospitais, clínicas e Unidades Básicas de Saúde), sempre acompanhado de um professor, também enfermeiro. 
$\mathrm{Na}$ instituição de saúde, o estágio assemelha-se ao estágio clínico, pois o licenciando precisa acompanhar os estudantes na assistência ao cliente, o que envolve também o relacionamento com os funcionários da instituição e familiares. Enquanto estudante o licenciando deve ser acompanhado por um enfermeiro, que aqui será chamado de professor supervisor. Segundo a Resolução $n^{\circ}$ $371 / 2010$, o professor supervisor de estágio não pode acumular as funções docente, assistencial e/ou administrativa durante o desenvolvimento do estágio (COFEN, 2010)

Há escassa literatura abordando o estágio em cursos de licenciatura em Enfermagem, assim torna-se necessário trazer alguns aspectos referentes a estágios em outras áreas.

Para Simões, Alarcão e Costa (2008, p. 93) no estágio clínico,

o estudante ao encontrar-se inserido num ambiente vivo que atua sobre ele e sobre o qual ele reage, aprende a interiorizar os elementos sócio-culturais do meio, integrando-os na estrutura da sua personalidade por influência de experiências com agentes significativos e aprende a adaptar-se a este ambiente.

É desejável que os estágios proporcionem condições que permitam aos estagiários refletir sobre sua prática, ajudando-os na construção de um conhecimento pedagógico que o embasará ao longo de sua vida profissional. Assim como o estudante para se tornar reflexivo precisa de um docente reflexivo, o docente em sua formação também precisa de um supervisor reflexivo, que Alarcão $(1996$, p. 8) define como:

formador, que detentor das três atitudes básicas identificadas por John Dewey (abertura de espírito, responsabilidade e empenhamento), analisa, numa postura prospectiva, interativa e retrospectiva, as implicações da sua atuação não só ao nível técnico e prático, mas também crítico ou emancipatório, para ser o agente do desenvolvimento automizante do professor. É a pessoa que sabe adaptar, à sua autoformação, as estratégias de formação reflexiva que usa com os formandos. É o profissional que procura a resposta para problemas que se colocam na encruzilhada dos fatores que tornam compreensível o próprio problema. 
O papel do professor supervisor é imprescindível. Para Amaral, Moreira e Ribeiro (1996, p. 91), o supervisor/orientador de estágio deve ser visto como "o promotor de estratégias que irão desenvolver nos futuros professores o desejo de refletirem e, através da reflexão, a vontade de se desenvolverem em continuum".

Para Alarcão (2001, p.108)

essa nova perspectiva de formação e das aprendizagens coloca na primeira linha das preocupações dos alunos e dos professores a questão dos métodos de trabalho. Aprender a trabalhar, a estudar, a investigar, a refletir de um modo diferente é o grande desafio epistemológico da sociedade emergente.

Segundo a autora "a reflexão, para ser eficaz, precisa ser sistemática nas suas interrogações e estruturante dos saberes dela resultante" e enumera uma série de estratégias para o desenvolvimento da capacidade de reflexão, entre elas as narrativas; as perguntas pedagógicas; a observação das aulas; a auto-observação; a supervisão colaborativa e a elaboração de portfólios reveladores do processo de desenvolvimento seguido (Alarcão, 2010, p. 50).

A seguir serão exploradas as narrativas e os portfólios reflexivos, estratégias utilizadas pelo curso de licenciatura que contextualiza o presente estudo. 
5 ESTRATÉGIAS PARA A FORMAÇÃO REFLEXIVA 


\section{ESTRATÉGIAS PARA A FORMAÇÃO REFLEXIVA}

\subsection{NARRATIVAS}

Para Alarcão (2010, p. 59) as narrativas, através do ato da escrita, revelam o modo como os seres humanos experienciam o mundo. As situações por nós vividas constituem-se normalmente como pontos de partida para a reflexão, que poderá acontecer em níveis variados. As narrativas se tornam mais ricas a partir do momento que mais elementos significativos são registrados, por isso a importância do registro além dos fatos, incluindo o contexto físico, social e emocional do momento.

Nas palavras de Frison e Simão (2011, p. 198) "a pessoa, ao narrar, narra-se e, ao fazê-lo, ressignifica experiências, vivências, aprendizagens, dando-Ihes novo significado".

É difícil adquirir o hábito de escrever narrativas, porém para Alarcão (2010, p. 58) se "adquirido na formação inicial, tem grandes probabilidades de perdurar pela vida profissional" e assim ajudará a "analisar a vida, desdobrará o percurso profissional, revelará filosofias e padrões de atuação, registrará aspectos conseguidos e aspectos a melhorar, constituirá um manancial de reflexão profissional a partilhar com os colegas".

Segundo a mesma autora, é preciso atentar-se para como e onde se dará o escrito deste relato, pois a pressa ou a falta de tranquilidade podem levar a simplificação de algo que é complexo, impedindo que a reflexão se faça durante o próprio ato de escrever, e evitando que ela se aprofunde mais tarde quando se relerem os registros.

Para Fortuna et al. (2012), os registros sistematizados auxiliam o estudante a organizar seu pensamento, sua vivência e suas buscas teóricas. 
O uso das narrativas pode contribuir para a formação de professores reflexivos, se o supervisor habituar os seus estagiários a registrarem as suas práticas, a refletirem sobre elas e até a partilharem esses registros. As narrativas produzidas durante a formação inicial e durante a vida profissional poderão constituir "documentos profissionais e pessoais preciosos, cuja análise posterior poderá contribuir para a avaliação e reconstrução permanentes dessas atuações (Amaral, Moreira, Ribeiro, 1996, p. 107).

Assim os autores definem o papel do supervisor:

1. Ajudar os estagiários a estruturar as narrativas partindo das perguntas mais simples para as mais complexas, tornando-os cada vez mais autônomos nessa redação;

2. Ajudar na análise das mesmas, de modo a que possam tirar conclusões sobre os diferentes padrões de atuação e encontrar os problemas que necessitem de remediação.

3. Criar um clima que permita que essas narrativas sejam partilhadas, habituando assim aquele grupo de estagiários a dividir, discutir e tentar gerir as angustias e os sucessos contidos nessas narrativas, que poderão ser formativos para todos os intervenientes.

As narrativas podem assumir um caráter autobiográfico, ou ir além, tendo como foco de atenção os estudantes, a escola, o comportamento da sociedade ou dos políticos perante a educação, isto é, tudo aquilo que permita compreender as finalidades e os contextos educativos. Esses registros permitirão tirar conclusões sobre a evolução e desenvolvimento do professor nas suas dimensões pessoal e profissional (Alarcão, 2010, p. 58).

\subsection{PORTFÓLIO REFLEXIVO}

Segundo Nunes e Moreira (2005, p. 53),

o termo portfólio deriva do verbo latino portare (transportar) e do substantivo foglio (folha) e tem vindo a designar a pasta que contém desenhos, fotos, textos, pautas de música, seja de profissionais diversos ou de alunos. Emprestado do portfólio do artista, o conceito 
tem vindo a ser aprofundado e adoptado no ensino elementar, secundário e superior.

O conceito de portfólio é proveniente da área das artes e sua concepção original "encerra a idéia de apresentação do artista através das suas obras mais características a fim de que outros possam apreciar e avaliar o seu valor a partir do que ele próprio considera mais significativo" (Alarcão, 2010, p.60).

O seu uso na educação começou a difundir-se na década de 90, principalmente nos Estados Unidos, sendo utilizado em diversas áreas do conhecimento, como a matemática, engenharia, arquitetura, etc.

Gardner (1995, p. 129) ampliou e ressignificou o conceito de portfólio e chamou-o de processofólio, pois nele "o aluno inclui não apenas os trabalhos concluídos, mas também os esboços originais, desenhos provisórios, críticas dele mesmo e de outros, trabalhos artísticos de outros que ele admira ou desgosta e que têm algo a ver com seu atual projeto".

Muitos autores acreditam que o termo portfólio limita a amplitude e dimensão de seu uso e propõem o termo "processofólio. Para Wolf (1991 apud Gardner, 1995, p. 191):

\begin{abstract}
Num portfólio padrão, o indivíduo reúne seus melhores trabalhos para algum tipo de competição ou exibição. Em contraste, num processofólio o aluno deliberadamente tenta documentar - para ele mesmo e para os outros - 0 pedregoso caminho de seu envolvimento num projeto: os planos iniciais, os rascunhos provisórios, os falsos pontos de partida, os pontos críticos, os objetos de domínio que são relevantes e os que ele gosta ou desgosta, várias formas de avaliações provisórias e finais, e os planos para projetos novos e subseqüentes.
\end{abstract}

Outros termos também são encontrados, como porta-fólio e hoje com as tecnologias e o uso da internet são encontrados também webfólio, e-portafólio e e-fólio. 
Para ser bem utilizado é necessário que o portfólio seja bem compreendido pelos professores e estudantes, que seja construído de forma a constituir um verdadeiro documento, um histórico capaz de tornar claro o percurso do desenvolvimento e do conhecimento adquirido pelo estudante.

Este instrumento pode assumir várias formas em relação a sua construção e seu conteúdo, sendo que "a seleção dos elementos a incluir num portfólio pode ser da responsabilidade do aluno, do professor, da escola ou mesmo de uma combinação destes intervenientes" (Sá-Chaves, 2005, p. 54).

O portfólio pode ser acondicionado em diversos tipos de continentes, ou seja, diferentes locais, que poderão ter diversas formas como, por exemplo: uma pasta, caixa, cd-rom, DVD ou até mesmo permanecer disponível da web, como uma homepage, o que pode dar-lhe nomenclaturas diferentes.

Love, Mckean e Gathercoal (2004) diferenciaram os conceitos portfólio, e-portfólio e webfólio, sendo portfólio, uma coleção de materiais em papel arquivados em um dossiê, e-portfólio, uma coleção de documentos multimídia arquivados em CD-ROM ou outro meio eletrônico, porém não disponíveis na Web e o Webfólio, uma coleção totalmente integrada de documentos multimídia, disponíveis na Web, podendo incluir dados curriculares, produções e trabalhos dos estudantes, feedbacks e avaliações dos professores. É preciso deixar claro que estas nomenclaturas variam muito entre autores.

Para Santos (2006, p. 318)

do ponto de vista da mídia, o portfólio pode ser construído a partir de um suporte físico a exemplo das pastas-arquivos, classificadores, cadernos, CD-ROM, etc, ou a partir do suporte digital, a exemplo dos webfólios, páginas ou sites publicados na Internet, ou de interfaces em ambientes virtuais de aprendizagem (AVA), utilizados na prática pedagógica na educação online. 
Outro fator importante a ser considerado é a participação do estudante na definição dos critérios para a construção do portfólio, tendo em vista que não existe uma regra ou uma formatação, que sua construção deve ser flexível, adaptável assim como a construção do conhecimento: uma construção histórico-social. Esta construção não deve ser influenciada somente pelo universo acadêmico, deve ir muito além da sala de aula.

Para Villas Boas (2008, p. 48),

o portfólio pode ser construído durante um mês, um bimestre, um semestre, um curso, uma disciplina ou o tempo do qual se dispuser e de acordo com os objetivos do trabalho a ser realizado. Pode abranger um tema, uma unidade ou as atividades desenvolvidas durante um determinado período. Em qualquer situação, sejam os alunos crianças ou adultos, a preparação para o uso do portfólio é necessária.

Para Hoffmann (2006, p. 133) o portfólio deve "constituir-se em um conjunto de dados que expresse avanços, mudanças conceituais, novos jeitos de pensar e de fazer, alusivos à progressão do estudante".

O portfólio possibilita o acompanhamento do processo no qual o estudante está inserido enquanto constrói seu conhecimento, e assim sua utilização pode estar intimamente ligada ao desenvolvimento de projetos ou solução de problemas, o que faz o aprendizado mais significativo e motivador.

Este instrumento também individualiza o ensino, uma vez que analisando o seu conteúdo, o docente pode traçar o perfil do estudante, evidenciando seus interesses, suas habilidades e capacidades desenvolvidas e as que ainda estão por desenvolver, o que servirá como base para o planejamento de atividades a serem desenvolvidas especialmente para este estudante. 
Para Santos (2005, p. 55) "cada professor deverá sinalizar com clareza, o conteúdo e as leituras necessárias dentro da sua disciplina e enumerá-las para que não haja dúvida no momento da elaboração do portfólio. Ele deve exercer o seu papel de mediador no processo de aprendizagem." Porém o autor afirma que apesar das orientações serem as mesmas para todos, cada estudante dará o seu toque pessoal, não só em relação à apresentação, mas também ao acréscimo de informações extras que contemplem o progresso individual.

Segundo Villas Boas (2008, p. 41),

cabe destacar que o uso do portfólio beneficia qualquer tipo de aluno: o desinibido, o tímido, o mais e o menos esforçado, o que gosta de trabalhar em grupo e o que não gosta, o mais e o menos motivado ou interessado pelo trabalho escolar, o que gosta de escrever e até o que não gosta - porque ele pode passar a gostar, assim como pode apresentar suas produções usando outras linguagens. [...] permite ao aluno acompanhar o desenvolvimento de seu trabalho, de modo a conhecer suas potencialidades e os aspectos que precisam ser melhorados.

É importante ressaltar a dimensão reflexiva do portfólio, pois como afirma Sá-Chaves (2000, p.15),

os portfolios são vistos e utilizados como instrumentos de estimulação e como factores de activação do pensamento reflexivo, providenciando oportunidades para documentar, registrar e estruturar os procedimentos e a própria aprendizagem, ao mesmo tempo que, evidenciando para o próprio formando e para o formador, os processos de autorreflexão, permitem que este último aja em tempo útil para o formando, indicando novas pistas, abrindo novas hipóteses que facilitem as estratégias de autodirecionamento e de reorientação, em síntese, de autodesenvolvimento.

Para auxiliar o processo, o professor deve conduzir o estudante ao desenvolvimento de diversos níveis de reflexão, para que reflita sobre o porquê da escolha de determinado documento; compare trabalhos, justificando sua escolha no enriquecimento do seu portfólio e como seu portfólio revela seu progresso. 
De acordo com Dias (2005, p. 114) o processo narrativo, no exercício do portfólio reflexivo, leva o sujeito por um sentimento de autoria, proporcionando autoconhecimento, na medida em que o formando faz uma reconstituição de significados das experiências consideradas mais importantes da sua vida.

O portfólio, enquanto "texto autobiográfico é, pelas características da sua produção e do seu conteúdo, um texto idiossincrático, ou melhor, pessoal, tanto na seleção de acontecimentos como no modo de expressão". (Ramos, Gonçalves, 2005, p. 137).

Segundo Gardner (1995, p. 102) a reflexão deve estar presente no processo avaliativo, proporcionando ao estudante monitoração do próprio processo de aprendizagem, como uma atividade metacognitiva e afirma que:

Um dos aspectos mais importantes do crescimento intelectual, infelizmente bastante negligenciado, é a capacidade de distanciar-se do próprio trabalho, de monitorar os próprios objetivos, de avaliar o progresso que está sendo feito, de avaliar como o curso pode ser corrigido, de que maneira fazer uso do conhecimento obtido em sala de aula e com os outros, e assim por diante.

Segundo Carvalho e Porto (2005, p. 20)

... o portfólio educacional pode servir para demonstrar as competências desenvolvidas durante o curso para a busca de um emprego. Entretanto, seu propósito é antes de tudo educacional: de formação e avaliação autorreflexiva ao longo de toda a vida profissional, ajudando a orientar e a dar forma à educação continuada. O portfólio educacional, como mediador na formação, valoriza, sobretudo, o desenvolvimento da autonomia no direcionamento da formação profissional.

Os mesmos autores afirmam que

a responsabilidade pela formação contínua está na dependência do investimento pessoal de cada um. [..] cada pessoa deve engajar-se na sua formação e avaliação autorreflexiva, principalmente no seu crescimento pessoal e profissional.[...] Com o tempo, a reflexão afeta as escolhas e as direções de modo significativo. O processo de autoformação pressupõe a prática do registro e da reflexão numa base continuada. 
Para Coelho e Campos (2003, p. 15) o portfólio, enquanto instrumento, permite ao estudante consultas posteriores, como um instrumento-memória, e também a possibilidade de aprender depois da escola.

Segundo Alves e Anastasiou (2006, p. 104) "o que é importante não é o portfólio em si, mas o que o estudante aprendeu ao criá-lo ou, dito de outro modo é um meio para atingir um fim e não um fim em si mesmo".

Os dados registrados no portfólio subsidiam professor e estudante em seus processos de trabalho, nas tarefas de autorreflexão que antecedem a autoavaliação.

Acredita-se que o uso de instrumentos como o portfólio no processo de ensino-aprendizagem, vai ao encontro do pensamento pedagógico atual, pois promove ao estudante a oportunidade de refletir, diagnosticando suas dificuldades, autoavaliando o seu desempenho e autorregulando a sua aprendizagem.

$\mathrm{Na}$ Enfermagem sua utilização também pretende alcançar os mesmos propósitos. Os autores a seguir falam sobre o uso do portfólio na graduação em Enfermagem.

Para Silva e Tanji (2008, p. 9) a

"confecção do portfólio reflexivo tem um potencial significativo ao ser considerado como um instrumento de aprendizagem e de acompanhamento do desempenho do estudante de Enfermagem."

Segundo os mesmos autores sua aplicabilidade e utilidade se fortalecem quando são evidenciadas algumas vantagens como a autocrítica, a liberdade para o desenvolvimento da capacidade de reflexão, a ampliação das bases conceituais, a re-significação da aprendizagem, a avaliação contínua, entre outro benefícios. 
Para Pereira (2008, p. 165) os estudantes compreendem a finalidade do portfólio "como um instrumento que permite espelhar as suas reflexões e aprendizagens e reconhecem que o registro das experiências vividas permite recordá-las e compará-las".

Dentre as competências necessárias a formação do enfermeiro está o desenvolvimento da comunicação, muito utilizada em todos os aspectos do cuidado, incluindo o registro de suas ações. Tais competências também são necessárias à formação docente em Enfermagem. Assim, Freitas, Cunha e Batista (2008, p. 4692) citam como um aspecto importante a ser considerado:

A possibilidade do desenvolvimento da competência de comunicação escrita, através da seleção, organização e síntese que, pouco exercitadas na graduação dos profissionais de saúde têm lugar privilegiado na disciplina coma construção do Portfólio.

Muitas são as potencialidades descritas em relação ao uso do portfólio, porém sabe-se que há também muitas dificuldades em sua utilização.

Segundo Pereira (2008, p. 165) essas dificuldades podem causar um elevado nível de stress, que pode ser relacionado a alguns fatores como o pouco tempo para a sua elaboração e o aparecimento de dúvidas sobre como fazê-lo. Muitos estudantes referem ser um "trabalho muito individual, sem regras e onde é possível incluir tudo que se fez e vivenciou".

Por isso a necessidade de se ter objetivos claros, de esclarecer tais objetivos aos estudantes e proporcionar guias que colaborem na sua elaboração.

Rotas de Aprendizagem podem ser úteis para nortear sua elaboração. Para Schneider, Medeiros e Urbanetz (2009, p. 5) a Rota de Aprendizagem "deve servir como uma ponte, ligando o que o professor deseja e precisa ensinar com aquilo que o aluno precisa 
aprender", explicitando o caminho pretendido pelo processo ensino aprendizagem. Esta estratégia supera o processo de transmissão de informações e proporciona um direcionamento ao estudante, uma linha por onde ele deve se guiar em relação ao seu autoaprendizado.

Shores \& Grace (2001, p. 88) propõem para um melhor desenvolvimento do portfólio uma "política de portfólio", que se constitui segundo as autoras em "um pequeno conjunto de regras básicas para a coleta de itens a serem guardados", podendo expressar também como se dará a avaliação deste material. Afirmam também que "a definição de regras para o uso do portfólio deve começar por examinar a missão ou os objetivos de sua escola ou de seu programa de ensino", somados aos objetivos profissionais e aos objetivos de sala de aula.

Como existe uma preocupação com a formação reflexiva do estudante, as atividades solicitadas devem ter um caráter reflexivo e presumivelmente motivador, sendo capazes de estimular o estudante ao autoconhecimento. 
6 O PORTFÓLIO NA ESCOLA DE

ENFERMAGEM DA USP 


\section{O PORTFÓLIO NA ESCOLA DE ENFERMAGEM DA USP}

Para Püschel (2011, p. 25), as mudanças que vêm ocorrendo nos cursos de graduação pelo país, também tem sido mobilizadas pelo movimento iniciado em algumas universidades visando "a formação de um profissional crítico, reflexivo e com competências para se debruçar sobre os complexos problemas da realidade na busca de respostas, de soluções para transformar as realidades."

A Escola de Enfermagem da USP - São Paulo iniciou, em 2002, o processo de avaliação de seu currículo vigente até então visando a reorientação curricular, o que se intensificou a partir de 2004 com a criação do Grupo de Apoio Pedagógico (GAPEEUSP) que tem, entre outros objetivos, o papel de "contribuir para a elaboração de um projeto político-pedagógico capaz de propiciar a formação permanente de toda comunidade acadêmica dessa Escola" (Oliveira, Veríssimo, Püschel, Riesco, 2007, p. 822).

O novo Projeto Político Pedagógico (PPP) entrou em vigor em 2010 e apresenta uma proposta curricular organizada predominantemente em Módulos, que explicitam as articulações dos diferentes saberes, constituído por conjuntos de disciplinas ou disciplinas individuais (Püschel, Sigaud, Oliveira, Veríssimo, Riesco, 2009).

O novo currículo tem a finalidade de formar o(a) enfermeiro(a) generalista. Com carga horária total de 4.160 horas, duração de quatro anos, em período integral, tem como Eixo Central o Cuidado de Enfermagem, em seus diferentes sentidos, significados e dimensões (Püschel, 2011).

O bacharelado em Enfermagem da EEUSP tem como objetivo geral qualificar enfermeiros(as) frente aos princípios, diretrizes e práticas do Sistema Único de Saúde (SUS), tendo como pauta a 
compreensão das relações de trabalho em saúde e na sociedade, visando ao aprimoramento da dinâmica de gestão, a qualificação dos processos de cuidar e a proposição de projetos de intervenção, fundados no reconhecimento de diferentes demandas e sustentados por evidências científicas (Püschel, Sigaud, Oliveira, Veríssimo, Riesco, 2009).

A avaliação do processo ensino aprendizagem, parte importante do PPP, é vista como um acompanhamento processual, de caráter formativo, uma vez que deverá abarcar a análise dos avanços efetivados no processo de ensino-aprendizagem do estudante, do professor e dos conteúdos (Püschel, Sigaud, Oliveira, Veríssimo, Riesco, 2009).

Esta reorientação curricular contempla também o novo PPP do Curso de Licenciatura em Enfermagem, implementado também em 2010 e está em consonância com a proposta de formação de professores da LDB, seguindo também as diretrizes do Programa de Formação de Professores da USP. Tal Programa, amplamente discutido no âmbito da Universidade, foi aprovado pelo Conselho Universitário em 25/04/2004 e está sendo desenvolvido nas Unidades da USP, com o apoio da Comissão Interunidades de Licenciatura (CIL), ligada à Pró-Reitoria de Graduação (Sigaud, Oliveira, Veríssimo, Riesco, Püschel , 2011).

Trata-se de uma mudança curricular gerada pelas modificações estruturais do Bacharelado em Enfermagem, tendo em vista que os dois Cursos têm ingresso único no vestibular da Universidade de São Paulo (USP) e percursos formativos integrados (Sigaud, Oliveira, Veríssimo, Riesco, Püschel , 2011).

A Licenciatura em Enfermagem foi criada em 1974, vinculada à Faculdade de Educação e passou a ser responsabilidade da EEUSP em 2005. Seu objetivo é formar professores para atuar no ensino 
médio e profissionalizante em Enfermagem, "como sujeitos de transformação, comprometidos com a busca de respostas a desafios e problemas existentes no âmbito do ensino profissional em Enfermagem" (Sigaud, Oliveira, Veríssimo, Riesco, Püschel , 2011).

A matriz curricular do Curso de Licenciatura em Enfermagem da EEUSP articula-se ao Bacharelado, seguindo as Diretrizes Curriculares Nacionais dos Cursos de Graduação em Enfermagem (Parecer CNE/CES n.1135/2001). A Faculdade de Educação da USP participa ministrando as disciplinas de Didática e de Política e Organização da Educação Básica assegurando a integração tanto com o Bacharelado em Enfermagem da EEUSP, quanto com a Proposta de Formação de Professores da USP (Sigaud, Oliveira, Veríssimo, Riesco, Püschel , 2011).

Com este projeto, a Escola de Enfermagem da USP reafirma seu compromisso com a formação de professores para o ensino médio regular e o ensino profissionalizante em Enfermagem, buscando ampliar e aprofundar seu campo de conhecimentos pedagógicos e também os conhecimentos específicos na formação inicial. Investe na valorização do Curso de Licenciatura e apresenta uma nova proposta de integralização de conteúdos com o Bacharelado em Enfermagem que privilegia a formação e a produção de conhecimentos na área do ensino e também o contato mais imediato com as questões educacionais presente na realidade (Sigaud, Oliveira, Veríssimo, Riesco, Püschel , 2011).

A nova matriz curricular resulta do esforço coletivo da comunidade acadêmica da EEUSP e deve ser vista como um investimento na direção da renovação e do aperfeiçoamento da formação do professor do ensino médio e profissionalizante em Enfermagem (Sigaud, Oliveira, Veríssimo, Riesco, Püschel , 2011). 
Para o Projeto Político Pedagógico da Licenciatura em Enfermagem da USP:

\begin{abstract}
A construção do conhecimento em nível profissionalizante é pautada nas esferas técnicacientífica, ética, política e social, propiciando ao graduando espaço para pensar, sentir e formar novos conceitos e valores relacionados a sua futura prática profissional, ao assumir responsabilidades direcionadas ao processo de ensinar o cuidado de Enfermagem (Sigaud, Oliveira, Veríssimo, Riesco, Püschel , 2011).
\end{abstract}

A articulação entre os Cursos de Bacharelado e Licenciatura em Enfermagem tem o intuito de "contribuir para a melhoria da qualidade da assistência de Enfermagem, formando profissionais com capacidades para desenvolver habilidades e exercer plenamente o exercício da docência em cursos de formação profissional de nível técnico" (Sigaud, Oliveira, Veríssimo, Riesco, Püschel , 2011).

O novo currículo permite ao licenciando a oportunidade de participar de atividades em laboratórios de ensino e de acompanhar reuniões e supervisão de estágios em escolas profissionalizantes, desenvolvendo atividades didáticas, juntamente com os professores dessas escolas. Busca-se construir espaços de diálogo para trabalhar conflitos existentes na esfera da educação, nas dimensões social e política, compartilhando e entrelaçando os vários aspectos do ensino, com o intuito de ampliar sua visão sobre a educação, sob um prisma interdisciplinar e numa abordagem mais realista e compreensiva (Sigaud, Oliveira, Veríssimo, Riesco, Püschel , 2011).

As disciplinas Metodologia do ensino de enfermagem I e II, oferecidas no Bloco "Fundamentos Metodológicos do Ensino", tem como foco as bases teórico-metodológicas e práticas para a formação do professor. Estas estão vinculadas ao Estágio Curricular Supervisionado, assegurando a integração entre teoria e prática (Sigaud, Oliveira, Veríssimo, Riesco, Püschel , 2011). 
São objetivos destas disciplinas:

instrumentalizar o licenciando de enfermagem quanto aos aspectos teórico-metodológicos do processo ensino aprendizagem para atuar no ensino médio e no ensino profissionalizante de enfermagem e desenvolver e avaliar as ações educativas relacionadas com as práticas de enfermagem e de saúde (Sigaud, Oliveira, Veríssimo, Riesco, Püschel , 2011).

O Estágio Curricular Supervisionado é uma atividade obrigatória para o curso de Licenciatura. O Licenciando em Enfermagem da EEUSP terá espaço exclusivo para desenvolver atividades de ensino nas escolas de forma contínua, o que the proporciona condições para aprofundar seus conhecimentos teóricos e práticos, com maior integração e participação no planejamento, execução e avaliação do processo ensino aprendizagem vigente nas escolas (Sigaud, Oliveira, Veríssimo, Riesco, Püschel , 2011).

São objetivos do Estágio:

instrumentalizar o licenciando de enfermagem para ser professor no ensino médio e profissionalizante em enfermagem e capacitar para o exercício da formação profissional como professor visando a qualidade de ações educacionais, a partir da pluralidade dos caminhos do ensino em enfermagem e saúde (Sigaud, Oliveira, Veríssimo, Riesco, Püschel , 2011).

Os critérios utilizados para a seleção dos conteúdos e estratégias pedagógicas abordados nas disciplinas Metodologia do ensino de enfermagem I e II, levam em consideração sua relevância para a futura prática do docente em Enfermagem.

O curso se desenvolve principalmente por meio de atividades presenciais, porém a utilização de estratégias de comunicação virtual acontece em caráter complementar e tem como alguns de seus objetivos, estimular a utilização de tecnologias na educação em Enfermagem e promover uma aprendizagem colaborativa utilizando recursos do Ensino a Distância.

Prado, Martins e Alavarce (2011, p. 109) destacam

a necessidade da incorporação de diferentes mídias no processo de construção e reconstrução dos saberes na 
Enfermagem, visto que estas proporcionam o aprendizado a partir das múltiplas potencialidades, capacidades e interesses dos educandos, além de contribuir significativamente para um aprendizado coletivo e, por fim, para a viabilidade de sua construção. geral

As mesmas autoras acreditam na importância de estimular docentes e estudantes para o uso das novas tecnologias educacionais, trazendo novas perspectivas para os cursos de graduação, Licenciatura, pós-graduação e educação permanente por meio da construção e da utilização de hipermídias em ambientes virtuais de aprendizagem, adotando propostas pedagógicas inovadoras permitindo a aprendizagem significativa.

Para as aulas virtuais o curso utiliza a plataforma Moodle (Modular Object-Oriented Dynamic Learning Environment), um software livre, de apoio à aprendizagem e executado num ambiente virtual.

Entre os conteúdos abordados, utilizando Educação a Distância (EaD), encontram-se a aula virtual sobre "Portfólio" (Figura 5), desenvolvida na Disciplina Metodologia do ensino de enfermagem II - 2011, e disponibilizada na plataforma Moodle-USP (moodle.redealuno.usp.br). Esta aula teve como objetivo apresentar este instrumento e sua utilização na educação em enfermagem de forma prática, bem como aproximar os estudante de estratégias e ferramentas que facilitam a sua utilização visando o desenvolvimento da reflexão e o trabalho colaborativo, como o blog e a wiki (Vaz et al. 2011). 
Figura 5: Aula - Portfólio Educacional - Moodle

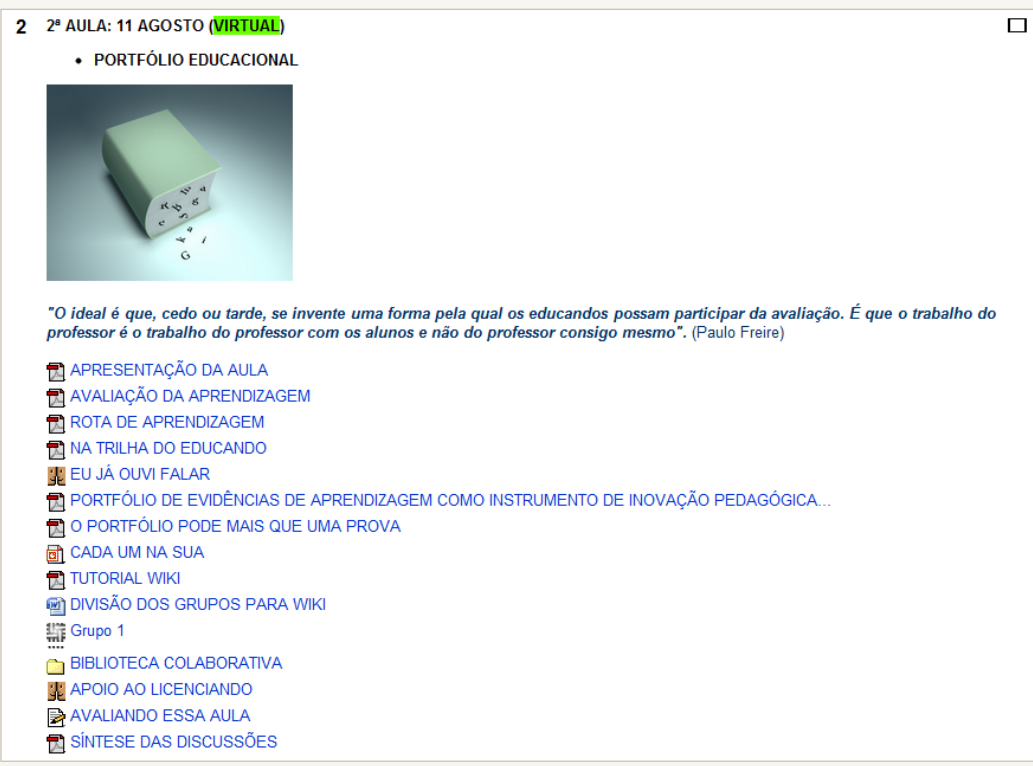

Autores: Débora R. Vaz; Denise Maria de Almeida; Cláudia Prado

Além da aula de portfólio, no ambiente virtual também foram desenvolvidas outras aulas, sobre temas importantes para a prática docente, como "Estratégias de ensino", "Metodologia dialética", "Andragogia e seus princípios" e "Teoria da aprendizagem significativa".

Como a avaliação do curso de Licenciatura prevê o acompanhamento do desempenho dos licenciandos, identificando competências e habilidades desenvolvidas ao longo do curso, bem como as facilidades e as dificuldades por eles apresentadas no processo de construção do conhecimento, decidiu-se por utilizar o portfólio como instrumento de acompanhamento da aprendizagem e avaliação do estágio curricular supervisionado.

Assim o portfólio, dentro do curso, foi elaborado individualmente e relacionado ao Estágio Curricular Supervisionado - integrado à disciplina ENO 436 - Metodologia de ensino de Enfermagem II - que aconteceu em diversas instituições de ensino técnico em Enfermagem e de saúde. Para auxiliar o licenciando na elaboração 
de seu portfólio foi disponibilizado no ambiente virtual uma "Rota de Aprendizagem" constituída por oito atividades (Apêndice A).

A Rota de Aprendizagem foi utilizada com a finalidade de nortear a confecção do portfólio, propondo etapas e atividades a serem realizadas durante o Estágio Curricular Supervisionado e auxiliando o desenvolvimento do processo de reflexão e a autoavaliação do estudante. 
7 PROCEDIMENTO METODOLÓGICO 


\section{PROCEDIMENTO METODOLÓGICO}

\subsection{TIPO DE PESQUISA}

Trata-se de Estudo documental exploratório-descritivo.

Para Reis (2010, p. 62) o estudo documental "objetiva investigar e explicar um problema a partir de fatos históricos relatados em documentos" que não foram analisados cientificamente, mas que são fontes valiosas de informações e dados antigos. Tais informações são encontradas em documentos pessoais como cartas, diários, fotos, vídeos, ofícios, informativos, etc e em documentos institucionais como relatórios de pesquisa que incluem dados estatísticos, gráficos, tabelas, boletins, periódicos, jornais, etc.

Segundo Zuin e Zuin (2010, p. 67), a importância deste tipo de análise encontra-se no fato destes documentos constituírem uma importante fonte estável dos fatos historicamente construídos, uma vez que podem ser consultados ao longo do tempo, "sendo os documentos uma fonte da construção e reconstrução da história, eles fazem parte de um determinado contexto e por isso permitem ao pesquisador obter informações a respeito deste".

Para Sá-silva, Almeida e Guindani (2009, p. 5) a pesquisa documental "é um procedimento que se utiliza de métodos e técnicas para a apreensão, compreensão e análise de documentos dos mais variados tipos".

Os documentos podem ser: de acesso fechado, acesso restrito (acessíveis apenas a determinados grupos profissionais), acesso a arquivo aberto (pode ser acessado por qualquer pessoa) e acesso de publicação aberta (documentos estão publicados e acessíveis a qualquer parte interessada) (Flick, 2009, p. 232). 
Esse tipo de estudo procura documentos de fonte primária, que podem ser encontrados em arquivos, fontes estatísticas e fontes não-escritas. Os arquivos podem ser públicos ou particulares. Os arquivos particulares pertencem a instituições de ordem privada, como bancos, igrejas, sindicatos, escolas e etc (Rampazzo, 2005, p. $51)$.

De acordo com Sá-silva, Almeida e Guindani (2009, p. 4)

Quando um pesquisador utiliza documentos objetivando extrair dele informações, ele o faz investigando, examinando, usando técnicas apropriadas para seu manuseio e análise; segue etapas e procedimentos; organiza informações a serem categorizadas e posteriormente analisadas; por fim, elabora sínteses, ou seja, na realidade, as ações dos investigadores - cujos e objetos são documentos - estão impregnadas de aspectos metodológicos, técnicos e analíticos.

A pesquisa descritiva tem como objetivo

descrever um objeto de estudo determinado, e estabelecer a inter-relação entre fenômenos e a população (grupo social), usando variáveis, como forma de procurar descobrir a freqüência com que os fatos acontecem no contexto pesquisado (Reis, 2010, p. 65) .

Para Andrade (2001 apud Reis, 2010, p. 65) na pesquisa descritiva se observa, registra, analisa, classifica e interpreta os fatos sem a manipulação ou interferência do pesquisador.

Segundo Santos e Candeloro (2006, p. 73) "as pesquisas de delineamento descritivo-exploratório tem objetivo fundamental de proporcionar ampla visão sobre o tema selecionado" e dedica-se ao levantamento bibliográfico e/ou documental.

Consiste em recolher e registrar os fatos da realidade sem que 0 pesquisador utilize meios técnicos especiais ou precise fazer perguntas diretas, não necessitando da utilização de um instrumento para a coleta de dados, como questionários ou entrevistas (Rampazzo, 2005; Santos, Candeloro, 2006). 


\subsection{CENÁRIO DO ESTUDO}

O estudo foi desenvolvido na Escola de Enfermagem da Universidade de São Paulo (EEUSP), no Curso de Licenciatura em Enfermagem.

\subsection{OBJETO DO ESTUDO}

Foram analisados os portfólios dos estudantes do curso de Licenciatura em Enfermagem da EEUSP, que concluíram a Disciplina Metodologia do Ensino de Enfermagem II e realizaram o Estágio Curricular Supervisionado em 2011.

\subsection{PROCEDIMENTO DE COLETA DE DADOS}

A coleta de dados iniciou-se após a aprovação do projeto de pesquisa pelo Comitê de Ética.

Os portfólios foram acessados na Plataforma Moodle através do endereço eletrônico http://moodle.redealuno.usp.br, que dá acesso a Escola de Enfermagem da USP (EEUSP) e a disciplina Metodologia do Ensino de Enfermagem II - 2011. Para o acesso foram disponibilizados login e senha.

Dentro do ambiente da disciplina foi possível acessar cada portfólio identificado pelo nome de cada estudante. Assim todos os documentos foram copiados para um arquivo e organizados, possibilitando a coleta e análise dos dados.

Foram analisados os seguintes itens relacionados ao estágio curricular supervisionado, propostos pelo portfólio em sua "Rota de Aprendizagem": Atividade 4 - "Descrição reflexiva da aula teórica 
ministrada" e Atividade 7 - "Descrição reflexiva da supervisão em campo de prática". Estas atividades foram selecionadas por apresentarem grande relação com a prática vivenciada pelo licenciando durante o estágio curricular supervisionado nas duas situações em que ocorrem no curso de Licenciatura em Enfermagem: o contexto da sala de aula e o acompanhamento dos estudantes do curso de auxiliar e técnico em enfermagem durante o estágio clínico.

O portfólio foi instrumento integrante do processo de avaliação da disciplina e foi critério de seleção dos portfólios apresentar as duas atividades descritas acima.

Através de uma leitura exaustiva, as narrativas obtidas de cada portfólio foram analisadas a luz dos níveis de reflexão propostos por Sá-Chaves, descritas anteriormente.

\subsection{CONSIDERAÇÕES ÉTICAS}

Essa dissertação é um recorte do Projeto "Avaliação da formação docente em Enfermagem na perspectiva de docentes e de licenciandos", inscrito e aprovado na Plataforma Brasil sob o Parecer no 145.091 (Anexo 1).

O projeto de pesquisa foi submetido à apreciação da Diretoria, à Comissão de Ensino e Pesquisa e ao Comitê de Ética em Pesquisa da Escola de Enfermagem da USP.

A pesquisa foi dispensada de TCLE devido a sua natureza documental. Foi garantido o anonimato de todos os estudantes, bem como o sigilo de informações referentes às instituições, docentes e demais pessoas citadas nos portfólios. 
8 APRESENTAÇÃO E DISCUSSÃO DOS RESULTADOS 


\section{APRESENTAÇÃO E DISCUSSÃO DOS RESULTADOS}

Apesar do portfólio caracterizar-se como instrumento de avaliação do estágio curricular supervisionado, nem todos os licenciandos o apresentaram de forma completa. Dos 43 licenciandos da turma, 28 completaram seus portfólios com as duas atividades descritas.

As narrativas relacionadas à prática pedagógica vivenciada durante o estágio curricular supervisionado e apresentadas nos portfólios dos licenciandos foram analisadas quanto aos níveis de lógica reflexiva. As narrativas foram analisadas quanto aos três níveis de reflexão propostos por Sá-Chaves (2000).

A seguir serão apresentados os níveis de reflexão identificados em cada atividade proposta e suas características.

\subsection{ATIVIDADE "DESCRIÇÃO REFLEXIVA DA AULA TEÓRICA MINISTRADA"}


Figura 6: Atividade - Descrição reflexiva da aula teórica ministrada

DESCRIÇÃO REFLEXIVA DA AULA TEÓRICA MINISTRADA

Analise os tópicos abaixo relacionados ao seu Plano de aula

\begin{tabular}{|c|c|}
\hline Tema da aula & $\begin{array}{l}\text { - qual o critério utilizado para a escolha do tema de } \\
\text { sua aula. }\end{array}$ \\
\hline $\begin{array}{l}\text { Objetivos } \\
\text { Educacionais } \\
\text { e conteúdos }\end{array}$ & $\begin{array}{l}\text { - descreva como esses itens foram planejados; } \\
\text { aponte qual concepção pedagógica foi adotada } \\
\text { considerando as características dos alunos, já } \\
\text { identificadas. }\end{array}$ \\
\hline $\begin{array}{l}\text { Organização } \\
\text { do Tempo }\end{array}$ & $\begin{array}{l}\text { - descreva e justifique o tempo que utilizará para } \\
\text { cada parte de sua aula. }\end{array}$ \\
\hline $\begin{array}{l}\text { Estratégias } \\
\text { de Ensino }\end{array}$ & $\begin{array}{l}\text { - descreva sua estratégia de ensino e explique sua } \\
\text { relação com o público alvo, com os objetivos e } \\
\text { conteúdos propostos. }\end{array}$ \\
\hline $\begin{array}{l}\text { Processo de } \\
\text { Avaliação }\end{array}$ & $\begin{array}{l}\text { - Relate que estratégias você utilizou para } \\
\text { verificaçáo da aprendizagem dos alunos a curto, } \\
\text { médio e/ou longo prazo e se utilizou algum } \\
\text { instrumento ou estratégia de avaliação de sua aula } \\
\text { - anexe se necessário. }\end{array}$ \\
\hline $\begin{array}{l}\text { Reflexão } \\
\text { sobre essa } \\
\text { experiência }\end{array}$ & $\begin{array}{l}\text { - Faça uma breve reflexão sobre essa experiência, } \\
\text { destacando aspectos positivos, negativos e/ou } \\
\text { outros comentários que acharem pertinentes. } \\
\text { Descreva o que você faria para melhorar suas } \\
\text { próximas aulas. }\end{array}$ \\
\hline
\end{tabular}

Autor: Débora Rodrigues Vaz

Nesta atividade (Figura 6), dos 28 portfólios analisados, todos apresentaram narrativas em nível técnico de reflexão, 22 em nível crítico e 15 em nível metacrítico, conforme Gráfico 1.

Gráfico 1: Níveis de reflexão - Atividade "Descrição Reflexiva da aula teórica ministrada".

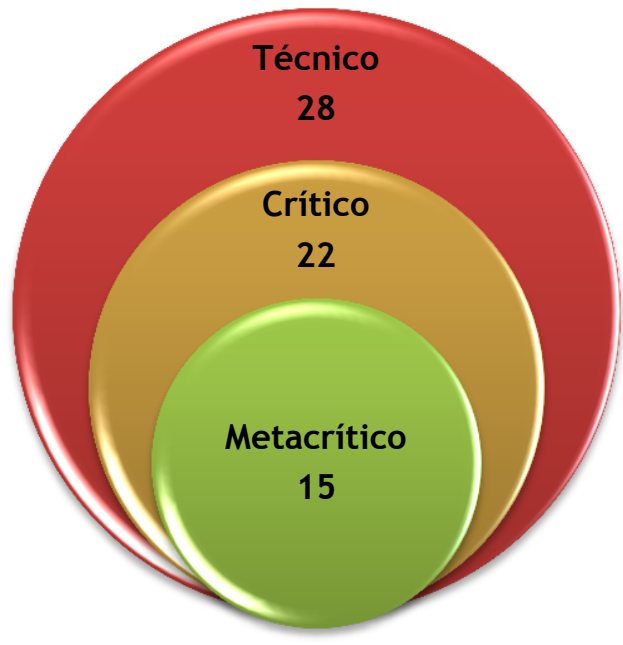

Autor: Débora Rodrigues Vaz 
Os fatos narrados por todos os licenciandos foram sobre as aulas ministradas durante o estágio, que aconteceram em diversas escolas e sob a supervisão de diferentes professores supervisores, porém, mesmo tendo a Rota de Aprendizagem para a elaboração do portfólio, cada licenciando enfatizou em suas narrativas o que the foi mais significativo.

\subsubsection{As narrativas em nível técnico}

Para Sá-Chaves (2000), nas narrativas em nível técnico os estudantes apresentam os fatos que consideram importantes para o desenvolvimento de seu conhecimento profissional e incluem elementos da ocorrência destes como, por exemplo, o tempo, o espaço, os participantes, os recursos, etc. Tais detalhes situam o estudante dentro do campo em que vivenciou o estágio e também suas relações com colegas e professores supervisores de estágio, como encontrados nas narrativas a seguir:

Hoje ministrei uma aula teórica para a turma de técnicos de enfermagem. O tema da aula foi Vacinas e Rede de

Frio, escolhido pela professora, que deu 3 temas para mim e minhas amigas, distribuídos em dois dias (dias 10 e 14/10). Devido à melhor adequação do nosso horário e dos dias em que poderíamos ministrar a aula, escolhi este tema e este dia (14/10). (P4)

No dia 22/09 a licencianda ministrou a primeira aula teórica com o tema: Auditoria em Enfermagem (4hs), que foi escolhido após a reflexão junto a professora, na qual, buscava atender tanto a vontade da aluna em buscar um tema de seu interesse como algo que estivesse relacionado com a disciplina (Organização do Processo de Trabalho)(P7)

Neste nível as narrativas possuem características descritivas, assim os licenciandos contam suas vivências mais significativas em relação aos tópicos solicitados na Rota de Aprendizagem:

Pude escolher o tema, o dia e o horário, e utilizei como critério, a disponibilidade de aulas ao sábado, visto que trabalho em período integral. Considerei também o tempo que deveria levar para o preparo da aula e a 
afinidade do tema. Com isso, definimos que ministraria aula no sábado, do dia 15/10/2011, sobre o tema "Sistema Digestório - Anatomia, Fisiologia e Cateterismo

Gástrico). (P20)

[...] utilizei a exposição dialogada e a dinâmica de grupo. Ambas as estratégias mais utilizadas atualmente, porém que me proporcionam organização e segurança no momento de preparação da aula e da própria aula. (P18)

Algumas narrativas revelaram algumas opiniões e justificativas, 0 que também as categorizam em nível técnico, por suas características descritivas:

Gostaria de ter feito uma aula mais dinâmica, menos teórica, mas o tema não me proporcionou ideias para isso. Gostaria de ter usado outras estratégias de ensino, como uma discussão em grupo, um estudo de caso ou uma simulação como, por exemplo, uma dramatização com a turma, mas também não havia tempo suficiente para isso, já que a docente ainda daria outras aulas e faria uma atividade com a turma depois disso tudo. (P3)

Após contextualizarem o campo de estágio, os licenciandos continuaram suas narrativas em relação ao tema da aula e os critérios para sua escolha.

Foi observado que nem sempre os licenciandos tiveram oportunidade de escolha do tema da aula a ser ministrada, mas quando a tiveram decidiram por temas com os quais tinham mais familiaridade e domínio, com a justificativa de tal fato trazer mais segurança e facilidade ao planejamento da aula. Para Shulman (2005, p. 12) quando o professor domina o tema que está ensinando, consegue transmitir com mais facilidade aos estudantes o que realmente é essencial sobre aquele conteúdo e também explicar de diferentes formas os mesmos conceitos ou princípios. Para o autor, ter um conhecimento aprofundado sobre o conteúdo é entendido como uma característica fundamental para o ensino. Como exemplificam as narrativas a seguir:

O principal critério que utilizei para escolha do tema da aula foi a proximidade com o assunto, pensando que poderia facilitar para eu preparar a aula e também me sentir mais segura para ministrá-la. (P14) 
O critério utilizado para a escolha do tema foi, um consenso entre os temas disponíveis pela grade da disciplina, com o meu domínio e segurança a cerca do que seria apresentado. (P23)

Outro critério para a escolha do tema foi ter tempo para se dedicar ao planejamento da aula. As narrativas a seguir, apesar de explicarem os motivos da escolha do tema, são essencialmente descritivas:

Procurei primeiramente por um tema que mais domino, mas infelizmente já tinham sido escolhidos ou ministrado pela professora. Então escolhi ministrar aula no bloco de Saúde da Mulher pelos seguintes motivos: ele ocorreria depois que acabasse meu estágio curricular (para ter mais tempo de dedicação) e tinham temas que apesar do meu pouco domínio, as aulas que tive na graduação iriam ajudar muito, por terem sido bem dinâmicas. (P10)

[...] a escolha do tema da aula não obedeceu a nenhum critério. No campo, procurei pela professora, a qual tinha

os horários de aulas que mais se adequavam à minha disponibilidade, e ela me apresentou as aulas que ainda deveriam ser ministradas e não tinham sido assumidas por nenhum licenciando. Optei pela aula sobre Necessidades Nutricionais e Dietoterapia por estar escalada para um dia em que eu estava de folga no trabalho e pude dedicar meu dia à aula. (P18)

As narrativas em nível técnico a seguir demonstraram que em muitos casos o tempo destinado as aulas foi pré-estabelecido pelos professores supervisores, o que algumas vezes limitou a utilização de estratégias que necessitam de mais tempo:

Foi uma aula com duração de 120 minutos, pois a professora queria ainda no mesmo dia entregar um trabalho de calculo de medicamento e corrigir junto com os alunos antes deles fazerem a prova final. (P24)

Gostaria de ter utilizado dinâmicas de grupo como uma estratégia de ensino adicional, porém o conteúdo da aula era extenso e o tempo era limitado em duas horas, não podia exceder este tempo, pois os alunos teriam aula em seguida com outra aluna da licenciatura. (P19)

Algumas dificuldades em relação ao planejamento do tempo também foram narradas ao colocar o Plano de aula em prática. Apesar das narrativas a seguir identificarem o motivo pelo qual o tempo 
planejado foi insuficiente para a conclusão das atividades propostas, não avançaram além da descrição:

Como processo de avaliação dos alunos, planejei ao final da aula, questionar os alunos, sobre os principais pontos apreendidos em aula, mas acabou não dando tempo, devido ao fato dos alunos terem questionado várias vezes durante o desenvolvimento da aula, acabou não dando tempo de concluir as atividades de avaliação e devolutiva prática do procedimento. (P20)

Tive que demonstrar a técnica de cateterismo gástrico apressadamente e não sobrou tempo para a devolutiva $e$ nem para avaliação da aula e dos alunos. (P20)

\begin{abstract}
A influência das experiências no desempenho do licenciando também foram narradas. Para Tardif (2000, p. 15) os estudos dos saberes profissionais dos professores não pode ser reduzido ao estudo da sua cognição ou do seu pensamento. Para a autora
\end{abstract}

os professores dispõem, evidentemente, de um sistema cognitivo, mas eles não são somente sistemas cognitivos, coisa que é muitas vezes esquecida! Um professor tem uma história de vida, é um ator social, tem emoções, um corpo, poderes, uma personalidade, uma cultura, ou mesmo culturas, e seus pensamentos e ações carregam as marcas dos contextos nos quais se inserem.

Todas as experiências anteriores, seja ela qual for, podem ter algum tipo de influência no desempenho do professor. Nas palavras de Nóvoa (2009, p. 6)

Ao longo dos últimos anos, temos dito (e repetido) que o professor é a pessoa, e que a pessoa é o professor. Que é impossível separar as dimensões pessoais e profissionais. Que ensinamos aquilo que somos e que, naquilo que somos, se encontra muito daquilo que ensinamos. Que importa, por isso, que os professores se preparem para um trabalho sobre si próprios, para um trabalho de autorreflexão e de autoanálise.

A seguir narrativas em nível técnico que descreveram a relação entre experiências anteriores e desempenho:

Para traçar os objetivos e conteúdos que abordaria, me baseei no que vivencio com os auxiliares de enfermagem onde trabalho; no que é extremamente necessário ser do conhecimento deles; no que tais assuntos acrescentariam para sua função de auxiliar. (P18) 
O interesse, relatado pela licencianda se baseou em dois fatores: em critério pessoal, pois a licencianda faz parte de programa de aprimoramento em uma instituição hospitalar particular de grande porte da cidade de São

Paulo, sendo assim, o processo de "Acreditação" faz com que a auditoria se torne uma prática constante em seu dia-dia, além do fato de critérios de "glosas de convênios" e cobranças de procedimentos; em critério de perfil dos alunos, percebe-se que a maioria trabalha em hospital público e quem está desempregado passa em estágio nessas instituições, sendo assim, discutir um tema que parece não estar incluso na esfera pública se torna interessante, reflexivo, discutível, informativo e colaborativo para um atender tanto os objetivos de uma disciplina de Organização de processo de trabalho como também para uma formação de cidadãos críticos na importância de entender os gastos e o "valor" do dinheiro público. (P8)

A partir disso, incentivei para que eles refletissem sobre as ações de um auxiliar de enfermagem frente ao controle e alterações dos sinais vitais para a correta tomada de decisão. Acho essa uma questão muito importante e precisaria ser trabalhada com estratégias que melhor incorporassem o domínio atitudinal dos alunos. (P14)

\section{Algumas narrativas descreveram a oportunidade de colocar em prática algumas teorias de aprendizagem, temas que foram contemplados também em aulas virtuais:}

Sei que é um tema bastante cansativo então procurei não ler todo o conteúdo dos slides, mas discutir com eles sobre as experiências que eles vivenciaram sobre vacinação, através de uma abordagem cognitivista, em que o meu papel seria o de fazer da minha aula um ambiente que facilitasse a troca de experiência e cooperação entre os alunos; visto que é um público que já concluiu o curso de auxiliar de enfermagem, portanto alguns já têm experiências profissionais na área da Enfermagem. (P4)

Acredito que a Teoria da Aprendizagem Significativa colabora de maneira impar na aula, confesso a dificuldade de relacionar a teoria com a prática por ter uma limitada experiência na área, sendo estudante de graduação, entretanto encaro também como um desafio ao ministrar a aula. (P8)

O levantamento dos conhecimentos prévios, o uso da problematização e a utilização de estratégias de simulação também foram fatos descritos pelos licenciandos. Para Freire (1987, p. 41) uma educação problematizadora organiza-se em torno do contexto dos estudantes, onde estes "vão desenvolvendo o seu poder de 
captação e de compreensão do mundo que lhes aparece, em suas relações com ele, não mais como uma realidade estática, mas como uma realidade em transformação, em processo." A seguir narrativas que exemplificam o descrito acima:

Na introdução da aula utilizei a técnica da tempestade de idéias (brainstorming) em que os alunos têm um espaço para relatar sobre o que conhecem sobre Central de Material e esterilização, bem como se conhecem algum método de esterilização. Esta técnica favorece que possamos levantar os conhecimentos prévios dos alunos, que é uma das etapas propostas pela metodologia dialética na fase de síncrese. (P11)

[...] procurei criar um ambiente de trocas de experiências, penso que isso pode ser muito explorado, pois na área da saúde, há vários exemplos tanto pessoais, quanto familiares. (P8)

Como a aula havia ficado muito carregada de informações e de fotos pesadas e tristes, procurei pensar em alguma estratégia que deixasse a aula menos pesada e cansativa para os alunos.

Então me veio a ideia de utilizar algum tipo de simulação, e a partir disso montei meu plano de aula. [...] Me surpreendi com a atuação das alunas voluntárias (solicitadas para a simulação),

pois elas seguiram direitinho o proposto e encararam com

seriedade. Quando acharam necessário fizeram perguntas além do que estava no script, tornando a simulação mais real.

(P10)

O entendimento de que o conhecimento se dá como um processo de crescimento e construção tanto do estudante quanto do próprio licenciando, também mostrou-se evidente. Para Vasconcellos (2000, p. 57) "as ciências pedagógicas contemporâneas demonstram que o sujeito só adquire o conhecimento quando, num processo ativo (seja motor, perceptivo, reflexivo, intuitivo), reconstrói o objeto de conhecimento." Como segue a narrativa de P18:

A segunda parte foi planejada como a maior, na qual ocorreria a construção do conhecimento, tanto para os alunos como futuros auxiliares de enfermagem, como para mim como futura docente. [...] Procurei mostrar aos alunos que não conseguimos absorver tudo que é tratado em uma aula e que depende de nós, buscar e construir nosso conhecimento fora da sala de aula também. (P18)

Preocupações, como ter estudantes trabalhadores e adultos, demonstram que os licenciandos conhecem algumas das 
características dos estudantes dos cursos de auxiliar e técnico em enfermagem, além de princípios da Andragogia. Além de participar no desenvolvimento cognitivo, afetivo e social dos estudantes, "o professor deve ter ainda formação política para entender, criticar e procurar soluções para os diferentes problemas vivenciados no sistema educacional" (Barreiro, Gebran, 2006, p. 88). Algumas narrativas descreveram tais preocupações e como elas influenciaram no planejamento de suas aulas:

Considerando a faixa etária dos alunos em torno de 30 anos, e alunos que trabalham e que não despendem muito tempo para o estudo, pensei que uma aula de forma expositiva, mas que convidasse $o$ aluno a participar e interagir fosse a melhor maneira de explorar o conteúdo. (P6)

Adaptei o conteúdo à necessidade da turma, ou seja, considerei o fato de serem alunos do curso de auxiliar de enfermagem, sem experiência na área de saúde. Tomei cuidado em adaptar a linguagem ao público alvo, para facilitar a aprendizagem deste. (P20)

[...] planejei a aula de acordo com o perfil dos estudantes (faixa etária de 20 a 50 anos), levando em consideração o fato de ser uma turma em que grande parte dos alunos trabalha ou já trabalhou em hospitais e o horário em que foi ministrada a aula (das 21 às 23 horas). Procurei usar os conceitos da andragogia, principalmente o uso de experiências próprias e relatos dos alunos para reforçar a atenção no tema, pois a aula acabou tornando-se mais dinâmica e mais participativa. (P28)

O envolvimento prévio com a turma e com os professores supervisores também foi descrito como fator facilitador no desempenho do licenciando, como nas narrativas a seguir:

A aula foi ministrada na turma de auxiliar de enfermagem que eu havia acompanhado alguns alunos durante $o$ estágio. Ter esse envolvimento prévio facilitou bastante a nossa interação durante a aula. (P10)

Para mim os principais aspectos negativos foram o pouco contato que tive com a professora, com os alunos e com o conteúdo que estavam aprendendo anteriormente (P14)

Quanto à avaliação dos estudantes, as narrativas descreveram situações que demonstram um entendimento mais abrangente sobre o conceito de avaliação, incluindo a importância de sua função 
formativa. Para Bloom (1983) a avaliação formativa ocorre durante o processo de ensino-aprendizagem e pretende posicionar o estudante em relação a sua aprendizagem e propor soluções a partir da identificação de alguma dificuldade, a fim de alcançar determinado objetivo. Fornece um feedback a professores e estudantes, com objetivo de individualizar o atendimento ao estudante e solucionar possíveis falhas na aprendizagem.

Hadji (2001, p. 20) ressalta que a avaliação formativa "situa-se no centro da ação de formação" e deve contribuir para uma "boa regulação da atividade de ensino", informando os dois atores principais deste processo:

O professor, que será informado dos efeitos reais de seu trabalho pedagógico, poderá regular sua ação a partir disso. O aluno, que não somente saberá onde anda, mas poderá tomar consciência das dificuldades que encontra e tornar-se-á capaz, na melhor das hipóteses, de reconhecer e corrigir ele próprio seus erros.

As narrativas em nível técnico a seguir, demonstraram o exposto acima:

Para a avaliação da aula, elaboramos algo que pensamos que não fosse tão pesado para os alunos, levando em conta que a aula teria um conteúdo denso e cansativo. Então, fizemos uma discussão com base em exercícios que apresentariam situações muito comuns que eles viveriam durante o estágio na sala de vacinas em saúde coletiva. Pensamos em algo de modo bem informal, para que pudéssemos ter o retorno deles e pudéssemos verificar se eles realmente aprenderam o conteúdo. Para isso, promovemos uma discussão com toda a sala em que todas as dúvidas que fosse surgindo, os próprios alunos iam respondendo e um ajudando o outro a entender. (P15)

Para verificar a aprendizagem tanto ao final da aula quanto durante a mesma, utilizei perguntas, questionamentos relacionados aos temas, tentando sempre focar nas relações que os alunos tinham da prática com a teoria. (P3)

$\mathrm{Na}$ narrativa a seguir percebe-se a visão do erro como possibilidade de mudança, de aprimoramento e a preocupação de transmitir esta visão aos estudantes, deixando-os mais a vontade para errar e aprender: 
Para verificar a aprendizagem dos alunos realizei perguntas faladas para eles, esperava a resposta deles, às vezes eles ficavam mais tímidos para responder, mas com um incentivo, por exemplo, explicava que podiam dar uma resposta simples e estaria correto, que não havia certo ou errado, um ou dois começavam a dar algumas respostas e então os outros também se sentiam confortáveis para responder e então, complementavam a resposta, quando eles completavam a resposta eu mostrava/confirmava a resposta,mostrando em slide. (P2)

A oportunidade de uma avaliação sobre o seu próprio desempenho em sala de aula foi observada em algumas narrativas, evidenciando a importância desse feedback:

Como processo de avaliação da aprendizagem dos alunos, o estudo de caso em grupo foi o recurso utilizado, pois permitiu mais do que a avaliação dos alunos, a avaliação da minha própria aula através das dúvidas ou equívocos que os alunos traziam. (P6)

Nas narrativas a seguir os licenciandos demonstram boa aceitação às dificuldades relacionadas aos seus desempenhos apontadas por supervisores e estudantes, mas possuem características descritivas:

Esta etapa serviu também para avaliar a aula ministrada, a organização do conteúdo e a minha postura como docente. Os alunos avaliaram positivamente a forma como a aula foi organizada, gostaram da exposição sobre o tema, como crítica apontaram que eu não me movimentei muito durante a aula (P19)

A professora elogiou minha aula e como comentário disse que eu devia falar mais devagar, possivelmente porque eu estava nervosa e como os alunos dessa sala eram muito interessados, eles me pausavam sempre pedindo para retomar um conceito. (P21)

Algumas narrativas relacionadas à autoavaliação e autopercepção do licenciando em relação ao seu desempenho em sala de aula, demonstraram apenas potencialidade para narrativas em nível crítico, pois não mencionaram fatos concretos que demonstrassem como o licenciando chegou a tal conclusão. Na narrativa a seguir, o licenciando relata que a experiência foi válida, que esta aula foi bem diferente da outra e que conseguiu lidar com os imprevistos, mas não evidenciou os motivos, o que não nos permite analisá-la como narrativa em nível crítico: 
No geral, a experiência foi muito válida para o meu aprendizado. Foi muito diferente da outra aula que ministrei no semestre anterior com uma turma muito menor. Embora muitas coisas não tenham acontecido conforme planejado foi pra mim uma surpresa conseguir lidar com os imprevistos e ainda assim trabalhar dentro dos objetivos planejados. (P14)

Apesar de não solicitada explicitamente na Rota de Aprendizagem, a relação entre licenciando e professor supervisor de estágio foi amplamente relatada. Segundo Grilo e Machado (2005, p. 35) o "supervisor deve contribuir para a criação de um ambiente de colaboração em que a liberdade para fazer escolhas seja promovida e em que o formando seja apoiado no desenvolvimento de uma linguagem pessoal e profissional própria que fundamente suas escolhas". Muitas narrativas em nível técnico mostraram como a relação de colaboração auxiliou ou não no desempenho dos licenciandos:

A professora também se relacionou comigo e com a sala ajudando com exemplos mais práticos para explicar melhor um tema tão teórico e abstrato para os alunos. (P3)

A professora responsável, não acompanhou a aula. Quem acompanhou foi a professora (nome), docente substituta. Esta me auxiliou a responder alguns questionamentos dos alunos sobre assuntos que eu não dominava. (P20)

Quanto ao conteúdo, senti a necessidade de apoio da professora (nome) no decorrer da aula, diante de alguns questionamentos dos alunos. (P18)

A professora permaneceu o tempo todo na sala, porém ela estava corrigindo provas. (P24)

Momentos em que foi permitido ou não ao estudante exercitar certa autonomia também foram narrados nos portfólios. Como afirma SáChaves (2000) a autosupervisão do formando se torna progressivamente dominante à medida que o controle na relação formativa se desloca na direção do estudante:

Os objetivos educacionais e conteúdo foram propostos em conjunto, pela professora responsável pela turma e por mim. A partir das informações fornecidas pela professora sobre aquilo que deveria ser abordado na 
aula, conversamos e introduzimos outros assuntos e sugeri outros conceitos para serem trabalhados. (P2)

O tema foi escolhido pela professora apenas decidi o aprofundamento a ser realizado dentro do tema, optei por enfocar principalmente os riscos biológicos descritos na Norma Regulamentadora n. 32 (P12)

A participação de mais de um licenciando na sala de aula também foi descrita nos portfólios. Muitas vezes eles dividiram atividades e participaram em colaboração e cooperação. Para Sá-Chaves (2000), nas palavras de Grilo e Machado (2005, p. 36)

"admite-se que os formandos possam estabelecer entre si relações supervisivas que possam facilitar a cada qual os processos de autoformação, com as vantagens da ausência de barreiras, constituindo um espaço decodificador da ação num clima de suporte, de ajuda crítica, de solidariedade e de desenvolvimento mútuo, consciente e partilhado".

Para a Sá-Chaves (2000, p. 35) a contribuição desta colaboração não deve ser negligenciada, pois "trata de um tipo de relação que, pela sua natureza própria, pode apresentar uma especificidade que enriquece e amplia o quadro de hipóteses formativas possíveis." Os portfólios a seguir trazem narrativas sobre essas relações, mas P10 mostra como ela pôde ser positiva:

A aula teórica foi ministrada junto com mais uma licencianda, pois não havia aulas suficientes na disciplina de Saúde Coletiva para todas as licenciandas, por ser uma disciplina curta com um número pequeno de aulas. (P15)

Tiveram perguntas que eu não sabia muito bem quais eram as resposta, e nessa hora algumas licenciandas que estavam acompanhando a minha aula e que sabiam responder me ajudaram.

Além de me ajudar com algumas perguntas, elas fizeram comentários sobre as patologias e experiências dos estágios da graduação. (P10) 


\subsubsection{As narrativas em nível crítico}

Para Sá-Chaves (2000) as narrativas em nível crítico envolvem reflexão sobre os fatos narrados nos episódios, identificando as suas múltiplas e possíveis causas, consequências e significados. Estas características podem ser observadas nas narrativas abaixo:

No momento de ministrar a aula, acredito que não atingimos todos os objetivos da aula e também não conseguimos utilizar o tempo que havia sido proposto, justamente por falta de participação da turma e talvez por uma inexperiência nossa em não saber como lidar muito bem com essa situação. (P15)

Acredito que isso pode ter acontecido por conta da estratégia de ensino que utilizamos. Talvez se tivéssemos elaborado algo mais criativo, os alunos se sentiriam mais motivados para participar. (P15)

Segundo a autora, este nível envolve também a reflexão sobre o "papel dos contextos na determinação dos fatos, sobre as funções e papéis desempenhados e sobre as concepções que os sustentam e ainda sobre novos papéis e novas funções que poderiam ser desempenhados à luz de novas concepções". Os licenciandos começam a refletir sobre os acontecimentos, percebendo a influência do contexto e de todos os intervenientes envolvidos. As narrativas a seguir apresentam algumas destas características:

Acho que foi uma ótima experiência, pois observo que a cada aula que ministramos nos atentamos mais a alguns aspectos e aos poucos conseguimos incorporar os preceitos da Metodologia Dialética e da Teoria da Aprendizagem Significativa, de modo que no término do planejamento da aula nos perguntamos como seria uma aula que não incorpore os aspectos considerados nessas teorias? Acredito que seria uma aula com o aluno exercendo um papel passivo na construção do conhecimento e que provavelmente não alcançaria a aprendizagem significativa, perpetuando assim a ideia do modelo tradicional, o que vai de contramão com os nossos objetivos. (P11)

Ela (a professora) foi essencial para o planejamento uma vez que acompanha os alunos desde o início do curso, então sabe todas as disciplinas que eles já tiveram,como tiveram e, além disso, conhece bem os alunos, suas características, facilidades e dificuldades. (P2) 
Alguns portfólios apresentaram reflexão em nível crítico sobre a importância de dominar o conteúdo para bem desenvolvê-lo e ter êxito em uma aula:

Considero um desafio ministrar uma aula por diversos motivos. Um deles é transmitir o conhecimento de algo que você não possui familiaridade, então foi necessário primeiro muito estudo e pesquisa para aprender sobre o tema, e somente depois disso, começar a planejar como seria a aula. (P2)

É importante ter o embasamento teórico antes do planejamento da aula, desta forma pude avaliar qual seria a melhor estratégia de ensino para aquele perfil de alunos, refleti sobre o processo de ensinagem do conteúdo. (P19)

Vi que para eu me preparar bem para ministrar uma aula é necessário mais do que o simples conhecimento do tema, é preciso também um estudo mais aprofundado, uma boa pesquisa e sobretudo um bom planejamento (P27)

Questionamentos em relação ao sucesso da aula, apontando suas possíveis causas também apareceram em alguns portfólios. As narrativas em nível crítico a seguir mostram como as experiências profissionais e de vida também podem influenciar na abordagem do conteúdo:

Mas por que essa aula fez tanto sucesso?! Desde o início da graduação me dedico a pesquisar sobre esse assunto (juntamente com as Professoras), além disso tenho diabetes mellitus tipo 1 há 5 anos, o que facilita muito na hora de dar exemplos e falar sobre as experiências do paciente. (P13)

Apesar de já ter desenvolvido esta atividade em método I, considerei que agora, devido ao meu amadurecimento e complementação com método II, teve uma melhora na qualidade da aula realizada. (P20)

Identificar as consequências de determinados fatos confere à narrativa um nível crítico de reflexão. A seguir P10 reflete sobre as consequências de se dominar o tema:

Continuo achando que ministrar aulas requer que o professor tenha um mínimo de experiência, uma vez que os alunos trazem bastante dúvidas e curiosidades. Além disso, ministrar aulas com temas que dominamos nos 
deixa mais seguro e o aluno percebe quando existe essa segurança quando o conteúdo é transmitido. (P10)

Alguns licenciandos demonstraram reflexões em nível crítico acerca do alcance dos objetivos da aula, tentando encontrar suas causas. "O estagiário é, antes de tudo, um professor em processo de formação e, portanto, não podemos partir do princípio de que ele irá sempre acertar em suas aulas." (Carvalho, 2012, p. 74). A reflexão do licenciando sobre o que deu certo e o que não deu, sobre seus acertos e erros, suas dificuldades e facilidades, estão representadas nas narrativas a seguir:

Durante a aula, percebi que os objetivos estabelecidos estavam sendo alcançados e senti falta de alguns que no momento do planejamento não tive a criatividade para traça-los. (P18)

Nessa hora fiquei bem contente com essas dúvidas (apresentadas pelos alunos), pois depois de todo trabalho que tive em preparar a aula senti que eles tiveram confiança no meu conhecimento e no que eu havia estudado. (P10)

Ao final da aula não tive a sensação de dever cumprido, mas com sensação de derrota muito grande. Com esta aula ficou evidente que sem a participação dos alunos a aula não é nada e não progride, pois se estes não interagem, questionando e debatem durante a aula esta não evolui, tornando-se apenas mais um monólogo. (P26)

Algumas narrativas trouxeram reflexões em nível crítico sobre a utilização de diferentes estratégias de ensino e reflexão quanto a consequências e resultados de determinadas escolhas:

É importante como docente considerar que nem sempre a estratégia de ensino proposta irá funcionar com os alunos, devemos ter um jogo de cintura para alterar a estratégia e ter maturidade para avaliar a aula e elencar as alterações que são necessárias ser realizadas. Não podemos esquecer da importância de ser um professor reflexivo, analisar a nossa postura como docente, os aspectos que podem ser melhorados para facilitar a construção do conhecimento. (P19)

Pode parecer desnecessário dizer que o processo ensino-aprendizagem é algo individual de cada aluno, no entanto, muitas vezes deixamos de lado essa individualidade relacionada ao professor, isto é, conhecendo diferentes metodologias de ensino podemos 
ver que não há uma metodologia melhor ou pior, mas sim a metodologia que se adapta ao tipo específico de aluno e de professor. (P13)

Para Darsie (1996, p. 95) a reflexão e a tomada de consciência por parte dos licenciandos de "situações por eles vividas como aprendizes, são momentos privilegiados para a reflexão sobre a prática, assim como a reflexão sobre a aprendizagem a partir de um novo modelo de ensino os leva à reflexão e à crítica do velho modelo". A seguir narrativas em nível crítico que exemplificam o exposto:

Sempre critiquei um pouco professores que utilizavam slides, ainda estava presa aquela mentalidade de ensino médio em que os professores usavam lousa e giz, no entanto me surpreendi quando fui preparar a aula que ministrei. Não consegui encontrar outra maneira que não o famoso e odiado (por mim mesma) Power Point. (P13)

No início da aula percebi os alunos imóveis, como se esperando a transmissão de informações de forma passiva, sem interação, o que dificultou minha atuação como facilitadora do processo ensino-aprendizagem e não como centro do conhecimento. [...] fica claro que os alunos estão habituados a metodologia tradicional de ensino e reagem com desconfiança a atividades como a dinâmica de grupo, pois participaram sem compreender muito bem a finalidade da atividade até que eu a explicasse com extrema clareza, ou seja, não estão acostumados a interagir com os outros alunos e com os professores a fim de desenvolverem por si mesmos suas conclusões e aprendizagens. (P18)

O fato de se ter ou não um contato prévio com os estudantes também fez alguns licenciandos refletirem criticamente sobre o resultado de suas aulas, fazendo-os avaliar este contato. Nas narrativas em nível crítico eles refletem sobre estas implicações:

Outro motivo é não conhecer muito bem os alunos, dificulta a o planejamento da aula, ficava me questionando: o que deixará eles mais motivados? Como eles assimilarão melhor esse novo conhecimento? Será que já tem conhecimento disso e então posso relacionar com isso? Será que dessa maneira entenderão a importância desse assunto? Mas após trocar informações com a docente que os acompanha e assistir duas aulas, ficou um pouco mais claro o perfil dos alunos, que como já descrevi anteriormente são participativos, e mais interessados quando o tema se relaciona a realidade, facilitando o planejamento da aula. (P2) 
Percebi que isso (conhecer pouco os alunos e a professora) não foi suficiente para me ajudar a entender o processo que os alunos passavam, porque acredito que para isso um contato mais próximo precisava ter sido criado, o que foi um pouco difícil dentro do cronograma da disciplina e também pelo fato de alguns alunos da licenciatura, como eu, tivemos que trocar o campo de estágio. (P14)

Dificuldades no desenvolvimento da aula levaram alguns licenciandos a perceber a importância das experiências negativas na própria construção do conhecimento, como observado nas narrativas em nível crítico a seguir:

acredito que por estar em fase final do curso de licenciatura em enfermagem, esta experiência agregou somente pontos positivos à minha formação como professora. Mesmo os pontos negativos vivenciados no processo de ministrar esta aula teórica trouxeram aprendizados para mim, o que os torna pontos positivos indiretamente. (P18)

Apesar disso, a experiência foi boa para que pudéssemos perceber que nem sempre o planejado acaba dando o resultado que esperávamos e temos que ter criatividade para lidar com essas situações. (P15)

Alguns portfólios apresentaram uma reflexão em nível crítico sobre o "ser docente", o papel do professor e a identidade com a profissão. Para Simão (2005, p. 98), o portfólio reflexivo proporciona "um diálogo do estudante consigo próprio, como uma forma de organizar o pensamento e a aprendizagem", pois promovendo a autonomia do estudante na gestão da aprendizagem, torna-o mais participativo e motivado, levando-o a produção e encontro de sentido(s). Abaixo como P6 e P8 refletiram:

A experiência de ter ministrado esta aula foi, para mim, muito positiva: percebi que o professor ainda é visto pelo aluno como aquele que tem todo o conhecimento, e que o papel de facilitador precisa ser enfatizado na prática da docência; notei, também, que os conteúdos das aulas precisam ser distribuídos de forma adequada, as características destes alunos não permitem a estes aulas tão complexas e cheias de conceitos, é necessário rever quais conteúdos são realmente importantes para a formação profissional. (P6)

Esta é a segunda experiência de ministrar uma aula, como aspectos positivos reconheço o contato prévio com a turma, que me fez sentir mais confiante, acredito que 
aspectos negativos, foi o curto tempo para elaboração da aula, penso que poderia ter utilizado outras estratégias de ensino, uma vez que o tema era abrangente e possível de avançar nos recursos didáticos. Sem dúvida esta vivencia reforçou a identificação da identidade do docente em minha vida. (P8)

Para Moreira (2010, p. 22) baseando em Nóvoa (1992)

A identidade é o lugar de lutas e conflitos, um espaço no qual se constroem e reconstroem modos de ser e de estar na profissão. Esta referência torna evidente que a construção da identidade profissional se faz, também, a partir do sentido que o profissional confere ao seu trabalho, das suas crenças e motivações, das suas disposições pessoais, de tudo o que se constitui como lugar de "afirmação" do que se quer, do que não se quer e do que se pode, enquanto professor.

Segundo Darsie (1997, p. 94) a "reflexão a posteriori sobre a aprendizagem favorece uma conexão entre o contexto da sala de aula e a história de vida pessoal, tornando possível o desdobramento e a reflexão sobre a aprendizagem e o ensino ao mesmo tempo". Para a autora é nesse momento que acontece a reflexão de sua prática e citando Schön (1992) desencadeia o processo que ele chama de "reflexão-sobre-a-ação e sobre a reflexão-na-ação", o que leva o licenciando à "reflexão-sobre-suaação ou reflexão sobre a ação de ensinar". As narrativas a seguir apresentam reflexões para além do vivenciado na aula ministrada, trazendo considerações sobre os desafios que ainda virão, caracterizando o nível crítico de reflexão:

Também não imaginava que questões tão próximas da realidade dos alunos pudessem surgir da maneira como apareceram. Por isso, também notei a importância de conhecermos quem é o público, no âmbito sócio-cultural. Trazem muito exemplos da família ou de conhecidos próximos e também de situações do trabalho e das tarefas de casa, por exemplo. Foram tantas perguntas diferentes, que refletindo agora, acho que os alunos esperam que o professor seja de fato uma "enciclopédia" de conhecimentos gerais e não apenas dos teóricos específicos. Acho que o professor pode se aproveitar disso para estimular nos alunos o "gosto" pelo saber, incentivando-os buscarem respostas para as próprias perguntas, além dos conteúdos das disciplinas, trabalhando em pró da construção de uma cultura da investigação. Acho "perigosa" essa postura do docente querer responder todas as questões! (P14) 
Ao entrar na sala de aula, confesso que fiquei bastante ansiosa por não saber como seria aceita minha metodologia proposta aos alunos e pela cobrança de passar todas as informações, mesmo sabendo que estas seriam construídas inicialmente através de minha exposição com estes alunos, porém se estenderia pelo resto de suas carreiras já que o contato com a matéria dada seria parte integrante da vida destes alunos por todo tempo de trabalho. (P17)

Como parte da minha experiência, percebi que dar aula não é apenas a ação no momento, é necessário preparála, adequar o conteúdo ao perfil e necessidades dos alunos, prender a atenção destes, motivá-los a saber mais, a questionar o tempo todo, a participar. E esse é um dos principais desafios que eu, como professora naquele momento percebi. (P24)

Os portfólios também apresentaram narrativas em nível crítico envolvendo o processo de avaliação. Para Darsie (1997, p. 93) um olhar distanciado sobre o objeto de aprendizagem permite ao licenciando "refletir sobre o mesmo, e a estabelecer confronto entre seu conhecimento prévio deste objeto e a nova aprendizagem, levando-o assim, a construção de um novo conhecimento, ou a compreender tal objeto de maneira diferente de como o via antes". Nas narrativas a seguir percebe-se esta reflexão:

Porém, percebi que poderia ter utilizado de um instrumento, ou de uma outra estratégia (dialogada, dinâmica), para receber o feedback da aula ministrada.

Planejei a aula com bastante antecedência, critério e dedicação, porém, na parte de avaliação, percebo que faltou ainda mais planejamento. (P22)

Após essa avaliação percebe-se que os seguintes itens devem ser melhorados: organizar melhor o tempo para abranger maior quantidade de alunos, criação de um instrumento avaliativo ou a iniciativa da licencianda para que os alunos avaliassem a aula, diminuição de slides $e$ utilização de recursos mais oratórios e lousa (criação do conhecimento junto ao aluno de forma escrita e não somente oral. (P7)

Para as próximas aulas eu pensaria em estratégias de ensino mais dinâmicas, tentaria diminuir o tempo de exposição dialogada, reservaria um tempo maior para os alunos realizarem a avaliação da aula. (P19)

Apesar de ser uma fase curta a avaliação foi de extrema importância para meu crescimento pessoal e profissional.

Acredito que poderia reservar um tempo maior para a avaliação, considero esta etapa fundamental para o processo de ensino-aprendizagem, pois obtemos o 
A relação entre licenciandos e professores supervisores também foi bastante aparente nas narrativas em nível crítico. Para Sá-Chaves (2005, p. 16) a voz dos estudantes que, em momentos distintos do processo, evidencia novas compreensões e novas interpretações acerca dos conceitos em análise, mas também acerca de si próprios, constitui um indicador da qualidade da supervisão desenvolvida. E essa supervisão é em alguns portfólios considerada como importante. As narrativas a seguir refletem sobre essa relação e podem ser categorizadas em nível crítico por identificarem causa e consequência da supervisão que se vivenciou:

a presença da professora da escola durante a aula colaborou para meu melhor desempenho diante da turma, uma vez que pude contar com o apoio dela para responder as perguntas dos alunos. (P18)

Por isso, não achei que eu tenha aproveitado muito a experiência, pois a professora manteve muito domínio da sala, quase como se as coisas que eu quisesse fazer tivesse que primeiro passar pela explicação dela. [...] E também achei que o domínio que a professora manteve da sala durante a aula não me ajudou a lidar com algumas dificuldades e também me aproximar dos alunos melhor. (P14)

Para Amaral (2005, p. 72) quando ultrapassados os registros descritivo simples e narrativo prático, o formando atinge um nível de reflexividade crítica, no qual o papel que desempenhou nos fatos/processos narrados é por si avaliado, esperando-se que daí decorra um repensar-se como pessoa e profissional" que caracteriza o próximo nível: o metacrítico. 


\subsubsection{As narrativas em nível metacrítico}

As narrativas em nível metacrítico tem como foco da reflexão, o "eu", assim tais narrativas falam "sobre si próprio, questionando os seus próprios papéis, funções, desempenhos e concepções, tornando-se concomitantemente ator, sujeito reflexivo e objeto da própria reflexão" Sá-Chaves (2000).

Alguns licenciandos conseguiram perceber características pessoais relacionadas à prática pedagógica que interferem no seu desempenho em sala de aula, características estas, muitas vezes difíceis de serem aceitas, principalmente para o professor em formação:

[...] dessa vez, diferente em Metodologia I, senti-me mais a vontade para ministrar a aula. Não pelo assunto, pois dessa vez estava um pouco mais complexo, mas estava mais a vontade, sem "medos e ansiedades". (P16)

Refletindo sobre essa aula ministrada: tem-se um saldo positivo, por apresentar mais aspectos positivos que negativos, Em relação a licencianda: diminuição do nervosismo por conhecer os alunos no semestre passado, melhor articulação do conteúdo com a sua experiência em prática, conseguir atrai a atenção dos alunos, uma maior desenvoltura e uma aproximação inter-pessoal com uma postura linear com alunos, utilização de estratégias de aquecimento (conhecimentoprévio) e avaliação de curto e longo prazo efetivos e práticas, criação do conteúdo junto aos alunos de forma oral perguntas e respostas. (P7)

Essa experiência foi fundamental para meu aprendizado, pois percebi como os alunos interagiram comigo durante a aula, aprendi a dizer "não sei responder essa pergunta mas posso procurar a resposta e te dizer depois", que nem sempre é fácil para o professor assumir que não sabe alguma coisa. E tive idéias novas para

fazer uma aula melhor e mais didática.

Essa sensação eu só conseguiria ter vivenciando o processo de ser professor. (P21)

Refletir de forma metacrítica trata-se, como diz Sá-Chaves (2000), de um "processo que visa conhecer-se para poder tornar-se, através do esforço próprio, da consciência clara e da coragem maior". Os portfólios a seguir mostram narrativas que caminham neste sentido, 
pois nelas os licenciandos compreenderam e aceitaram suas dificuldades, percebendo a necessidade de aprimoramento:

fiquei apreensiva quanto ao tema da aula escolhida, uma vez que acredito ser uma nutricionista a profissional ideal para ela, porém enfrentei este desafio e acredito que poderia ter estudado e me preparado melhor para o assunto (P18)

percebo que tive uma evolução da primeira aula ministrada para a segunda, visto que no primeiro semestre, no momento de ministrar a aula teórica foi muito tenso e de insegurança. Já nesta aula, estes sentimentos diminuíram significativamente, permitindo com que a aula transcorresse melhor. (P22)

considero que esta experiência trouxe um enorme ganho para minha vida profissional, pois o sentimento que vivenciei foi o de superação. Digo isto por dois fatos, por ter de abordar um tema (no caso cinco) que sempre considerei que não tivesse muito domínio e por mais uma vez ter de enfrentar a insegurança de falar em público. (P1)

O importante neste nível de reflexão é propor mudanças para o aprimoramento pessoal e da prática pedagógica, utilizando o conhecimento advindo da reflexão e refletindo ainda sobre esta mudança. Como salienta Sá-Chaves (2000) "reflectir metacognitivamente para, com o conhecimento emergente dessa reflexão, poder intervir praxicamente nos contextos e em si próprio estimulando a hipótese de devir". As narrativas abaixo exemplificam este nível de reflexão:

\footnotetext{
Acredito que ainda tenho que melhorar a minha didática em sala de aula, que sinto que é prejudicada pela ansiedade, em que falo muito depressa e muitas vezes deixo de falar alguns pontos importantes que estudei, no entanto, devido ao nervosismo passam desapercebidos. (P11)

Minha insegurança fez com que eu não me locomovesse tanto durante a aula, este ponto foi citado pelos alunos... pretendo mudar este aspecto na próxima vez que for ministrar uma aula. (P19)
}

Envolvendo também a utilização de estratégias de ensino, alguns licenciandos apresentaram narrativas em nível metacrítico, identificadas abaixo: 
Ao final desta experiência, percebi que preciso: desenvolver minha criatividade no que se refere a estratégias de ensino; preciso trabalhar minha segurança

diante dos alunos (me senti insegura em alguns momentos e considero isto normal por não ter experiência como professora, mas não posso permitir

que os demais a percebam); preciso estar melhor preparada quanto ao conhecimento do assunto que abordarei com os alunos, independente da área a que 0 assunto diz respeito, como por exemplo, nutrição. (P18)

Para melhorar minhas próximas aulas eu faria alguma brincadeira inicial com os alunos usando o tema da aula,

tentando aproximá-los mais de mim, e explicaria de forma mais simples o conteúdo (achei que a forma como apresentei o conteúdo foi um pouco difícil de acompanhar pelos alunos). E falaria mais calmamente, tentaria estar mais tranqüila durante minha explanação. (P21)

Nas próximas aulas, além de tentar controlar o nervosismo, pretendo utilizar outras estratégias de ensino. [...] Ao contrário da aula que ministrei no primeiro semestre, estava muito mais tranquila para dar aula. Acho que se deve ao fato de não ser a primeira vez $e$ porque domino melhor o assunto. (P5)

Nas narrativas em nível técnico foram descritas vivências positivas em relações supervisivas que aconteceram entre os licenciandos. Nas narrativas em nível metacrítico, houve uma reflexão em que essa relação não foi positiva. Para Sá-Chaves $(2000$, p. 36) relações supervisivas entre os licenciandos podem trazer enriquecimento à formação, porém

[...] é preciso aprofundar o conhecimento sobre os modos como os profissionais aprendem dadas as características que estes apresentam relativamente ao seu nível de desenvolvimento pessoal e profissional, à natureza das concepções que a sua formação anterior e experiência de vida determinam, bem como àquelas outras que traduzem a especificidade dos contextos sócio-culturais nos quais essa formação e experiência ocorreram. [...] Estamos, assim, no interior do paradigma reflexivo na formação de professores e/ou de outros profissionais que, indagando essa complexa relação em espelho, procura compreender, na sua máxima complexidade, como é que a autoimagem se constrói no cruzamento das múltiplas imagens devolvidas, enquanto projeções pessoais no olhar de outros.

A seguir a narrativa que caracteriza o descrito acima:

No dia em que ministrei a aula, havia outras licenciandas na sala, devido a falta de disponibilidade de aulas dos 
docentes. Isso acabou me deixando muito nervosa, e acabou influenciando no meu desempenho, porque eu já não tenho facilidade para falar na frente da sala, com duas licenciandas para avaliar fiquei muito nervosa, falei um pouco rápido, acabei esquecendo de falar algumas coisas que já tinha planejado e a parte da avaliação, também porque restava pouco tempo. (P5)

As narrativas neste nível também evidenciam a percepção sobre a importância da reflexão, levando além da percepção de dificuldades e estratégias para sua superação, à identificação com a profissão:

Após adquirir um maior embasamento teórico e vivência como docente referente à matéria de Metodologia $I$, acredito que evoluí bastante neste atual semestre, tive a oportunidade de organizar melhor o conteúdo da aula ministrada, realizar mudanças na estrutura e design da aula, pude refletir mais sobre as estratégias de ensino sempre tendo como principal objetivo facilitar a construção do conhecimento dos alunos. Nesta aula não fiquei tão nervosa, me senti bastante confortável com os alunos e a docente responsável, me expressei melhor e acredito que transmiti melhor o conhecimento. Ministrar esta aula foi uma experiência importante para o meu crescimento profissional, reconheço que existem pontos a serem modificados porém agora consigo me identificar mais com a docência, sei que consigo ministrar uma boa aula para meus alunos. (P19)

Os estágios colocam o licenciando diante de problemas, de situações reais e é intervindo nestas situações que ele pode ter a oportunidade de refletir sobre os caminhos tomados e sobre seu desempenho. Para Madeira e Lima (2008, p. 452), diante de dilemas, são acionados aspectos tais como: "as crenças do professor, a história dos sujeitos implicados, a percepção da situação, os objetivos, as alternativas de ação disponíveis e as estratégias de resolução." Para as autoras

São transformações dessa ordem que põem em questão os pressupostos da racionalidade técnica no modelo de formação e de atuação dos professores de enfermagem, provocando as necessárias rupturas nesse processo, expressando um movimento que conduz à emergência de concepções alternativas sobre o papel do professor, rupturas que levem ao escapamento do modelo do professor como técnico, postulando sua consolidação como prático reflexivo. 


\subsection{ATIVIDADE "DESCRIÇÃO REFLEXIVA DA SUPERVISÃO EM CAMPO DE PRÁTICA"}

No hospital e/ou na Unidade Básica de Saúde (UBS) o licenciando acompanha o auxiliar e o técnico em enfermagem na realização de atividades práticas que levarão estes profissionais a desenvolverem as competências essenciais para a profissão.

Esta atividade solicitava um relato sobre a experiência no campo de prática (hospital ou UBS) apontando as facilidades e dificuldades encontradas no acompanhamento e avaliação dos estudantes e uma descrição do relacionamento interpessoal envolvendo estudantes, professores supervisores, funcionários e pacientes das instituições onde foram realizados os estágios como vemos na Figura 7.

Figura 7: Atividade - Descrição reflexiva da supervisão em campo de prática

\section{DESCRIÇÃO REFLEXIVA DA SUPERVISÃO EM CAMPO DE PRÁTICA}

Relate sua experiência como licenciando/supervisor de estágio, no hospital e/ou UBS - campo de prática, pontuando as facilidades e dificuldades encontradas no acompanhamento e avaliação dos alunos. .

Descreva seu relacionamento interpessoal com alunos e professores da escola - campo de estágio e com os funcionários, pacientes e familiares do hospital e/ou UBS - campo de estágio.

Autor: Débora Rodrigues Vaz

Nesta atividade todos os portfólios apresentaram narrativas em nível técnico, 21 em nível crítico e 16 em nível metacrítico, como representado no gráfico 2 . 
Gráfico 2: Níveis de reflexão - Atividade "Descrição reflexiva da supervisão em campo de prática".

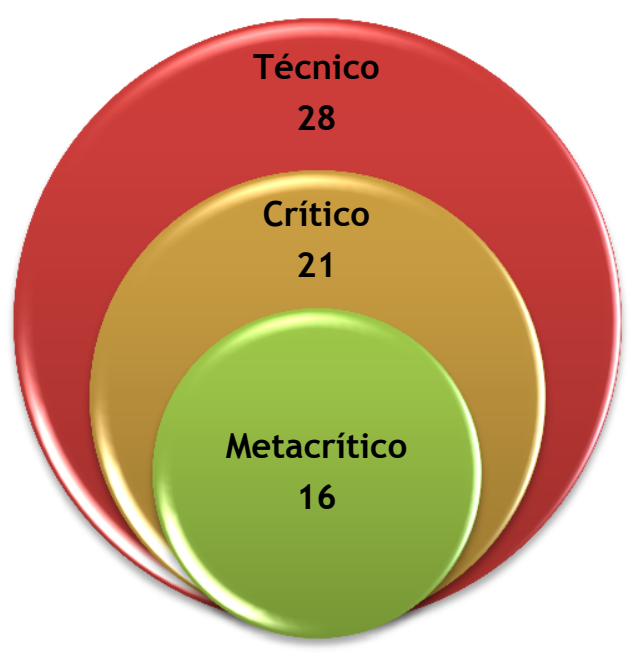

Autor: Débora Rodrigues Vaz

\subsubsection{As narrativas em nível técnico}

A maioria dos portfólios inicia esta atividade situando seu estágio no tempo e no espaço e contextualizando a instituição, caracterizando o nível técnico de reflexão, como nas narrativas descritivas a seguir:

Meu estágio de supervisão em campo de prática ocorreu no Centro Cirúrgico e CME no período de 02 a 08/09. Acompanhei os grupos de alunos que estão cursando a matéria de Clínica Médica. (P19)

Esse campo é formado por 20 leitos de pacientes que necessitam de cuidados intensivos (monitorização hemodinâmica, drogas vasoativas por bomba de infusão contínua e observação rigorosa) devido à gravidade do quadro clínico. Há apenas 2 enfermeiras por turno e 7 auxiliares, não há técnicos de enfermagem nesse campo, apesar de todos os auxiliares serem técnicos ou já graduados em enfermagem. (P3)

Após situarem-se, os licenciandos passaram a apresentar narrativas descritivas sobre as facilidades e dificuldades encontradas no acompanhamento dos estudantes e como se deu o relacionamento entre estudantes, professores supervisores, funcionários do campo de estágio e pacientes. 
Nas narrativas em nível técnico a seguir, os licenciandos destacaram que suas experiências anteriores influenciaram no acompanhamento dos estudantes:

[...] algumas dificuldades surgiram, embora eu já tivesse passado pelo hospital, não tenho muito conhecimento de

UTI, o que consumiu algum tempo até me adaptar para poder ajudar os alunos. [...] A falta de experiência prática

em hospital, embora não tenha sido fundamental, bem como os alunos e a professora terem compreendido essa limitação pessoal, achei que esse foi um dos mais dificultadores do estágio. (P14)

Apesar de o estágio ser sobre administração, foi realizado na enfermaria de transplante de fígado e ao ver os pacientes ou seus prontuários, os alunos traziam questões relacionadas a esse tema, que eu não domino, porém procurei me informar a respeito (P15)

Outro fator relatado no acompanhamento dos estudantes foi conhecê-los previamente:

Como já havia dado as aulas para aquele grupo de alunos, estes acabavam reportando-se a mim, em casos de dúvidas ou para discussão de problemáticas levantadas na unidade. (P17)

Meu relacionamento interpessoal com os alunos e a docente responsável pelo estágio foi muito bom, eu já conhecia os alunos devido ao estágio anterior na escola de enfermagem, logo me senti muito a vontade $e$ confortável com eles, todos me acolheram muito bem, me respeitavam e me auxiliaram no desempenho como monitora de estágio. (P19)

As narrativas descreveram que a motivação dos estudantes em aprender e participar das atividades propostas pelo estágio também influenciaram no acompanhamento dos estudantes:

As facilidade foram a disposição e interesse dos alunos, a maneira da professora supervisionar, atenciosa $e$ motivadora em relação a pesquisa e ao pensamento crítico-reflexivo dos alunos (P2)

Como dificuldade posso citar a falta de vontade das alunas em se inserirem nas atividades do setor, eu questionei se elas não queriam auxiliar os técnicos na embalagem dos materiais, as alunas não viam importância nisso e não quiseram realizar. Como o setor é pequeno não tinha muita coisa para fazer, logo as alunas ficavam impacientes, reclamavam que o tempo não passava. (P19) 
As características dos campos de estágio foram destacadas nas narrativas a seguir:

No geral, a unidade possui uma boa estrutura para os pacientes, porém, em relação ao aprendizado dos estagiários o espaço físico não é adequado para discussão de casos. O posto de enfermagem e a sala de medicação são pequenos e estão sempre cheios de pessoas. Às vezes, as atividades eram realizadas na sala que dá acesso à varanda ou mesmo no corredor da unidade. Ambos os espaços atrapalhavam a passagem de profissionais e pacientes. (P10)

Como dito anteriormente, o fator que mais dificultou o desenvolvimento do estágio foi a estrutura física da unidade. Além disso, a receptibilidade de alguns profissionais foi uma barreira para mim e para a professora que acompanhava a turma. (P10)

O relacionamento com estudantes, professores supervisores, colaboradores e pacientes das instituições de saúde também foram descritos como fatores que influenciaram o acompanhamento do estágio. As narrativas a seguir descreveram como foi 0 relacionamento com os estudantes:

Com os alunos tentei estabelecer uma relação de confiança demonstrando que estava ali para auxiliá-los em seu aprendizado. Minha conduta tinha por objetivo abrir espaço para que pudessem desempenhar aquilo que aprenderam em sala de aula e, ao mesmo tempo, atuava de modo a resguardar a segurança deles e dos pacientes (ex. preparo e administração de medicamentos). Tentava, também, não lhes dar a sensação de que estava ali para vigiá-los ou apontar o que estavam fazendo de errado, mas sim para auxiliar o desempenho correto das técnicas propostas e lhes dar apoio durante a realização de algum procedimento. (P1)

Os alunos, principalmente, demonstraram a correta compreensão acerca da minha presença no decorrer do estágio deles e colaboraram com minha formação como professora. (P18)

As facilidades encontradas foram o bom relacionamento entre os próprios alunos e a boa receptividade que tive dos alunos, da professora e dos funcionários. (P24)

As narrativas descreveram a percepção dos licenciandos em relação às dificuldades apresentadas pelos estudantes. Para Alarcão (2010, p. 68) 
se o aluno é o elemento central da ação educativa, é imprescindível que o professor detenha conhecimento do aluno e das suas características, isto é, compreenda o seu passado e o seu presente, a sua história de aprendizagem, o seu nível de desenvolvimento, a sua envolvente sociocultural.

A seguir narrativas em nível técnico que destacam estas percepções:

Consegui perceber dificuldades em alguns alunos e outros que tinham um bom domínio da matéria e dos procedimentos. Porém, algo que todos tinham em comum era a falta de raciocínio clínico, ou seja, de juntar tudo o que tinham aprendido em um só paciente. Além disso, suas anotações de enfermagem eram fracas devido a ausência de domínio das terminologias corretas. (P10)

Uma dificuldade encontrada é a pontualidade dos alunos, já que como saem do trabalho as $13 \mathrm{~h}$ chegam no estágio sempre de 30 a 60 minutos atrasados, além disso chegam bastante cansados, vemos que possuem um potencial muito grande, mas o cansaço contribui para que tenham um desempenho inferior ao esperado. (P13)

Todos os alunos em estágio demonstraram segurança, interesse e iniciativa em desempenhar as técnicas propostas, no entanto, a maior dificuldade apresentada por eles foi as anotações de enfermagem, eles possuem muitas dificuldades gramaticais $e$ insegurança para escrever. (P23)

As narrativas também descreveram como foi o relacionamento com os professores supervisores. Para Simões e Garrido (2007, p. 600)

Hoje, não podemos conceber a supervisão dos estudantes apenas numa estreita relação de ajuda, se ela não incluir em si mesma a noção de contínuo, reflexão e retroalimentação numa perspectiva de desenvolvimento pessoal e profissional do estudante. Será, portanto, essencial que os supervisores de estágio dominem conhecimentos na área da supervisão.

A seguir as descrições deste relacionamento:

Meu relacionamento com a professora também se estabeleceu de maneira bastante saudável, ela me orientava quanto à supervisão dos alunos, facilidades e dificuldades encontradas no cotidiano do trabalho do enfermeiro, em relação ao futuro profissional e outros assuntos. (P2)

Meu relacionamento com a docente do campo de estágio foi maravilhoso, já havia trabalhado com ela anteriormente, já havíamos construído uma relação de 
confiança que foi consolidada com este estágio atual. $A$ docente é o meu exemplo de como uma docente pode ser rigorosa com os alunos, mas ao mesmo tempo acolhê-los, compreendê-los, e principalmente ser amiga dos alunos. A docente sempre me deixou a vontade, me ensinou muitos procedimentos e equipamentos no Centro Cirúrgico, e acima de tudo me ensinou como ser uma boa docente para meus alunos, como explorar meus conhecimentos para crescer profissionalmente. Agradeço a ela pela oportunidade de estagiar no seu campo, poder ser sua amiga e evoluir como futura docente. (P19)

Já com a professora da Escola de Enfermagem tive algumas dificuldades de relacionamento e creio que estas devem ser expostas, já que mais alunos poderão estar com ela em estágio nas próximas disciplinas. [...]

Desde início do estágio não percebi flexibilidade e disponibilidade da professora para comigo e principalmente para com os alunos. Vários foram os momentos em que ela demonstrou falta de paciência e tolerância com dúvidas e dificuldades expostas, respondendo rispidamente ao que lhe foi indagado. (P18)

Para Alarcão (2010, p. 71) a "supervisão é uma atividade de natureza psicossocial, de construção intra e interpessoal, fortemente enraizada no conhecimento do eu, do outro e dos contextos em que os atores interagem", especificamente nos contextos formativos. Deve basear-se na "interação entre o pensamento e a ação, com o objetivo de dar sentido ao vivido e ao conhecido, isto é, de compreender melhor para melhor agir" e deve propiciar "o desenvolvimento de capacidades, atitudes e conhecimentos e o contributo destes para a competência profissional, essa de natureza integrada e holística".

Para Pimenta (2012, p. 65)

Um curso de formação estará dando conta do aspecto prático da profissão na medida em que possibilite o treinamento, em situações experimentais, de determinadas habilidades consideradas a priori como necessárias ao bom desempenho do docente.

Muitas narrativas descreveram as atividades realizadas pelos licenciandos e a autonomia proporcionada pelos professores supervisores:

Pude acompanhar de perto os alunos, debater o roteiro, auxiliar nas dúvidas, identificar os pontos que precisam ser melhorados e direcionar os 
estudos dos alunos. (P19)

\begin{abstract}
Ainda assim, a professora me deixou muito a vontade para fazer o que eu achasse melhor com os alunos e isso também ajudou muito. Então dividimos o aluno em dois grupos para dois pacientes. A docente ficou responsável pelo paciente mais grave e eu fiquei com os alunos junto com uma paciente que estava mais estável e com menos procedimentos para realizar. (P14)
\end{abstract}

Algumas vezes (nome da professora) ficava comigo e com os alunos e depois nos últimos dias, ela começou a me deixar com eles sob minha responsabilidade, principalmente na sala de procedimentos, que era o local onde eles tinham mais dúvidas e necessitava de maior supervisão. (P25)

As narrativas também descreveram como foi o relacionamento com os colaboradores das instituições de saúde, suas dificuldades e facilidades. Stutz e Jansen (2006, p. 220), em pesquisa sobre experiências vivenciadas por estudantes no estágio curricular do curso técnico em enfermagem, afirmam que a participação dos professores e funcionários têm importante papel na redução da ansiedade, fortalecimento da autoconfiança e autoestima dos estudantes, auxiliando estes a enfrentarem os desafios que representam a aprendizagem prática da enfermagem nos contatos iniciais com o mundo do trabalho. Os autores, na pesquisa citada, constataram uma dificuldade acentuada dos estudantes em fase inicial do processo de aprendizagem prática, com os funcionários junto aos quais atuam diretamente na instituição hospitalar, durante a realização dos cuidados aos pacientes, dificuldades estas que variaram desde a instabilidade de humor e resistência dos funcionários a orientar professores e estudantes, indiferença por parte de alguns funcionários, até recusa em acompanhar o estagiário. Narrativas em nível técnico descreveram situações que exemplificam estes fatos:

Os profissionais que atuam no campo foram receptivos e atenciosos quanto às dúvidas e questionamentos. $O$ ambiente possui estrutura física adequada, recursos humanos em quantidade adequada para a demanda, $o$ que permite os profissionais disponibilizarem tempo para orientar os alunos, também possuem bom relacionamento entre eles, e há disponibilidade de recursos materiais. $(P 2)$ 
A equipe de enfermagem nos recebeu super bem, sem nenhuma resistência quanto à nossa presença $e$ colaborou com o aprendizado dos alunos disponibilizando materiais, impressos, escalas, etc. para que eles pudessem manipular e perceber como tudo acontece na prática. (P15)

Outro ponto importante foi a falta de vontade das enfermeiras do setor para conversarem com as alunas, quando nós íamos perguntar se elas poderiam esclarecer alguns pontos sempre ouvíamos a resposta que elas estavam muito ocupadas agora e se elas não poderiam conversar em outro momento, porem nunca havia tempo para a conversa. (P19)

\section{As narrativas também descreveram o relacionamento com os} pacientes e familiares nas instituições de saúde:

Quanto aos familiares, mostraram satisfação de verem que a mãe estava sendo cuidada por alunos $e$ professores, pois sentiam que ela estava bem assistida o tempo todo. Conversamos bastante com os filhos, bem como falávamos o tempo todo com a paciente. Mesmo que esta não respondesse verbalmente, os alunos não deixavam de explicar o procedimento, pedir licença e elogiar a força e a presença constante de todos os filhos no hospital, revezando sempre que podiam. (P14)

Sendo uma unidade de cuidados intensivos, a maioria dos pacientes permanecia sedado, sendo alguns deles entubados. Mesmo assim, ensinava aos alunos que devíamos conversar com os pacientes antes de realizar qualquer procedimento, pois do contrário, não aparentava que estávamos cuidando de pessoas e sim de objetos. Sempre mostrava a eles a importância da comunicação no contexto hospitalar. (P16)

\section{Quanto ao processo de avaliação, aspecto solicitado na atividade,} houve poucas narrativas em nível técnico:

No último dia, foi a avaliação do estágio dos alunos na Escola. Eles entregaram a autoavaliação que haviam feito e a professora os chamou individualmente, mencionando os pontos positivos e os negativos de cada aluno, enfatizando o que poderia ser melhorado. Ela Ihes entregava a auto-avaliação que eles fizeram junto com a

avaliação dela, para que eles pudessem comparar as

notas (apenas uma aluna se auto-avaliou dando uma nota inferior à da professora). Depois disso, ela me perguntava se eu queria fazer algum comentário e, assim como ela, eu mencionava os pontos positivos e negativos deles em estágio. Ao final, quando ficamos eu e a (nome da professora) na sala, ela entregou a minha auto-avaliação com a nota dela sobre meu estágio.

Recebi uma nota maior do que a que me dei. Ela disse que admirou minha postura, que sou uma ótima 
professora e ótima enfermeira. Foi gratificante ouvir isso ao final dos dois cursos; todo o meu esforço foi, mais uma vez, reconhecido. (P4)

A avaliação usada em estágio foi com base em um instrumento oferecido pelo próprio (nome da escola) que inclui itens como: pontualidade, assiduidade, participação das atividades, relacionamento interpessoal, conhecimento técnico-científico, não constando a autoavaliação. Porém nesse dia foi realizada um conversa informal entre os alunos e professor e licencianda, que disseram algumas características de cada aluno e como ele contribui para o estágio. (P7)

Por ser um estágio de apenas cinco dias, pude participar da avaliação parcial das alunas, entretanto esta ocorre durante todo o processo, de forma contínua e global, abrangendo conhecimentos, habilidades e atitudes, mediante observação do comportamento dos alunos e da análise do registro da ficha de acompanhamento. (P8)

Narrativas em nível técnico também descreveram sentimentos relacionados às experiências vividas, algumas com potencialidade para os níveis crítico e metacrítico.

Nas narrativas a seguir, os licenciandos conseguiram perceber sua evolução em relação ao estágio, porém não explicitaram os motivos que os levaram a tais percepções, o que confere a estas narrativas características meramente descritivas:

Minha experiência como licencianda/supervisora de estágio foi muito mais completa neste semestre. Pude participar do estágio dos alunos da Escola de Enfermagem do início ao fim e ver a evolução dos alunos, do docente e minha. (P12)

Acompanhei estágio com um grupo de alunos de auxiliares de enfermagem, em uma das clínicas médicas durante 7 dias. Minha experiência de supervisão de estágio foi bastante positiva, melhor do que minha experiência anterior na disciplina de metodologia I, pois pude acompanhar melhor a formação dos alunos neste campo de estágio. O primeiro dia foi de reconhecimento de campo, mas nos demais dias eu e a professora da turma nos dividíamos: enquanto ela assumia junto com alguns deles as medicações, eu ficava responsável pela orientação nos cuidados de enfermagem dispensados pelos outros alunos, assim, minha imagem dentro do grupo era realmente de docente. (P6) 


\subsubsection{As narrativas em nível crítico}

Neste nível de reflexão, segundo Sá-Chaves (2000) o licenciando identifica as múltiplas e possíveis causas, consequências e significados dos fatos narrados, o papel dos contextos na determinação dos fatos, os papéis desempenhados e as concepções que os sustentam e ainda sobre os novos papéis que podem vir a ser desempenhados.

Para Barreiro e Gebran (2006, p. 21)

A formação inicial e o estágio devem pautar-se pela investigação da realidade, por uma prática intencional, de modo que as ações sejam marcadas por processos reflexivos entre professores-formadores e os futuros professores, ao examinarem, questionarem e avaliarem criticamente o seu fazer, o seu pensar e a sua prática.

Nas narrativas os licenciandos refletiram sobre a influência das experiências anteriores no acompanhamento do estudante durante 0 estágio, como em P9, que apresentou narrativas que vão além da descrição. Na primeira narrativa evidenciou a percepção de que determinado fato, a aula sobre simulação, faria diferença no seu desempenho no estágio e a segunda narrativa, demonstrou que o licenciando percebeu a importância da teoria para o estágio:

Infelizmente realizei o estágio antes de ter a aula sobre simulação no ensino técnico em enfermagem, essa aula teria sido de grande valia na elucidação de como devemos demonstrar um procedimento ao aluno. (P9)

Todas as aulas que tive durante a licenciatura entram como facilitadores nessa atividade, pois percebi o quanto evolui no auxílio ao aluno, na forma com que auxiliei os alunos a promover o aprendizado. Compreender o processo de ensino-aprendizagem e as estratégias de ensino também foram essenciais. [...] Minha experiência de estágios na graduação, como estudante de enfermagem, foram essenciais nas orientações aos alunos. Sinto que tudo o que aprendi é de grande importância na hora em que os alunos trazem as dúvidas. (P9) 
A seguir outras narrativas em nível crítico que falam da influência de experiências anteriores:

Percebi a importância da experiência prática na área da enfermagem e o quanto isso ajuda um docente no campo. Na sala de aula, um professor sem experiência pode ser um bom docente independente do quanto é sua experiência prática, mas acho muito difícil para um professor não ter essa vivência quando está com os alunos em campo de estágio (P14)

Penso que houve somente um aspecto dificultador que foi a minha curta experiência em centro cirúrgico, o que resultou em uma limitada colaboração para as alunas (P8)

Como observado nas narrativas em nível crítico, o conhecimento prévio do campo de estágio, dos estudantes e do professor supervisor também foi evidenciado como fator que pode influenciar no desempenho do licenciando. A seguir P6 fala sobre a diferença que faria conhecer antecipadamente o campo e P5 explica o porquê sentiu dificuldade de relacionamento com a primeira turma, o que confere a estas narrativas uma relação de causa e consequência, característica do nível crítico:

Quanto aspectos dificultadores, destaco o conhecimento da rotina da clínica junto com os alunos, acho que tanto eu (enquanto licencianda) quanto os alunos teríamos melhor aproveitamento do estágio se houvesse um conhecimento anterior da rotina da clínica pelo professor da turma. (P6)

Analisando o relacionamento interpessoal com o professor e com os funcionários, acredito que tenha sido ótimo, obviamente que tendo acompanhado estágio no mesmo lugar com o mesmo professor no mesmo lugar anteriormente tenha contribuído muito para isso. Senti um pouco de dificuldade de relacionamento com a primeira turma no primeiro dia, mas atribuo isso ao fato de eles estarem terminando o estágio quando eu comecei e tive um pouco de dificuldade para me adaptar, já que anteriormente coincidiu de o meu primeiro dia ser também o primeiro dia dos alunos. (P5)

Narrativas reflexivas em nível crítico demonstraram uma percepção das facilidades e dificuldades no acompanhamento dos estudantes em relação a sua quantidade e a responsabilidade atribuída ao professor: 
As dificuldades foram muitas durante a semana. Acredito que a maior dificuldade foi dar atenção à todos os

alunos. Talvez por serem a turma de auxiliar, e terem pouca experiência em ambiente hospitalar, eles requerem atenção dobrada e a todo o tempo do estágio. Portanto, cometem muitos erros e temos que ficar atentos à segurança do paciente. (P9)

Uma facilidade importante é que os grupos são pequenos (7 alunos), contribuindo para que pudéssemos dar atenção individualizada a todos, tirando dúvidas e acompanhando as atividades. Além disso, a maioria dos alunos já trabalha na área como auxiliar de

enfermagem, trazendo não só embasamento teórico como prático, além claro, da troca de experiências entre os alunos. (P13)

Dentre as dificuldades, podemos citar o grande número de alunos, o que exige muito do professor, pois na verdade ele fica responsável por 10 alunos e 10 pacientes, um menor número de alunos permitiria um maior acompanhamento por parte do professor. (P23)

Como solicitava a atividade, o relacionamento interpessoal foi apresentado em muitas narrativas em nível crítico.

Para Alarcão (2001) a supervisão é entendida como uma atividade mediadora nos processos de aprendizagem e de desenvolvimento do formando e do supervisor, podendo ser facilitada ou inibida, de acordo com a natureza da relação estabelecida. Para que cada um seja estimulado a progredir e criar seu estilo próprio de intervenção é fundamental que as interações se desenvolvam num ambiente de confiança e interajuda afetiva e cognitivamente estimulante (pois a autora acredita que o supervisor também está em desenvolvimento). As narrativas a seguir, vão além da descrição, especificando os motivos pelos quais o relacionamento com o professor supervisor facilitou o estágio:

O que facilitou muito o acompanhamento do estágio foi o fato de já conhecer a docente, do estágio anterior; termos tido boa comunicação antes, durante e depois do estágio, bem como ter tido um bom relacionamento com os alunos $(P 14)$

As principais facilidades que encontrei foram o fato da docente que acompanhava o estágio estabelecer um vínculo de confiança comigo e me tratar como uma futura docente, me possibilitando a oportunidade de realmente acompanhar os alunos em procedimentos e na 
elucidação de suas dúvidas, e não somente observar a sua atuação como docente. (P1)

As facilidades que encontrei no acompanhamento foram:

o apoio da professora que estava acompanhando o estágio com os alunos pois todo o momento ela perguntava se eu queria acrescentar alguma coisa ao estágio, alguma experiência ou uma nota acerca de um dado assunto e me permitia auxiliar os alunos nos procedimentos, confiando na minha capacidade. (P21)

Nas narrativas em nível crítico a seguir, o relacionamento com os estudantes também foi considerado fator facilitador para o estágio:

Outro fator facilitador foi a receptividade e aceitação dos alunos que permitiam e solicitavam meu auxilio na execução de procedimentos e a conduta positiva dos funcionários da unidade, que nos chamavam para realizar e observar procedimentos e ajudavam a solucionar possíveis dúvidas com relação à unidade. (P1)

Quanto aos facilitadores aponto [...]a ótima interação dos alunos comigo durante todo o período, confiando em minha orientação e solicitando minha supervisão; a orientação e estímulo da professora de estágio quanto ao que eu devo melhorar. (P18)

Algumas narrativas em nível crítico evidenciaram a percepção dos licenciandos em relação ao relacionamento professor supervisor e estudantes:

Pelo fato das alunas mostrarem-se bastante interessadas não senti problemas na forma com que o estágio aconteceu, porém percebi que de acordo com o docente que acompanha os estágios, os alunos têm a chance de desenvolver e agregar conhecimentos diferenciados. (P17)

A necessidade da formação de um vínculo entre professor e aluno é indispensável para o interesse no aprendizado do aluno. Percebi nesse caso o quanto o professor foi aberto para dúvidas, sugestões e criticas. (P24)

A narrativa de P18 apresentou nível crítico com potencial para o nível metacrítico, pois além de perceber a problemática na relação do professor supervisor com os estudantes, inicia uma reflexão sobre o seu papel, como se percebeu na situação descrita:

Quanto aos aspectos que dificultaram meu desempenho com o acompanhamento e avaliação dos alunos vale destacar a falta de entrosamento entre os alunos e a professora do estágio, evidenciando uma relação de 
subordinação dos alunos a professora; a falta de comunicação entre a professora e os alunos; a necessidade de ser a ligação, a ponte entre eles em algumas situações e perceber-me sozinha com os alunos em dados momentos e não saber que conduta tomar diante de dúvidas e anseios expostos por eles. (P18)

Algumas narrativas em nível crítico demonstraram o reconhecimento, por parte dos licenciandos, da importância do estágio para os estudantes e para si mesmo. A seguir P15 consegue perceber a potencialidade do estágio, um contexto diferente da sala de aula, caracterizando o nível crítico:

O campo de estágio é um lugar muito bom para se estar ao lado do aluno. Ao contrário do que acontece na sala de aula, onde muitas vezes os alunos não participam da construção do seu conhecimento, no estágio eles são a parte mais ativa do aprendizado. Para mim foi uma experiência muito rica, e acredito que não poderia ter sido melhor. (P15)

Algumas narrativas em nível crítico evidenciaram a complexidade do relacionamento interpessoal no estágio em instituições de saúde:

Quando estamos como professores somos o link entre os profissionais e os alunos. Muitos alunos passam por um mesmo campo de estágio, mas os professores continuam, sendo essencial que haja uma boa relação entre os professores e os profissionais da unidade. (P13)

Percebi o quanto é desafiador para um docente ensinar no campo prático, quando a família, o paciente e os funcionários têm diversas expectativas no aluno e fica mais difícil ainda quando o professor conhece pouco dos alunos. (P14)

Sobre o processo de avaliação, as narrativas em nível crítico demonstraram uma reflexão mais aprofundada sobre a atribuição de conceitos e imparcialidade. Apresentaram análise do acontecimento a partir de uma visão ética da avaliação, do respeito, como evidenciam as narrativas a seguir:

Encontrando [...] os seguintes fatores facilitadores como: a criação de um vínculo entre os alunos durante os sete dias de estágio, o reconhecimento de cada um com suas limitações e superações. Porém a dificuldade se apresentou em: colocar notas para cada aluno no que se refere a participação, pois algumas alunas por timidez não se expressavam no momento da discussão em grupo mas conseguiam articular os conteúdos quando estavam em grupo menores.(P7) 
Em minha opinião, ainda sem muita experiência, essa é uma das tarefas mais difíceis do professor... deixar a empatia de lado e tratar todos os alunos da mesma forma e com ética. Não só durante a aula e em estágios, mas principalmente durante a avaliação, por isso, a extrema importância do professor ter com ele mesmo e com os alunos, critérios bem definidos de avaliação, com o intuito de deixar isso de forma mais técnica e menos pessoal. (P13)

Narrativas em nível crítico também demonstraram a oportunidade da experiência do "ser docente", vivenciada por alguns licenciandos. A seguir algumas narrativas com potencial para o nível metacrítico, pois além de refletirem sobre as vivências perceberam o que essa vivência pode trazer para o próprio desempenho no futuro:

O relacionamento com a docente do campo de estágio foi muito enriquecedora, embora tenha apontado como dificuldade o fato de ficar a maior parte do tempo afastada dos alunos durante o estágio, foi também uma oportunidade para poder discutir diversos aspectos do ser docente com a Professora. Acredito ter ganhado muito neste aspecto, especialmente pelo fato de ela ter uma vasta experiência na área, ela se empenhou em me apresentar todas as facilidades, dificuldades que enfrentou na profissão de docente do ensino técnico de enfermagem, foi realmente algo muito enriquecedor na minha prática profissional, foram ensinamentos que com certeza irão me auxiliar neste início na carreira de docente. (P11)

Este estágio para mim foi um divisor de águas, no qual tive a oportunidade de realmente vivenciar a prática docente. Era considerada como professora tanto pelas alunas quanto pelos funcionários da unidade e poder relacionar-me com docente foi muito enriquecedor e confirmou minha vontade em seguir nesta área. (P12)

\subsubsection{As narrativas em nível metacrítico}

Neste nível as narrativas evidenciam reflexões sobre si próprio, seus papéis, desempenhos e concepções, tornando-se ator e objeto da própria reflexão (Sá-Chaves).

Narrativas em nível metacrítico, envolvendo o reconhecimento do próprio desempenho, também relacionaram o fato da experiência anterior, tanto na docência como na enfermagem. As narrativas a 
seguir têm o "eu" como foco, apresentaram reflexões sobre o próprio desempenho e o papel que estavam desempenhando:

As minhas dificuldades estiveram relacionadas à supervisão de tarefas técnicas que não tenho habilidade. Acredito que se eu tivesse mais experiência teóricoprática minha supervisão teria sido melhor aplicada.

Mesmo assim, considero que consegui atingir os objetivos do estágio, pois busquei informações, estudei e retribui o conhecimento para os alunos. (P3)

Nesse caso a licencianda, por ser aprimoranda em Hospital particular de referência em transplante de fígado conseguia responder e refletir junto a eles sobre essas questões, mas muitos aspectos ficaram em "aberto" que fizeram a aluna buscar materiais e estudar sobre o assunto relacionado ao perfil dos pacientes da unidade. (P7)

Senti um pouco de dificuldade na parte técnica, pois, não tenho muita vivência prática apesar de estar formada e ter trabalhado na Estratégia da Saúde da Família, fazia um tempo que não fazia alguns procedimentos então precisei revisar técnicas e treinar antes de ir para o estágio. (P12)

Quando a professora me passou com quais pacientes e alunos seria responsável fiquei meio estranho! Uma sensação de responsabilidade, muito maior da qual havia sentido nos estágios curriculares. Percebi que era o responsável pelo paciente e pelos alunos e não poderia vacilar em hipótese alguma. (P16)

Nas narrativas em nível metacrítico os licenciandos refletiram sobre o relacionamento interpessoal entre eles e os outros atores envolvidos no estágio.

As facilidades que encontrei foram as de comunicação e relacionamento entre o grupo. Acredito que consegui interagir, me envolver e me comunicar efetivamente com os alunos e docente, promovendo uma melhor compreensão do conteúdo e objetivos do estágio, levando os alunos a uma orientação e acompanhamento mais eficaz. $(P 3)$

Consegui desenvolver um relacionamento de confiança e compromisso com o campo e funcionários, pois consegui reconhecer suas dificuldades e facilidades e deixei minhas fragilidades e capacidades expostas a eles para que estes se sentissem confortáveis em se relacionar com o grupo todo. (P3)

Já com os pacientes e familiares não pude interagir muito, pois a maioria dos pacientes estava confuso, intubado ou sedado, o que impossibilitou a comunicação verbal. Apesar disso, consegui estabelecer afeto e cuidado e transmiti esses sentimentos ao grupo 
A avaliação foi contemplada nas narrativas em nível metacrítico, como em P15, que refletiu sobre o seu desempenho durante a avaliação dos estudantes:

Avaliar os alunos foi uma tarefa muito difícil para mim, principalmente por se tratar do componente prático, onde tudo é muito dinâmico e avaliação acaba se tornando mais subjetiva. Ao avaliá-los fiquei em dúvida se estava sendo justa ou não. Como aluna, eu sempre detestei fazer auto-avaliação (P15)

Algumas narrativas salientaram a percepção do significado do estágio na futura prática pedagógica, da necessidade da mudança, do aprimoramento:

Considero que a realização deste estágio me ajudou a ter mais segurança para atuar como docente, apesar de saber que ainda preciso me aprimorar em diversos pontos, como timidez e dificuldade em falar em público. Mas esta com certeza foi uma experiência válida e que acrescentou muito em meu aprendizado. (P1)

Além disso, acredito que ter me focado nos objetivos do estágio ajudou a esclarecer a mim e aos alunos, meu papel no campo e o comprometimento em aprender para poder ensinar. (P14)

Antes de tudo gostaria de ressaltar que mais do que os pontos positivos registrados acima, relativos a questão relacionamento interpessoal, os negativos que informarei a seguir possibilitaram maior aprendizado em mim como licencianda e como pessoa, uma vez que provocaram autorreflexão acerca da professora que almejo ser e do ser humano que sou. (P18)

Neste estágio realmente consegui atingir meus objetivos como supervisora de estágio, acredito que contribui para a formação dos alunos e cresci muito como futura docente. (P19)

Os resultados mostraram que nas duas atividades analisadas, todos os portfólios apresentaram narrativas em nível técnico, mas nem todos atingiram o nível crítico e/ou metacrítico, o que pode ter sido influenciado por vários fatores.

$\mathrm{Na}$ perspectiva da formação de professores, um portfólio reflexivo pode caracterizar-se como uma "descrição baseada nas realizações de ensino do professor e apoiada em dados relevantes que, depois 
de analisados pelo próprio, evidenciem o processo de pensamento por detrás dos instrumentos concebidos, construídos e implementados" (Moreira, 2010, p. 30). Dessa forma, deseja-se que o portfólio se constitua como amostra selecionada e ilustrativa do modo como esse professor desenvolveu sua prática pedagógica nos espaços onde ocorreram suas atividades.

A Rota de Aprendizagem tem a função de orientar o licenciando na elaboração do portfólio, estimulando-o a refletir sobre a prática pedagogia vivenciada e levando-o a níveis de reflexão além do descritivo, assim suas atividades devem possuir características que alcancem tais objetivos.

Apesar das atividades solicitarem "descrições reflexivas", seus desdobramentos utilizaram na maioria das vezes verbos como "descreva" e "relate", que aparentemente estimulam mais a descrição. Tal fato pode ter influenciado o nível de reflexão alcançado pelos licenciandos, mas sua certificação exige um estudo cuidadoso e aprofundado.

Para Smyth (1989 apud Amaral, Moreira e Ribeiro, 1996, p. 103) o processo de formação de professores deve passar por quatro tarefas integradas, que vão da "descrição dos eventos educativos à reconstrução de concepções e práticas, passando pela interpretação e confronto de perspectivas". Desta forma, a descrição é necessária, mas é só o início do processo.

Além dos aspectos inerentes a proposta do portfólio, é preciso também levar em consideração outros aspectos que podem interferir nos níveis de reflexão apresentados pelos portfólios.

Grilo e Machado (2005, p. 31), analisando narrativas presentes em portfólios de professores estagiários, chegaram a algumas conclusões que podem aqui também ser consideradas. Os 
estudantes envolvidos no estudo podem não se encontrarem todos no mesmo nível de desenvolvimento reflexivo, uma maior representação de narrativas em nível técnico nos leva a supor que os estudantes envolvidos estão passando por um processo de desenvolvimento reflexivo, iniciando pelo que os autores chamaram de "ponto quase zero de partida" e durante o qual estão se desenvolvendo.

De acordo com os mesmos autores, um professor em formação, pode apresentar capacidades analíticas para a reflexão e desenvolver uma prática coerente com estas capacidades, no entanto não deixar transparecê-las em seu portfólio. Salientam ainda que o portfólio, por si só, não necessariamente levará os professores à reflexão crítica, e como estratégia, não pode fazer mais do que capturar um momento do processo de formação pelo qual os professores estão passando:

Um momento preponderante, fundamental e
estruturante, com um extraordinário potencial de
crescimento e desenvolvimento para o formando,
sustentado numa também potencialmente riquíssima
rede de interações e colaborações sem paralelo noutros
momentos de formação. Mas, ainda assim, apenas um
momento de um longo percurso (Grilo, Machado, 2005,
p. 33).

Para Ramos e Gonçalves (1996, p. 140) outro aspecto a ser considerado é que o "desenvolvimento e o grau de estruturação/seleção de conteúdos das narrativas parecem andar de mãos dadas", uma vez que o "processo de escrita parece refletir (e/ou ser reflexo) do estádio de desenvolvimento pessoal e profissional de quem escreve", e também parece ser capaz de fornecer evidências incontestáveis sobre o próprio processo pelo qual passa o professor no que diz respeito ao seu crescimento profissional.

Ainda para os autores, como todo o processo de prática pedagógica acaba sendo levado em consideração nos momentos de avaliação, pode tornar-se difícil para professores-estagiários retirar toda a 
dimensão avaliativa de suas produções, o que pode influenciar no desenvolvimento de suas narrativas/reflexões.

Alguns portfólios apresentaram narrativas abrangendo somente 0 explicitado na Rota de Aprendizagem proposta, outros foram além, sendo mais detalhistas sobre os aspectos solicitados. As atividades direcionavam para experiências específicas vivenciadas no estágio, assim as narrativas se assemelham quanto aos acontecimentos. Algumas narrativas foram organizadas pelos tópicos solicitados, outras apresentaram um texto único.

De acordo com Ramos e Gonçalves (1996, p. 138)

\begin{abstract}
A progressão e a periodicidade da escrita dependerão das características pessoais de cada um e das razões que o levaram a escrever. Para alguns será frutuoso sentarem-se, ao fim de cada dia de trabalho, e lembrarem os aspectos que mais se salientam: pensamentos, sentimentos, acontecimentos significativos; para outros, será preferível optar pelo registro, ainda que por tópicos, e tão próximo quanto possível do acontecimento em questão, o que tornará mais fácil a sua descrição ou interpretação a posteriori.
\end{abstract}




\section{CONCLUSÕES}

Para Sá-Chaves (2005, p. 13) os portfólios devem ser lidos "com respeito absoluto pelos modos e expressões singulares com que cada eu se manifesta (ou se oculta) para melhor gerir a sua capacidade de ser, de fazer, de entender e de partilhar o mundo".

O portfólio proporcionou o desenvolvimento dos três níveis de reflexão propostos por Sá-Chaves, porém nem todos os licenciandos alcançaram o nível crítico e metacrítico.

Algumas narrativas apresentaram características de transição entre um nível e outro. A decisão sobre em qual nível deveria ser classificada foi tomada levando em consideração as potencialidades das narrativas para determinado nível.

Nas narrativas em nível técnico e crítico os estudantes descreveram e refletiram sobre suas vivências mais significativas em relação aos tópicos solicitados na Rota de Aprendizagem, envolvendo o planejamento e a execução da aula, o processo de avaliação e a relação entre professor supervisor e licenciando tanto nas escolas como nas instituições de saúde.

Os licenciandos tiveram oportunidade de vivenciar a prática pedagógica e muitos apresentaram reflexões em nível metacrítico, refletindo sobre seu desempenho, sobre a construção da identidade docente e sobre a importância de refletir sobre a prática com o objetivo de transformá-la e transformar-se a si mesmo.

Refletir sobre seu desempenho não é tarefa fácil e o portfólio guiado pela Rota de Aprendizagem proporcionou a alguns licenciandos a oportunidade de desenvolver este nível de reflexão. Eles foram capazes de perceber suas dificuldades e propor melhorias. 
Além dos fatores pessoais que influenciam a capacidade de reflexão, as características da Rota de Aprendizagem utilizada pode ter influenciado no desenvolvimento de reflexões além do nível descritivo. Pesquisas serão necessárias para um estudo aprofundado sobre a construção de atividades com enunciados que estimulem a reflexão em níveis crítico e metacrítico.

O portfólio torna-se um espaço para a reflexão sobre a prática vivenciada no estágio curricular, desde que tenha objetivos claros, seja bem compreendido por professores e estudantes e que estes sejam esclarecidos sobre suas principais características, sobre como deverá ser construído e avaliado.

As características do portfólio, quando bem utilizado, fazem dele um instrumento atual e coerente com as novas abordagens de educação, levando os sujeitos a conscientização de seu papel e da responsabilidade de encontrar caminhos para o desenvolvimento pleno de suas capacidades. 


\section{CONSIDERAÇÕES FINAIS}

Além da análise dos níveis de reflexão presentes nas narrativas, este estudo possibilitou a percepção de aspectos relacionados à vivência da prática pedagógica pelos licenciandos, que podem auxiliar no repensar o curso de licenciatura em enfermagem e o estágio curricular supervisionado, não só da EEUSP como de outras universidades.

Pode-se perceber que os licenciandos tiveram a oportunidade de vivenciar a prática pedagógica, aplicando os conteúdos abordados na teoria e refletindo sobre seu desempenho. Em relação às práticas em sala de aula, os licenciandos narraram suas facilidades e dificuldades, mostrando a grande importância dos conteúdos estudados na parte teórica das disciplinas do curso de licenciatura. Foi observado que muitos conteúdos foram assimilados e colocados em prática, mas outros talvez pudessem ser mais bem trabalhados.

Ficou evidente também a importância de um bom relacionamento entre a universidade e os campos de estágio. O licenciando relatou que se sentir acolhido e seguro, facilitou o desenvolvimento das competências desejadas para o estágio curricular supervisionado.

Os campos de estágio, escolas e instituições de saúde, poderiam estar mais bem preparados para receber o licenciando e oferecer recursos físicos e materiais para que ele consiga realizar as atividades propostas. A escolha dos campos prescinde de critérios bem estabelecidos, para que proporcione o desenvolvimento das competências desejadas para o estágio na licenciatura.

Os resultados mostram o papel importantíssimo do professor supervisor no desenvolvimento do estágio. O licenciando precisa ser considerado em todo seu contexto, enquanto estudante e pessoa, 
momento de vida, experiências anteriores, pois tais aspectos podem influenciar em sua aprendizagem e seu desempenho.

Deseja-se também, que o professor supervisor tenha formação para estar e se sentir mais preparado para o acompanhamento dos futuros professores em suas atividades. É importante que conheça os objetivos do curso e proporcione um ambiente acolhedor para o licenciando e que tenha consciência do seu papel enquanto facilitador na construção do conhecimento.

O licenciando sente a necessidade de exercitar sua autonomia, o que poderia ser proporcionado e estimulado pelo professor supervisor, além de preparar seus estudantes para receber o licenciando, explicitando a importância do estágio na formação do futuro professor.

É preciso refletir sobre a distribuição da carga horária do estágio em atividades realmente práticas, os licenciandos narraram sobre a influência do tempo para que se sentissem a vontade, se familiarizassem com o campo e iniciassem suas atividades de modo a realmente tornarem-nas significativas.

Tais considerações estimulam a novas pesquisas com o intuito de aprimorar os cursos de formação de professores.

Como diferencial deste estudo tem-se a elucidação da análise de narrativas em relação aos níveis de reflexão, contribuindo para que professores que trabalham com portfólios reflexivos tenham subsídios para analisarem a prática reflexiva de seus estudantes.

Assim como Paulo Freire (1996), "gosto de ser gente porque, inacabado, sei que sou um ser condicionado, mas, consciente do inacabamento, sei que posso ir mais além dele", e este trabalho traz 
inspiração para continuar a pesquisa na área, indo além, partindo agora para o doutorado. 
REFERÊNCIAS 


\section{REFERÊNCIAS}

Abrantes MMCBP. O desenvolvimento da reflexividade no contexto do discurso supervisivo. [Internet]. Aveiro: Universidade de Aveiro; 2005 [citado 2012 mar. 13]. Disponível em: http://biblioteca.sinbad.ua.pt/teses/2011000013

Alarcão I. Formação reflexiva de professores: estratégias de supervisão. Porto: Porto; 1996. Reflexão crítica sobre o pensamento de D. Schön e os programas de formação de professores; p. 9-39.

Alarcão I. Escola reflexiva e Nova racionalidade. Porto Alegre: Artmed; 2001.

Alarcão I. Professores reflexivos em uma escola reflexiva. $7^{a}$ ed. São Paulo: Cortez; 2010. (Coleção questões da nossa época, 8)

Alves LP. Portfólios como instrumento de avaliação dos processos de ensinagem. In: Alves, LP, Anastasiou, LGC, organizadores. Processos de Ensinagem na Universidade: pressupostos para estratégias de trabalho em aula. $6^{\underline{a}}$ ed. Joinville: UNIVILLE; 2006. p. 101-120.

Amaral J, Moreira MA, Ribeiro D. O papel do supervisor no desenvolvimento do professor reflexivo: estratégias de supervisão. In: Alarcão I. Formação reflexiva de professores: estratégias de supervisão. Porto: Porto; 1996. p. 91-122.

Amaral MJ. O papel dos "portfólios" reflexivos na formação complementar. In: Sá-Chaves I, organizadora. Os "portfólios" reflexivos (também) trazem gente dentro: reflexões em torno do seu uso na humanização dos processos formativos. Porto: Porto; 2005. p. 67-82.

Barreiro IMF, Gebran RA. Prática de Ensino e Estágio Supervisionado na Formação de Professores. São Paulo: Avercamp; 2006.

Bausola A. O pragmatismo. In: Rovighi SV. História da filosofia contemporânea: do século XIX a neoescolástica. $3^{\underline{a}}$ ed. São Paulo: Loyola; 2004. p. 459-72.

Bloom BS. Manual de avaliação formativa e somativa do aprendizado escolar. São Paulo: Pioneira; 1983.

Brasil. Decreto n. 2.208, de 17 de abril de 1997. Regulamenta o § 2 do art. 36 e os arts. 39 a 42 da Lei no 9.394, de 20 de dezembro de 1996, que estabelece as diretrizes e bases da educação nacional [legislação na Internet]. Brasília; 1997. [citado 2013 jan. 10]. 
http://www.planalto.gov.br/ccivil_03/decreto/D2208.htm

Brasil. Resolução CNE/CP 1, de 18 de fevereiro de 2002. Institui Diretrizes Curriculares Nacionais para a Formação de Professores da Educação Básica, em nível superior, curso de licenciatura, de graduação plena [Legislação na Internet]. Brasília; 2002. [citado 2012 abr. 10]. Disponível [em http://portal.mec.gov.br/seesp/arquivos/pdf/res1_2.pdf

Brasil. Resolução CNE/CEB n. 04, de 05 de outubro de 1999. Institui as Diretrizes Curriculares Nacionais para a Educação Profissional de Nível Técnico [legislação na Internet]. Brasília; 1999. [citado 2012 jun. 9]. Disponível em: http://portal.mec.gov.br/setec/arquivos/pdf/RCNE_CEB04_99.pdf

Carvalho AMP. Os Estágios nos Cursos de Licenciatura. São Paulo: Cengage Learning; 2012. (Coleção idéias em ação)

Carvalho MJS, Porto LS. Portfólio Educacional: proposta alternativa de avaliação - guia didático. Porto Alegre: UFRGS; 2005.

Coelho C, Campos J. O portfólio na sala de aula. Porto, Portugal: Areal Editores; 2003. (Coleção Como abordar...)

Conselho Federal de Enfermagem (COFEN). Lei n. 7498, de 25 de junho de 1986. Dispõe sobre a regulamentação do exercício da enfermagem e dá outras providências. [legislação na Internet]. Brasília; 1986. [citado 2012 ago. 5]. Disponível em: http://novo.portalcofen.gov.br/lei-n-749886-de-25-de-junho-de1986_4161.html

Conselho Federal de Enfermagem (COFEN). Resolução n. 299 de 16 de março de 2005. Dispõe sobre indicativos para a realização de estágio curricular supervisionado de estudantes de enfermagem de graduação e do nível médio [legislação na Internet]. Rio de janeiro; 2005. [citado 2012 mar. 16]. Disponível em: http://novo.portalcofen.gov.br/resoluo-cofen-2992005-revogada-pelaresoluo-cofen-n-3712010_4334.html

Conselho Federal de Enfermagem (COFEN). Resolução n. 371, de 08 de setembro de 2010. Dispõe sobre a participação do Enfermeiro na supervisão de estágio de estudantes dos diferentes níveis da formação profissional de Enfermagem. [legislação na Internet]. Brasília; 2010. [citado 2012 ago. 5]. Disponível em: http://novo.portalcofen.gov.br/resoluo-cofen-n-3712010_5885.html

Corrêa AK, Carvalho AMP, Silveira F, Souza MCBM, Nogueira MS. Formação docente em educação profissional técnica na área da saúde: experiência do NIAD USP/RP. In: Picciafuoco PRDF, 
coordenadora. Curso de formação docente: trabalhos de conclusão de curso. São Paulo: Fundap; 2011. p. 77-93.

Darsie MMP, Carvalho AMP. O início da formação do professor reflexivo. Revista da Faculdade de Educação de São Paulo [Internet]. 1996 [citado 2011 out. 20];22(2):90-108. Disponível em: http://educa.fcc.org.br/pdf/rfe/v22n2/v22n2a05.pdf

Dias CMS. "Portfólio" reflexivo: fragmentos de uma experiência. In: Sá-Chaves I, organizadora. Os "portfólios" reflexivos (também) trazem gente dentro: reflexões em torno do seu uso na humanização dos processos formativos. Porto: Porto; 2005. p. 109-118.

Flick U. Métodos de pesquisa: introdução à pesquisa qualitativa. Trad. de Joice Elias Costa. $3^{\underline{a}}$ ed. Porto Alegre: Artmed; 2009.

Fortuna CM, Gonçalves MFC, Silva MAI, Santos RA. A produção de narrativas crítico-reflexivas nos portfólios de estudantes de enfermagem. Revista da Escola de Enfermagem da USP [Internet]. 2012 [citado 2013 jan. 21];46(2):452-9. Disponível em: http://www.scielo.br/pdf/reeusp/v46n2/a25v46n2.pdf

Freire AM. Concepções orientadoras do processo de aprendizagem do ensino nos estágio pedagógicos. Colóquio: modelos e práticas de formação inicial de professores. Lisboa: Faculdade de Psicologia e de Ciências da Educação, Universidade de Lisboa; 2001. [citado 2012 mar. 14]. Disponível em: http://www.educ.fc.ul.pt/recentes/mpfip/pdfs/afreire.pdf

Freire P. Pedagogia do oprimido. $17^{\mathrm{a}}$ ed. Rio de Janeiro: Paz e Terra; 1987.

Freitas MAO, Cunha ICKO, Batista SHSS. O portfólio como instrumento de avaliação em cursos de Pós-graduação lato sensu. In: Anais do VIII EDUCERE - Congresso Nacional de Educação; 2008. p. 4684-94; Curitiba [Internet]. Curitiba: PUCPR; 2008. [citado 2011 nov. 14]. Disponível em: http://www.pucpr.br/eventos/educere/educere2008/anais/pdf/95_184. pdf

Frison LMB, Simão AMV. Abordagem (auto)biográfica - narrativas de formação e de autorregulação da aprendizagem reveladas em portfólios reflexivos. Educação (Porto Alegre) [Internet]. 2011 [citado 2012 mai. 15];34(2):198-206. Disponível em: http://redalyc.uaemex.mx/src/inicio/ArtPdfRed.jsp?iCve $=8481905801$ 0

Gardner $\mathrm{H}$. Inteligências múltiplas: a teoria na prática. Trad. de Maria Adriana Veríssimo Veronese. Porto Alegre: Artmed; 1995. 
Giovanni LM. Indagação e reflexão como marcas da profissão docente. In: Guarnieri MR, organizadora. Aprendendo a ensinar: o caminho nada suave da docência. $2^{\underline{a}}$ ed. Campinas (SP): Autores Associados; 2005. p. 45-59.

Grilo J, Machado C. "Portfólios" reflexivos na Formação inicial de Professores de Biologia e Geologia: viagens na terra do eu. In: SáChaves I, organizadora. Os "portfólios" reflexivos (também) trazem gente dentro: reflexões em torno seu uso na humanização dos processos educativos. Porto: Porto Editora; 2005. p. 21-49.

Hadji C. Avaliação Desmistificada. Trad. de Patrícia C. Ramos. Porto Alegre: Artmed; 2001.

Hoffmann J. Avaliar para promover: as setas do caminho. 9a ed. Porto Alegre: Mediação; 2006.

Lalanda MC, Abrantes MM. O conceito de reflexão em j. Dewey. In: Alarcão I, organizadora. Formação reflexiva de professores: estratégias de supervisão. Porto: Porto; 1996. p. 41-62.

Libâneo JC. Adeus professor, Adeus professora? Novas exigências educacionais e profissão docente. 6a ed. São Paulo: Cortez; 2002. (Série formação do professor).

Liberalli FC. O diário como ferramenta para a reflexão crítica [tese]. São Paulo: Pontifícia Universidade Católica de São Paulo; 1999.

Lobo Neto FJS. Ser professor: necessidade de formação profissional específica. Formação [Internet]. 2002 [citado 2012 jan. 12]; 2(4):5$13 . \quad$ Disponível em: http://bvsms.saude.gov.br/bvs/publicacoes/profae/Revista2004.pdf

Love D, McKean G, Gathercoal P. Portfolios to webfolios and Beyond: Levels of Maturation. Educause Quarterly [Internet]. 2004 [citado 2011 nov. 14];27(2):24-37. Disponível em: http://www.educause.edu/ero/article/portfolios-webfolios-and-beyondlevels-maturation

Madeira MZAI, Lima MGSB. A prática de ensinar: dialogando com as professoras de enfermagem. Revista Brasileira de Enfermagem (Brasília) [Internet]. 2008 [citado 2013 jan. 17];61(4):447-53. Disponível em http://redalyc.uaemex.mx/src/inicio/ArtPdfRed.jsp?iCve=2670196050 08

Moreira J. Portefólio do professor: o portefólio reflexivo no desenvolvimento profissional. Porto: Porto; 2010.

Motta MGC, Almeida MA. Repensando a licenciatura em enfermagem à luz das diretrizes curriculares. Revista Brasileira de 
Enfermagem [Internet]. 2003 [citado 2012 jun 14];56(4):417-419. Disponível em: http://www.scielo.br/scielo.php?pid=S0034$71672003000400023 \&$ script=sci_arttext

Nadal BG. Possibilidades para a formação de professores práticosreflexivos através de iniciativas de formação contínua: espaços de intersecção. In: Ribas MH, organizadora. Formação de professores: escolas, práticas e saberes. Ponta Grossa: UEPG; 2005. p.123-58.

Nóvoa A. Os professores e a sua formação. Lisboa: Dom Quixote; 1992.

Nóvoa A. Para uma formação de professores construída dentro da profissão. Revista Educación [Internet]. 2009 set-dez [citado 2013 jan. 08];350. Disponível em: http://www.revistaeducacion.mec.es/re350/re350_09por.pdf

Nunes A, Moreira A. O "portfólio" na Aula de Língua Estrangeira: uma forma de aprender a aprender e a ser (para alunos e professores). In: Sá-Chaves I, organizadora. Os "portfólios" reflexivos (também) trazem gente dentro: reflexões em torno seu uso na humanização dos processos educativos. Porto: Porto Editora; 2005. p. 51-66.

Oliveira MAC, Veríssimo MLÓR, Püschel VAA, Riesco MLG. Desafios da formação em enfermagem no Brasil: proposta curricular da EEUSP para o bacharelado em enfermagem. Revista da Escola de Enfermagem da USP [Internet]. 2007 [citado 2012 fev. 09];41(Esp):820-5. Disponível em: http://www.scielo.br/pdf/reeusp/v41nspe/v41nspea13.pdf

Pereira ASF. O ensino clínico de enfermagem médico-cirúrgica: contributo do feedback na promoção de competências autoregulatórias dos futuros enfermeiros [Internet]. Lisboa: Faculdade de Psicologia e de Ciências da Educação, Universidade de Lisboa; 2008 [citado 2011 nov. 14]. Disponível em: http://repositorio.ul.pt/bitstream/10451/804/1/16851_Ensino\%2520Cli nico\%2520Enfermagem\%2520MCcontributo\%2520do\%2520feedback.PDF

Pimenta SG. Professor reflexivo: construindo uma crítica. In: Pimenta SG, Ghedin E, organizadores. Professor reflexivo no Brasil: gênese e crítica de um conceito. $3^{\underline{a}}$ ed. São Paulo: Cortez; 2005. p. 17-52.

Pimenta SG. O Estágio na Formação de Professores: Unidade teoria e prática? 11ํㅡㄹ ed. São Paulo: Cortez; 2012.

Prado C, Martins CP, Alavarce DC. Ferramentas tecnológicas no ensino de enfermagem: um universo de possibilidades pedagógicas. In: Prado C, Peres HHC, Leite, MMJ. Tecnologia da Informação e da 
Comunicação em Enfermagem. São Paulo: Atheneu; 2011. p. 103112.

Püschel VAA. A mudança curricular do bacharelado em Enfermagem da Escola de Enfermagem da USP: análise documental e vivência dos participantes. [tese livre-docência]. São Paulo: Escola de Enfermagem, Universidade de São Paulo; 2011.

Püschel VAA, Sigaud CHS, Oliveira MAC, Veríssimo MLÓR, Riesco MLG. Projeto Pedagógico Bacharelado em Enfermagem. São Paulo: EEUSP; 2009. (Projeto Pedagógico)

Ramos MA, Gonçalves RE. As narrativas autobiográficas do professor como estratégia de desenvolvimento e a prática da supervisão. In: Alarcão I, organizadora. Formação reflexiva de professores: estratégias de supervisão. Porto: Porto; 1996. p. 123150.

Rampazzo L. Metodologia científica. 3를 ed. São Paulo: Loyola; 2005.

Reis LG. Produção de monografia da teoria à prática: o método educar pela pesquisa (MEP). $3^{a}$ ed. Brasília: Senac; 2010.

Sá-Chaves ISC. Portfólios reflexivos: estratégia de formação e de supervisão. Aveiro: Universidade de Aveiro; 2000. (Cadernos didácticos, Série Supervisão, 1).

Sá-Chaves ISC. A construção de conhecimento pela análise reflexiva da práxis. Coimbra: Fundação Gulbenkian e Fundação Para a Ciência e a Tecnologia; 2002.

Sá-Chaves ISC, organizadora. Os "portfólios" reflexivos (também) trazem gente dentro: reflexões em torno seu uso na humanização dos processos educativos. Porto: Porto Editora; 2005.

Sadalla AMFA, Sá-Chaves ISC. Constituição da reflexividade docente: indícios de desenvolvimento profissional coletivo. Educação Temática Digital [Internet]. 2008 jun [citado 2012 out 17];9(2):189203. Disponível em: http://educa.fcc.org.br/scielo.php?pid=S167625922008000200016\&script=sci_arttext

Santos CR, organizador. Avaliação educacional: um olhar reflexivo sobre a sua prática. São Paulo: Avercamp; 2005.

Santos E. Portfólio e cartografia cognitiva: dispositivos e interfaces para a prática da avaliação formativa em educação online. In: Silva $M$, Santos $E$, organizadores. Avaliação da aprendizagem em educação online. São Paulo: Loyola; 2006. p. 315-331.

Santos V, Candeloro RJ. Trabalhos acadêmicos: uma orientação para a pesquisa e normas técnicas. Porto Alegre (RS): AGE; 2006. 
Sá-Silva JR, Almeida CD, Guindani JF. Pesquisa documental: pistas teóricas e metodológicas. Revista Brasileira História \& Ciências Sociais [Internet]. 2009 jul. [citado 2011 abr. 10]; 1(1). Disponível em:

http://rbhcs.com/index_arquivos/Artigo.Pesquisa\%20documental.pdf

Schön DA. Educando o Profissional Reflexivo: um novo design para o ensino e a aprendizagem. Trad. de Roberto Cataldo Costa. Porto Alegre: Artmed; 2000.

Schneider El, Medeiros LF, Urbanetz ST. O Aprender e o Ensinar em EAD por meio de Rotas de Aprendizagem. In: Anais do 15은 Congresso Internacional da ABED de Educação a Distância; 2009; Fortaleza [Internet]. Fortaleza: ABED; 2009. [citado 2011 nov 16]. Disponível em: http://www.abed.org.br/congresso2009/CD/trabalhos/155200917453 4.pdf

Shores E, Grace C. Manual de portfólio: um guia passo a passo para o professor. Trad. de Ronaldo Cataldo Costa. Porto Alegre: Artmed; 2001.

Shulman LS. Conocimiento y enseñanza: fundamentos de La nueva reforma. Profesorado. Revista de currículum y formación del profesorado [Internet]. 2005. [citado 2013 jan. 20];9(2). Disponível em: http://www.ugr.es/ recfpro/rev92ART1.pdf

Sigaud CHS, Oliveira MAC, Veríssimo MLÓR, Riesco MLG, Püschel VAA. Projeto Político Pedagógico Licenciatura em Enfermagem. São Paulo: EEUSP; 2011. (Projeto Político Pedagógico)

Silva CMSLMD, Tanji S. O portfólio reflexivo: pareceres dos estudantes de enfermagem. Revista Iberoamericana de Educação (Rio de Janeiro) [Internet]. 2008 [citado 2011 nov. 14];46(6):1-10. Disponível em: http://www.rieoei.org/deloslectores/2070Monteiro.pdf

Silva NRG. Estágio supervisionado em pedagogia. Campinas (SP): Alínea; 2011.

Silva RF, Sá-Chaves I. Formação reflexiva: representações dos professores acerca do uso de portfólio reflexivo na formação de médicos e enfermeiros. Interface (Botucatu) [Internet]. 2008 [citado 2012 abr. 15];12(27):721-734. Disponível em: http://www.scielo.br/scielo.php?script=sci_arttext\&pid=S1414$32832008000400004 \& \operatorname{lng}=$ en

Simões JFFL, Alarcão, I, Costa N. Supervisão em ensino clínico de enfermagem: a perspectiva dos enfermeiros cooperantes. Revista Referência [Internet]. 2008 [citado 2012 out 25];II(6):91-108. 
Disponível

em:

http://www.index-

f.com/referencia/2008pdf/0691108.pdf

Simões JFFL, Garrido AFS. Finalidade das estratégias de supervisão utilizadas em ensino clínico de enfermagem. Texto e Contexto em Enfermagem [Internet]. 2007 [citado 2013 jan. 23];16(4):599-608. Disponível

http://www.scielo.br/pdf/tce/v16n4/a03v16n4.pdf

Stutz BL, Jansen AC. Ensino técnico na área da saúde: os desafios do processo de aprendizagem. Psicologia Escolar e Educacional [Internet]. 2006 [citado em 2013 jan. 17];10(2):211-221. Disponível em: http://www.scielo.br/scielo.php?script=sci_arttext\&pid=S1413$85572006000200005 \&$ lng $=\mathrm{pt}$

Tardif M. Saberes profissionais dos professores e conhecimentos universitários: Elementos para uma epistemologia da prática profissional dos professores e suas conseqüências em relação à formação para o magistério.

Revista Brasileira de Educação [Internet]. 2000 [citado 2012 out. 20];(13):5-13. Disponível em: http://educa.fcc.org.br/pdf/rbedu/n13/n13a02.pdf

Tomaz ACTVLBF. Supervisão curricular e cidadania: novos desafios à formação de professores. [Internet]. Aveiro: Universidade de Aveiro; 2007 [citado 2012 mar 17]. Disponível em: http://ria.ua.pt/bitstream/10773/1456/1/2008001363.pdf

Valente GSC. A formação do enfermeiro para o ensino de nível médio em enfermagem: uma questão de competências. [Internet]. Rio de Janeiro: Escola de Enfermagem Anna Nery, Universidade Federal do Rio de Janeiro; 2005 [citado 2013 jan. 21]. Disponível em: http://teses.ufrj.br/EEAN_m/GeilsaSoraiaCavalcantiValente.pdf

Valente GSC, Viana LO. La formación del enfermero para la enseñanza de nivel medio en enfermería: una cuestión de competencias. Enfermería Global. 2006; 5(2):1-8. Disponível em: http://revistas.um.es/eglobal/article/view/364

Vasconcellos CS. Avaliação: concepção dialética-libertadora do processo de avaliação escolar. São Paulo: Libertad; 2000.

Vaz DR, Prado C, Almeida DM, Heimann C, Lopes TO. Portfólio Reflexivo Educacional: construção de aula virtual para licenciandos de enfermagem. In: XI Conferência Iberoamericana de Educação em Enfermagem; 2011 set. 18-24; Coimbra [Internet]. Coimbra (PT): ALADEFE; 2011. [citado 2013 mar. 02]. Disponível em: http://www.aladefe2011.com/event/event/abstracts/index.php?target $=$ list-abstract - presentations\&event $=64 \&$ defLang=4\&action=search 
Villas Boas BMF. Portfólio, avaliação e trabalho pedagógico. $5^{\text {a }}$ ed. São Paulo: Papirus; 2008. Situando o portfólio; p. 37-104.

Zeichner KM. A formação reflexiva de professores: ideias e práticas. Lisboa: EDUCA; 1993.

Zeichner KM. Formando professores reflexivos para a educação centrada no aluno: possibilidades e contradições. In: Barbosa RLL, organizadora. Formação de educadores: desafios e perspectivas. São Paulo: Unesp; 2003. p. 35-56.

Zeichner KM, Liston DP. Teaching Student Teachers to Reflect. Harvard Educational Review. 1987;56(1):23-48.

Zuin PB, Zuin LFS. Analisando documentos e outros materiais. In: Reyes CR, Monteiro HM. Um olhar crítico-reflexivo diante da realidade educacional. São Carlos: EdUFSCar; 2010. p. 65-80. 
APÊNDICE 


\section{APÊNDICE A - ROTA DE APRENDIZAGEM}

\section{1 - RECOMEÇANDO A DISCIPLINA}

- Ao cursar a disciplina de Metodologia I você deve ter encontrado aspectos facilitadores e dificultadores de sua aprendizagem. Analisando seu desempenho até o momento, faça um breve relato das estratégias (pessoais e acadêmicas) que utilizará para ampliar seu conhecimento na disciplina de Metodologia II.

- Para esta atividade não será atribuída nota.

2 - RECONHECIMENTO DA ESCOLA - CAMPO DE PRÁTICA $(1,0)$

a) Descrição da escola: Faça uma descrição detalhada do campo de prática apresentando os recursos físicos, humanos e materiais identificados. Aponte elementos que poderão ser facilitadores e/ou dificultadores do planejamento e da implementação do seu estágio. $(0,5)$

b) Caracterização dos alunos - descreva e contextualize características dos alunos de sua escola campo de estágio. $(0,5)$

3 - DESCRIÇÃO REFLEXIVA DA AULA TEÓRICA ASSISTIDA $(2,0)$

Após assistir a aula teórica do professor do seu campo de estágio:

a) Preencha o "Roteiro de observação de aula teórica" - imprima e entregue na secretaria do ENO. $(0,5)$

b) A ppartir do "Roteiro de observação de aula teórica", faça uma breve análise da aula assistida quanto aos itens sensibilização para a aula; desenvolvimento da aula e encerramento, a postura do professor, a estratégia utilizada e a avaliação da aula. $(1,5)$

4 - DESCRIÇÃO REFLEXIVA DA AULA TEÓRICA MINISTRADA $(3,0)$

a) Plano de aula - anexe seu plano de aula. $(0,5)$

b) Analise os tópicos abaixo relacionados ao seu Plano de aula: 
- Tema da aula: qual o critério utilizado para a escolha do tema de sua aula.

- Objetivos educacionais e conteúdos: descreva como esses itens foram planejados; aponte qual concepção pedagógica foi adotada considerando as características dos alunos, já identificadas. $(0,5)$

- Organização do tempo: descreva e justifique o tempo que utilizará para cada parte de sua aula. $(0,5)$

- Estratégias de ensino: descreva sua estratégia de ensino e explique sua relação com o público-alvo, com os objetivos e conteúdos propostos. $(0,5)$

- Processo de avaliação: relate que estratégias você utilizou para verificação da aprendizagem dos alunos a curto, médio e/ou longo prazo e se utilizou algum instrumento ou estratégia de avaliação de sua aula - anexe se necessário. $(0,5)$

- Reflexão sobre essa experiência: Faça uma breve reflexão sobre essa experiência, destacando aspectos positivos, negativos e/ou outros comentários que acharem pertinentes. Descreva o que você faria para melhorar suas próximas aulas. $(0,5)$

\section{5 - DESCRIÇÃO REFLEXIVA DA AULA DE LABORATÓRIO ASSISTIDA}

- Reflexão sobre essa experiência: Faça uma breve reflexão sobre essa experiência, destacando aspectos positivos, negativos e/ou outros comentários que achar pertinentes. Se você fosse ministrar essa mesma aula, o que você faria para melhorá-la?

- Para esta atividade não será atribuída nota.

6 - DESCRIÇÃO REFLEXIVA DA AULA DE LABORATÓRIO MINISTRADA

- Reflexão sobre essa experiência: Faça uma breve reflexão sobre essa experiência, destacando aspectos positivos, 
negativos e/ou outros comentários que achar pertinentes. Se você fosse ministrar essa mesma aula, o que você faria para melhorá-la?

- Para esta atividade não será atribuída nota.

7 - DESCRIÇÃO REFLEXIVA DA SUPERVISÃO EM CAMPO DE PRÁTICA $(3,0)$

- Relate sua experiência como licenciando/supervisor de estágio, no hospital e/ou UBS - campo de prática, pontuando as facilidades e dificuldades encontradas no acompanhamento e avaliação dos alunos. $(1,5)$

- Descreva seu relacionamento interpessoal com alunos e professores da escola - campo de estágio e com os funcionários, pacientes e familiares do hospital e/ou UBS campo de estágio. $(1,5)$

\section{8 - FINALIZANDO A EXPERIÊNCIA DA DISCIPLINA $(1,0)$}

- Fale sobre sua percepção a respeito da importância e contribuição da parte teórica da disciplina na sua formação pessoal e como futuro professor de enfermagem. Relate os sentimentos vivenciados e proponha sugestões para melhoria das aulas para os futuros licenciandos de enfermagem. $(0,5)$

- Fale sobre sua percepção a respeito da importância e contribuição do estágio na sua formação pessoal e como futuro professor de enfermagem. Relate os sentimentos vivenciados e proponha sugestões para melhoria do estágio para os futuros licenciandos de enfermagem. $(0,5)$

- Para esta atividade não será atribuída nota.

Lembre-se: ao terminar cada tarefa você deverá postá-la no Moodle. 
ANEXOS 
ANEXO 1 - PARECER CONSUBSTANCIADO DO CEP

\author{
ESCOLA DE ENFERMAGEM DA \\ UNIVERSIDADE DE SÃO \\ PAULO - EEUSP
}

\title{
PARECER CONSUBSTANCIADO DO CEP
}

\section{DADOS DO PRONETO DE PESGUISA}

Titulo da Peqqu/sa: AVALIACAO DA FORMACAO DOCENTE EM ENFERMAGEM NA PEFSPECTMA DE DOCENTES E DE LICENCIANDOS

Peequlsador: claudla Frado

Area Tematica:

Vereas: 2

CAAE: 08665612.50000 5392

Institulça Proponante: Esola de Entemagenn da Unversidade de sto Paulo - EEuSF

\section{DADOS DO PARECER}

Nümero do Parecer: 145091

Data da Relatorla: $13 / 11 / 2012$

Apreentapao do Projeto:

O projeb propozese a aval ar o ensino de mojdulos do curso de lcenclatura em entemagen que utllza a tenolugla de amblente virtual cono ferramenta de ensho. A avalac ja jo possbilta o aprimoramento do curso, que tem como finaldade a formacia co de llonclandos de entemagem para se tomarem próesecres

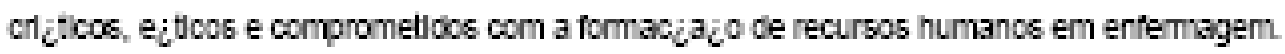

o curso de lbenclatura em enfemagem da EEUSP ten sido processualmente avalado pelos Ilcenclandos.

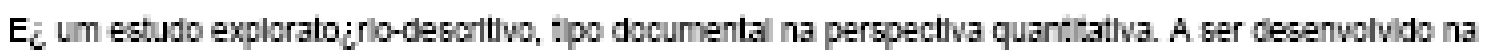
Escola de Enfermagen da USP.

Fara o 10 objetvo: bera; a anal sados documentos relaclonados ao processo ensino-aprendlzagem, utllzados por docentes e d scentes, nas dlscip inas ENO 435 - Metodologla de Ensino em Enfemagem I e ENO 436 - Metodologla de Ensino em Entermagem II, Inclulndo os dlsponizvels na plataforma Moode, nos anos de 2009 a 2013

Sera;o anal sados instrumentos construl; ¿do6 para a avallacjajo do processo ensino-aprendlzagem em aulas viruals, bem como a planilha de notas parclals totals.

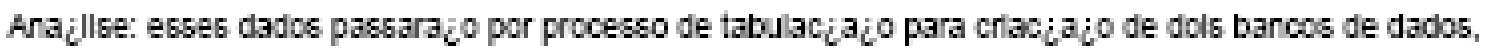
um no progana spss for Wndows (Statste Package for Soclal Sclences) e um no programa Exel, ambos. para processanento estal. ¿ation.

6

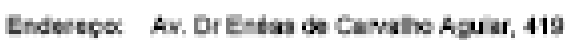

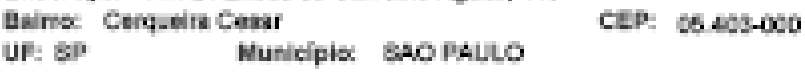

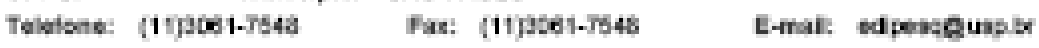




\section{ESCOLA DE ENFERMAGEM DA UNIVERSIDADE DE SÃ̃O PAULO - EEUSP}

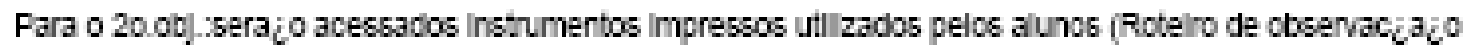
de aula teo crica assistida; Instrumento de avalaciaco do plano de aula; Instrumento de avalaciaco da

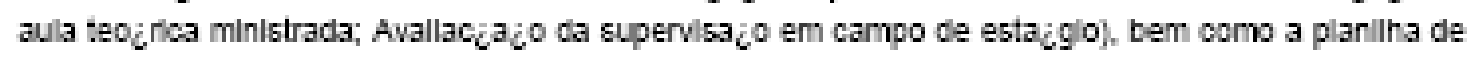
notas parclals e totals. Anajilse serai felta em relacia $a_{i} 0$ a 55 notas dos professores de campo de estaiglo nessas attvidades, das notas dos alunos (auto avallaciajo), da me $i d l a$ das notas e dos comentairios expicitados em cada instrumento. Para 0 30. objebivo: seraç acessados os webfo illos na Plataforma Moodle e a disciplina ENO 435 - Metodologla de ensino em enternagem II referentes ao ano de 2011. Para 040 . objesvo sera; 0 analsados instrumentos de avallaci $a_{i}$ ¿ das disciplinas ENO 435 - Metodologla do Ensino de enfermagem I e ENO 436 - Metodologla do Ensino de Enfermagem II, reterentes a ano de 2011, que foram preenchidos pelos licenclandos ao final de cada uma delas.

O instrumento conte im 60 questo $i$ es contemplando questo $i e s$ referentes aos objetlvos, conteuidos e estrate $i g l a s$ e mecanimos de avalaciajo da aprendlzagem, ao campo de esta $i g l o$ e ao uso do antlente vitual aprendzagem adotada na disciplina.

Objativo da Pesquisa:

Cojettivo Gerat:

Avallar a fomaciaico docente em entermagem na perspectiva de docentes e de llcenclados.

Cojettwo Especlicfloos:

1- Descrever a anallsar o processo de avallaciajo da aprendizagem nas aulas virtuals das discipinas Metodologla do Ensino de Enfermagen I e II.

2- Avallar a aprendizagem de licenclandos de entemagem nas duterentes etapas do Estacglo Curricular Supervisionado

3- Analsar o Webto jllo como instrumento de avallaciajio no Esta iglo Curricular Supenvisionado quanto ao seu potencial para o desenvolvinento da capacidade de reflexaco do aluno.

4- Avalar a fomaciacio docente em entemagem na perspectiva de licenclandos de entermagem

Avallaça dos Riscos $\theta$ Benaficloe:

Riscos: a pesquisa najo oferece riscos.

Beneficlos: aprimoramento da formaçăbo de enfermelros docentes, com consequente aprimoramento da formaçăo do pronssional de nlvel medlo em enfermagem, refletindo na qualldade da asslste ¿ncla e do ensino de entermagem.

Comentarice $\Theta$ Consideraçరes sobre a Pesqulsa:

O projeto esta multo bem delineado, fundannentado e $c 0 m$ viabllidde para responder 05 objeltivos propostos. Os resultados da pesquisa poderăo, certamente, contribulr para o aperfelçcamento do curso de Licenclatura em Entermagem e, consequentemente, da formaci $a_{i}{ }_{0}$ pedago $i g l c a$ do enfermelro.

Endersçex. Ax, Or Entas de Carvalhe Rauar, 419

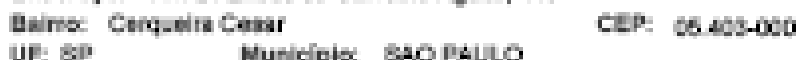

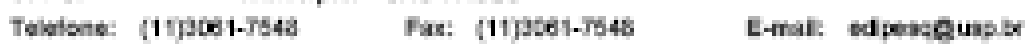




\section{ESCOLA DE ENFERMAGEM DA UNIVERSIDADE DE SÃO PAULO - EEUSP}

Considarap̧ese sobre os Termos de apresentaga obrlgatorla:

Fresdrde de TCLE, pols trata-se de ana illse documental.

A pequlsadora uillzara banos de dados, $00 \mathrm{~m}$ resultados de arallackes tel.as por estudartes. Infomou que os estudantes autorlzaram a utllzaçăo deseas avallaçles para pesqulsa e tambem que codiflcara as. avallaçes de torma a Impoesbiliar a Ident Alcacto dos mesmos.

Rocomendaços:

Recomenda-se a dhulgac iaco dos resultados da pequlla.

Conclusbas ou Pandenclase Llsta de Inadequapoe:

o projeto năo apresenta dolces eticos.

Sttuçso do Parecar:

Aprovado

Noceselta Apreclacso da CONEP:

No5

Considarap̧oes Finale a crtterlo do CEP:

SAO PAJLO, 13 de Noventor de 2012

Aaslnador por:
Calla Marla Slwall Campos
[Coordanador]

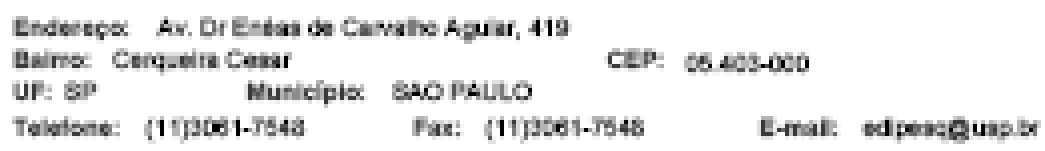

